\title{
Article
}

\section{Enrichment of rare earth elements (REE) in granitic rocks and their weathered crusts in central and southern Laos}

\author{
Kenzo Sanematsu ${ }^{1}$, Hiroyasu Murakami ${ }^{1}$, Yasushi Watanabe ${ }^{1}$, \\ Sixomxeun Duangsurigna ${ }^{2}$ and Siphandone Vilayhack ${ }^{2}$
}

\begin{abstract}
Kenzo Sanematsu, Hiroyasu Murakami, Yasushi Watanabe, Sixomxeun Duangsurigna and Siphandone Vilayhack (2009) Enrichment of rare earth elements (REE) in granitic rocks and their weathered crusts in central and southern Laos. Bull. Geol. Surv. Japan, vol.60(11/12), p.527-558, 8 figs, 2 tables, 2 appendixes.
\end{abstract}

\begin{abstract}
This paper reports geochemical characteristics of granitic rocks and enrichment of rare earth elements (REE) in their weathered crusts in central and southern Laos in order to assess a REE resource potential of ion-adsorption type mineralization. The granitic rocks in the studied area consist mainly of biotite \pm hornblende granodiorite and biotite granite with low to moderate total REE contents with the range of $36-339 \mathrm{ppm}$. The granitic rocks are enriched in light REE (LREE) with the depletion of heavy REE (HREE) compared with HREE-enriched granites in southern China and southwest Japan. This difference in the enrichment of HREE is probably derived from poor differentiation of magma for granite. Weathered crusts of the granitic rocks are generally well developed and rich in kaolin and illite. The weathered crusts can be divided into the $\mathrm{A}, \mathrm{B}$ and $\mathrm{C}$ horizons from top to bottom and the B horizon is enriched in REE relative to the parent rocks whereas the A and C horizons are generally depleted or less enriched in REE. Weathered crusts with relatively high REE contents are locally identified in the Attapu and Xaisomboun districts. Geochemical data and results of sequential leaching suggest that the enrichment of REE is attributed to the occurrence of ion-exchangeable clay minerals and REE phosphates in the weathered crusts and that HREE are selectively adsorbed on the clay minerals than LREE by weathering.
\end{abstract}

Keywords: Rare earth elements (REE), granitic rocks, weathered crust, ion-adsorption type mineralization, Laos

\section{Introduction}

In recent years, a relationship between demand and supply of rare earth elements (REE) resources has been becoming tight in the world market (Roskill, 2007). Especially, prices of heavy rare earth elements (HREE: $\mathrm{Gd}-\mathrm{Lu}$ ) have been dramatically increased compared with those of light rare earth elements (LREE: $\mathrm{La}-\mathrm{Eu}$ ) (Industrial Rare Metals, 2008). This problem results from not only the increase in the demand of HREE but also the limited supply of HREE from ore deposits. In the present day, HREE resources are produced mostly from ion-adsorption type REE deposits in the Longnan district, southern China. The ion-adsorption type deposits are formed by chemical weathering of granitic rocks and subsequent chemical adsorption of REE on kaolinite and halloysite (Yang et al., 1981; Ishihara and Sato, 1982; Huang et al, 1989; Wu et al.,
1990; Murakami and Ishihara, 2008). These deposits are characterized by one to five times condensation of REE in weathered crusts relative to the parent rocks and easy recovery of REE from the clayish ores by weak acids (Wu et al., 1990; Ban and Zhao, 2008). Average REE contents of the ion-adsorption ores range from 300 to $2000 \mathrm{ppm}$ approximately and vary depending on the parent rocks (Wu et al., 1996; Bao and Zhao, 2008; Murakami and Ishihara, 2008). Bao and Zhao (2008) showed that the parent rocks of the weathered crusts are I-type and S-type granitic rocks with some A-type granitic rocks, and are classified mainly into ilmenite-series. Most of these granitic rocks are characterized by biotite \pm muscovite mineral assemblages with K-feldspar phenocrysts (Huang et al., 1989). In southwest Japan, fractionated ilmenite-series granite is rich in REE, Sn and $\mathrm{W}$, and the enrichment of HREE is remarkable compared with LREE (Ishihara

\footnotetext{
${ }^{1}$ Institute for Geo-Resources and Environment, Geological Survey of Japan, AIST

${ }^{2}$ Department of Geology, Ministry of Energy and Mines, Lao P.D.R

Corresponding author: K. Sanematsu, Central7, 1-1-1 Higashi, Tsukuba, Ibaraki 305-8567, Japan. Email: k-sanematsu@aist.go.jp.
} 
and Murakami, 2006). Highly fractionated ilmeniteseries granite is generally related to $\mathrm{Sn}$ mineralization (e.g., Lehmann and Mahawat, 1989; Cerny et al., 2005). Thus, it is important to investigate the granite exposed in tropical or subtropical regions, where chemical weathering actively occurs, in order to discover promising ion-adsorption type REE mineralization.

In Vientiane, Lao Peoples Democratic Republic (Laos), the annual average temperature is $27^{\circ} \mathrm{C}$ and the annual precipitation is about $1834 \mathrm{~mm}$ (FAO, 2003). This warm and moist climate accelerates chemical weathering of granitic rocks in Laos. Ilmenite-series granitic rocks associated with $\mathrm{Sn}$ deposits are distributed extensively in central and southern Laos (DGM, 1991). This study explores a possibility of ion-adsorption type REE mineralization and the potential of REE resources in central and southern Laos by investigating REE contents of granitic rocks and weathered crusts on them.

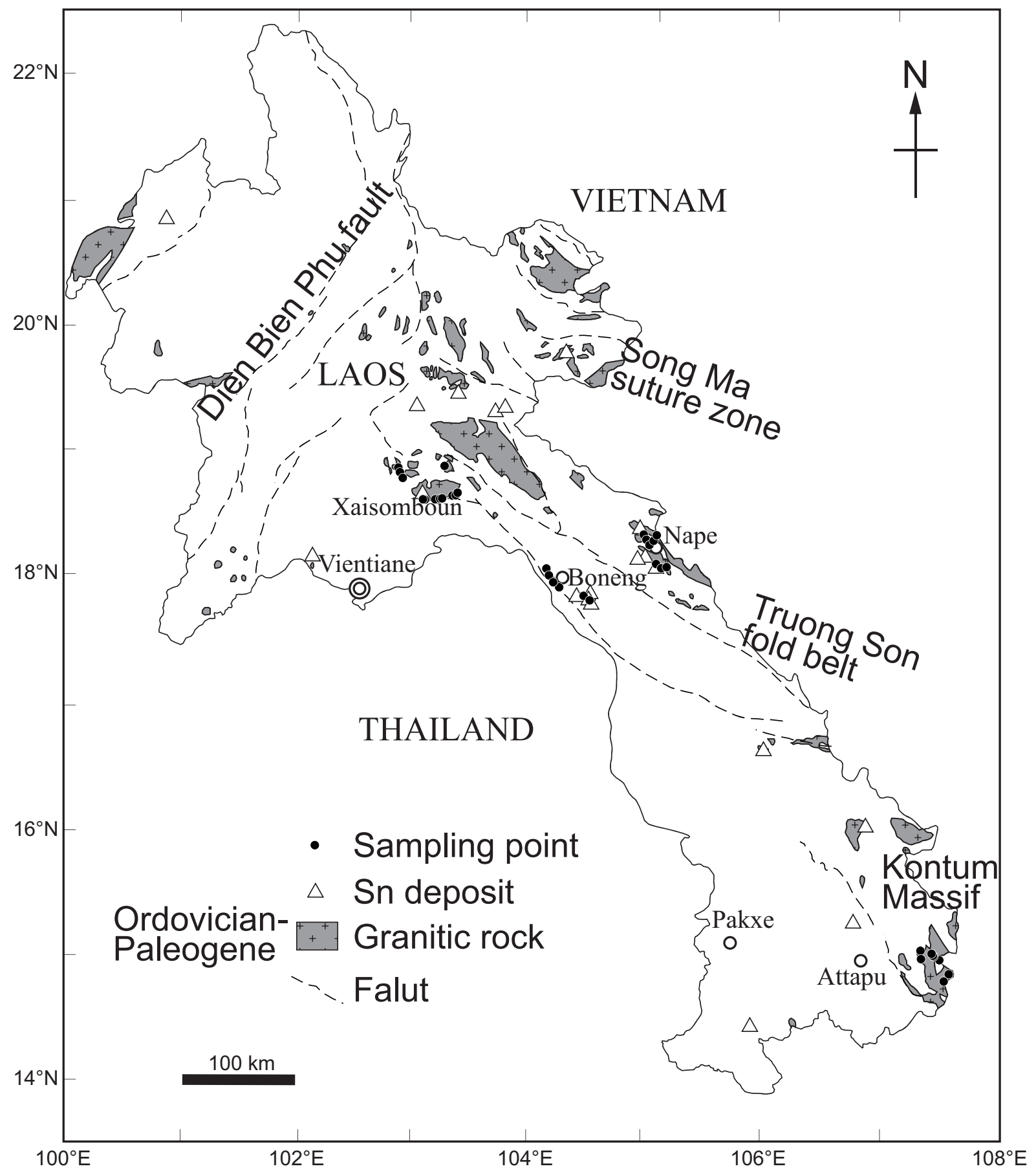

Fig. 1 Simplified geologic map showing the distribution of granitic rocks and sampling points in Laos. Modified from ESCAP (1990), DGM (1991) and Osanai et al. (2008). 


\section{Geological Settings}

The geology of Laos is basically divided into the northwestern Shan Thai block and southeastern Indoshina craton by the NE-SW trending Dien Bien Phu Fault (Fig. 1; ESCAP, 1990; DGM, 2000). The Shan Thai block is believed to have detached from the Indochina craton during $240-220 \mathrm{Ma}$ (Ferrari et al., 2008). The Indochina craton consists of several zones of basement metamorphic rocks such as the Redriver zone, Song Ma zone, Truong Son belt and Kontum Massif, which are cut by NW-SE trending shear zones (e.g., Hutchison, 1989; ESCAP, 1990; Osanai et al., 2008). Subduction-related volcanic activities are considered to have occurred from Permian to Triassic terranes in northern Laos. The volcanic rocks are composed of andesite and dacite with a small amount of basalt. The intrusive rocks widely distributed in Laos are mostly granodiorite and granite and they are believed to be Devonian to Jurassic in age, although few age data have been reported (ESCAP, 1990; Vilayhack et al., 2008). The ilmenite-series granitic rocks in central and southern Laos are commonly associated with $\mathrm{Sn} \pm$ W mineralization, which occurs as lateritic placer Sn deposits such as the Boneng and Nam Pathene deposits (DGM, 1991). In the southeasternmost of Laos, there are few Sn deposits within granitic rocks in the Kontum Massif, whereas $\mathrm{Cu} \pm \mathrm{Au}$ mineralization is recognized (Vilayhack et al., 2008). Owada et al. (2007) classified the granitic rocks in the Kontum Massif of Vietnam into garnet-bearing granite and orthopyroxene-bearing granite and argued that they are derived from the partial melting of pelitic gneisses and garnet-bearing mafic granulites, respectively.

\section{Sample description}

\subsection{Description of the granitic rocks}

The studied areas in the Truong Son fold belt and Kontum Massif in central and southern Laos are classified into the Attapu, Boneng, Nape and Xaisomboun districts (Fig. 1), and totally 29 least weathered granitic rock samples were collected. Granitic rocks in the east of Attapu are collected from the Xe Xou North and Xe Xou East Plutons (Vilayhack et al., 2008) in the Kontum Massif. The Xe Xou North Granodiorites are foliated and mylonitic in the eastern margin of the pluton, and the Xe Xou East Granites represent locally melanoclatic and heterogeneous facies (Vilayhack et al., 2008). The granitic rocks of the Boneng district were probably collected from Say Phou Ngou Pluton, which is situated in northwest of Thakhek (DGM, 2000). This pluton is classified into the Triassic porphyry accompanied with volcanic rocks and biotite granite with aplitic dykes (DGM, 1991). The granitic rocks of the Nape district is collected from the Nape Pluton (DGM, 2000), located near the border between Laos and Vietnam. They are accompanied with some aplitic and pegmatitic dykes and $\mathrm{Au}-\mathrm{Sn}-\mathrm{W}$ mineralization (DGM, 2000). In the Xaisomboun district, the samples were taken from different plutons in the northeast of Vientiane. Collected granitic rocks are mostly calcalkaline biotite \pm hornblende granodiorite, biotite granite and biotite granite porphyry (Table 1; Fig. 2A). They are composed of plagioclase, $\mathrm{K}$-feldspar, quartz, biotite and hornblende with small amounts of accessory minerals. Opaque minerals are mainly ilmenite, hematite and pyrite whereas magnetiteseries granitic rocks contain magnetite. Plagioclase and

Table 1 Petrography of representative granitic rock sample.

\begin{tabular}{|c|c|c|c|c|c|c|c|c|c|c|c|c|c|c|c|c|c|c|c|c|}
\hline Sample \# & District & Texture & Deformation & $\begin{array}{c}\text { Grain size } \\
(\mathrm{mm})\end{array}$ & $\begin{array}{c}\text { Kfs } \\
\text { megacryst }\end{array}$ & Qtz & Plg & $\mathrm{Kfs}$ & $\mathrm{Bt}$ & $\mathrm{Hbl}$ & Ms & Tur & Apt & Zir & Mnz & Xen & Aln & Tit & Alm & Thr \\
\hline P712 & Attapue & Equig. & & $0.6-4$ & & + & + & + & + & & & & + & + & & & & & & \\
\hline P725 & Attapue & Equig. & & $0.8-2.6$ & + & + & + & + & + & + & & & + & + & & & & + & & \\
\hline P726 & Attapue & Equig. & & $0.5-3$ & & + & + & + & + & & & & + & + & & & + & + & & + \\
\hline P793 & Attapue & Equig. & Foliated & $1-3$ & + & + & + & + & + & + & & & + & + & & & + & + & & + \\
\hline 62701 & Boneng & Equig. & & $0.2-2$ & & + & + & + & + & & & & + & + & + & + & & & & \\
\hline 62702 & Boneng & Porph. & & $0.05-0.25$ & + & + & + & + & + & & & & + & + & + & + & + & & & \\
\hline 62802 & Boneng & Equig. & & $1-3$ & & + & + & + & + & & & & + & + & & & & & + & \\
\hline 62809 & Boneng & Porph. & & $0.1-0.25$ & + & + & + & + & + & & & & + & + & & & + & & + & + \\
\hline 62814 & Boneng & Equig. & & $0.3-2.5$ & & + & + & + & + & & & + & + & + & + & & & & + & \\
\hline 62901 & Nape & Equig. & & $1-5$ & & + & + & + & + & & & & + & + & + & + & + & & & \\
\hline 62903 & Nape & Equig. & & $0.8-5$ & & + & + & + & + & & & & + & + & + & & & & & \\
\hline 63001 & Nape & Equig. & & $1-4$ & & + & + & + & + & & $+?$ & & + & + & + & & & & & \\
\hline 63002 & Nape & Equig. & & $1-3$ & & + & + & + & + & & & & + & + & + & + & & & & \\
\hline 63005 & Nape & Equig. & & $1-4$ & & + & + & + & + & & & & + & + & + & & & & & \\
\hline 70101 & Nape & Equig. & & $1-4$ & + & + & + & + & + & & & & + & + & + & + & & & & \\
\hline 70102 & Nape & Equig. & & $1-3$ & + & + & + & + & + & & & & + & + & + & & & & & \\
\hline 70105 & Nape & Porph. & & $0.2-0.5$ & + & + & + & & + & & & & + & + & + & & + & & & \\
\hline 70107 & Nape & Equig. & & $0.5-2$ & + & + & + & + & + & & & & + & + & + & & & & & \\
\hline 70108 & Nape & Equig. & & $1-3$ & & + & + & + & + & & & & + & + & + & + & & & & \\
\hline 70109 & Nape & Equig. & & $1.8-3.5$ & + & + & + & + & + & & & & + & + & + & + & & & & \\
\hline 70114 & Nape & Equig. & Foliated & $2-3.5$ & + & + & + & + & + & + & & & + & + & + & & & & & \\
\hline 70303 & Xaisomboun & Equig. & & $1-3$ & & + & + & + & + & + & & & + & + & & & & & & + \\
\hline 70306 & Xaisomboun & Equig. & & $0.6-4.5$ & & + & + & + & + & + & & & + & + & & & & & & + \\
\hline 70402 & Xaisomboun & Porph. & & $0.005-0.04$ & + & + & + & + & + & & & & + & & & & & & & \\
\hline
\end{tabular}

Equig. $=$ Equigranular, Porph. $=$ Porphyritic

$\mathrm{Qtz}=$ Quartz, $\mathrm{Plg}=$ Plagioclase, $\mathrm{Kfs}=\mathrm{K}$-feldspar, $\mathrm{Bt}=$ Biotite, $\mathrm{Hbl}=$ Hornblende, $\mathrm{Ms}=$ Muscovite, Tur $=$ Tourmaline

Apt $=$ Apatite, Zir $=$ Zircon, $\mathrm{Mnz}=$ Monazite, Xen $=$ Xenotime, Aln $=$ Allanite, Tit $=$ Titanite, Alm $=$ Almandine, Thr $=$ Thorite 
biotite are partly illitized and chloritized, respectively by alteration in most samples. Biotite and hornblende commonly contain apatite and zircon within the crystals, exhibiting metamict by radioactivity. Recognized REE minerals and REE-bearing minerals are apatite, zircon, monazite, xenotime, allanite, titanite and almandine (Table 1; Fig. 3).

\subsubsection{Attapu district}

The granitic rock samples in Attapu are mediumgrained biotite granodiorite and hornblende-biotite granodiorite with K-feldspar phenocrysts. These granitic rocks are mostly metaluminous (alumina saturation index < 1.05; samples P725, P726 and P793) I-type series or peraluminous (sample P712) S-type granodiorite. Granodiorite of sample P793 is weakly foliated whereas the others are not deformed. K-feldspar phenocryst is common and is less than $20 \mathrm{~mm}$ in size. The occurrence of epidote is commonly recognized due to the saussuritization of plagioclase.

\subsubsection{Boneng district}

The granitic rocks in Boneng are fine- to medium grained equigranular in texture accompanied with porphyritic biotite granite and tourmaline-bearing biotite granodiorite. All of these granitic rocks are classified into peralminous S-type ilmenite-series. Plagioclase and biotite are commonly illitized and chloritized. Samples 62801, 62802 and 62809 are relatively weathered and contain pinkish to reddish K-feldspar. Sample 62818 is a tourmaline granite consisting of quartz and tourmaline. Sample 62815 is a greizen, which formed by hydrothermal activity associated with granitic magma, and consists of quartz and muscovite. DGM (2000) reported that REE contents of two granite samples from the Say Phou Ngou Pluton and Phou Thuon Pluton, located in the northwest of the Boneng, are 271 and $350 \mathrm{ppm}$, respectively.
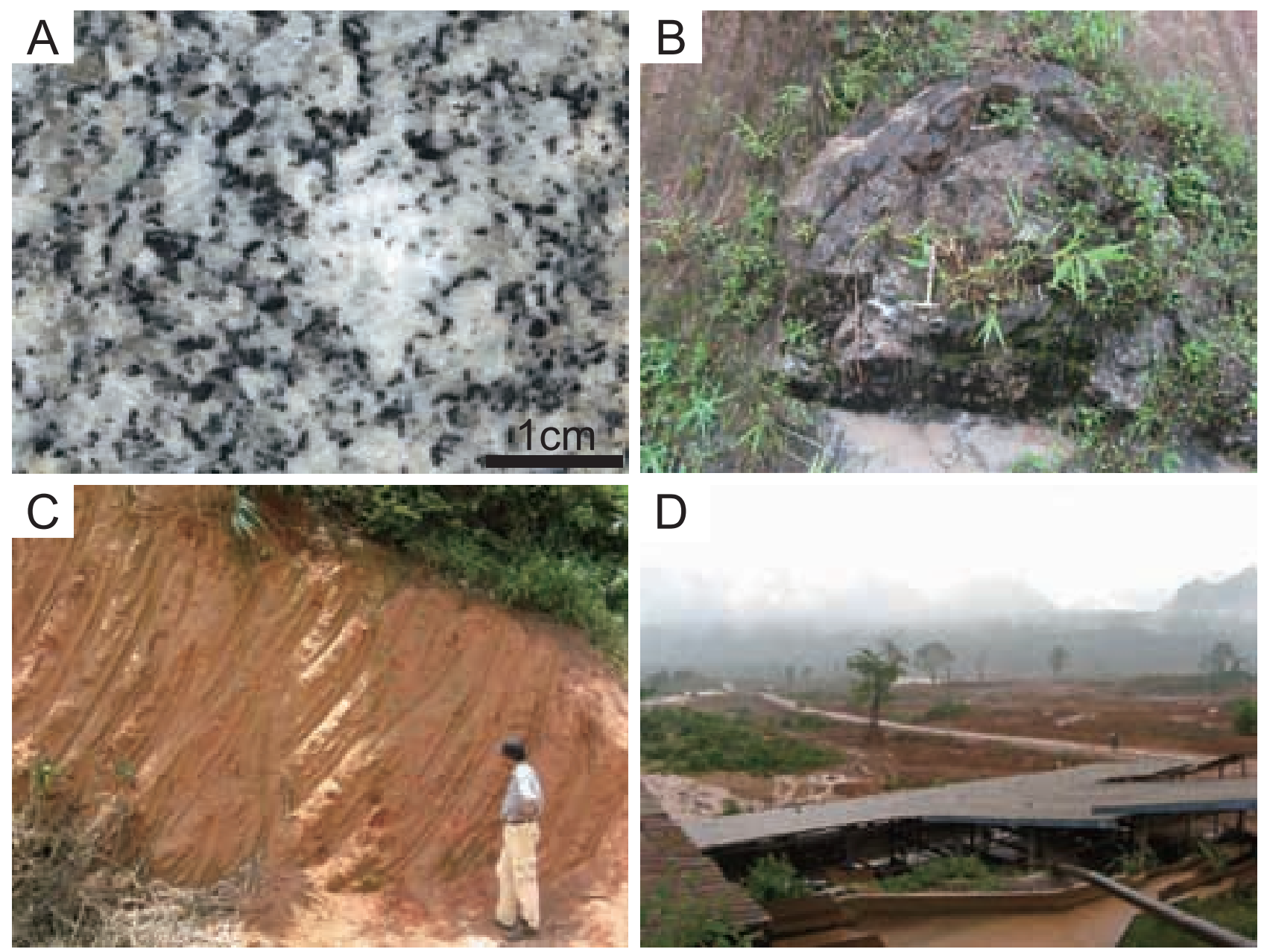

Fig. 2 Photographs of the studied granitic rocks and weathered crusts. (A) Representative medium-grained biotite granodiorite characterized by large feldspar phenocrysts (sample 62814). (B) Granodiorite showing onion structure by weathering within the weathered crust of the $C$ horizon (70101 and 70101C). (C) Weathered crust of a granitic rock which does not crop out on the surface (70307A, B1, B2 and C). (D) Sn bearing sediments derived from granitic rocks and a processing plant in the Boneng Sn mine (P797OR1, P797OR2, P797CN1 and P797CN2). 


\subsubsection{Nape district}

The granitic rocks in the Nape are S-type ilmeniteseries medium- to coarse-grained biotite granodiorite and granite, which are characterized by large K-feldspar phenocrysts with the range of $5-40 \mathrm{~mm}$ in size. Foliation within the granitic rocks is not common except for the sample 70114 which is weakly foliated. The occurrence of secondary muscovite by alteration can be recognized within biotite. Primary muscovite appears to be scarce but only the sample 63002 may be muscovitebiotite granite. Veinlets of illite and muscovite by alteration are also observed (sample 70101). DGM (2000) reported that REE contents of granite samples are 164 and $166 \mathrm{ppm}$ in this district.

\subsubsection{Xaisomboun district}

Granitic rocks consist of fine- to medium-grained biotite-hornblende granodiorite and granite porphyry in the Xaisomboun district. They are classified into either I-type ilmenite-series (samples 70304-70306) or
I-type magnetite-series (samples 70303 and 70402). No foliation is recognized in these samples. K-feldspar is generally microcline and less altered whereas plagioclase, biotite and hornblende are commonly altered. The occurrence of epidote by alteration is recognized within plagioclase and hornblende.

\subsection{Description of the weathered rock samples}

Totally 62 samples were collected from weathered crusts of the granitic rocks. The profile of the weathered crusts can be divided into $\mathrm{A}, \mathrm{B}$ and $\mathrm{C}$ horizons from upper part to lower part after the definition by $\mathrm{Wu}$ et al. (1990). The A horizon, dark brown to reddish dark brown soil, has the thickness ranging from 5 to $50 \mathrm{~cm}$. It is enriched in organic matter and clay minerals, and rock-forming minerals are not recognized except for quartz due to intense weathering. The B horizon is khaki, brown or reddish brown in color and shows no granitic texture in appearance (Fig. 2C). Plagioclase and biotite are scarcely present but $\mathrm{K}$-feldspar can be

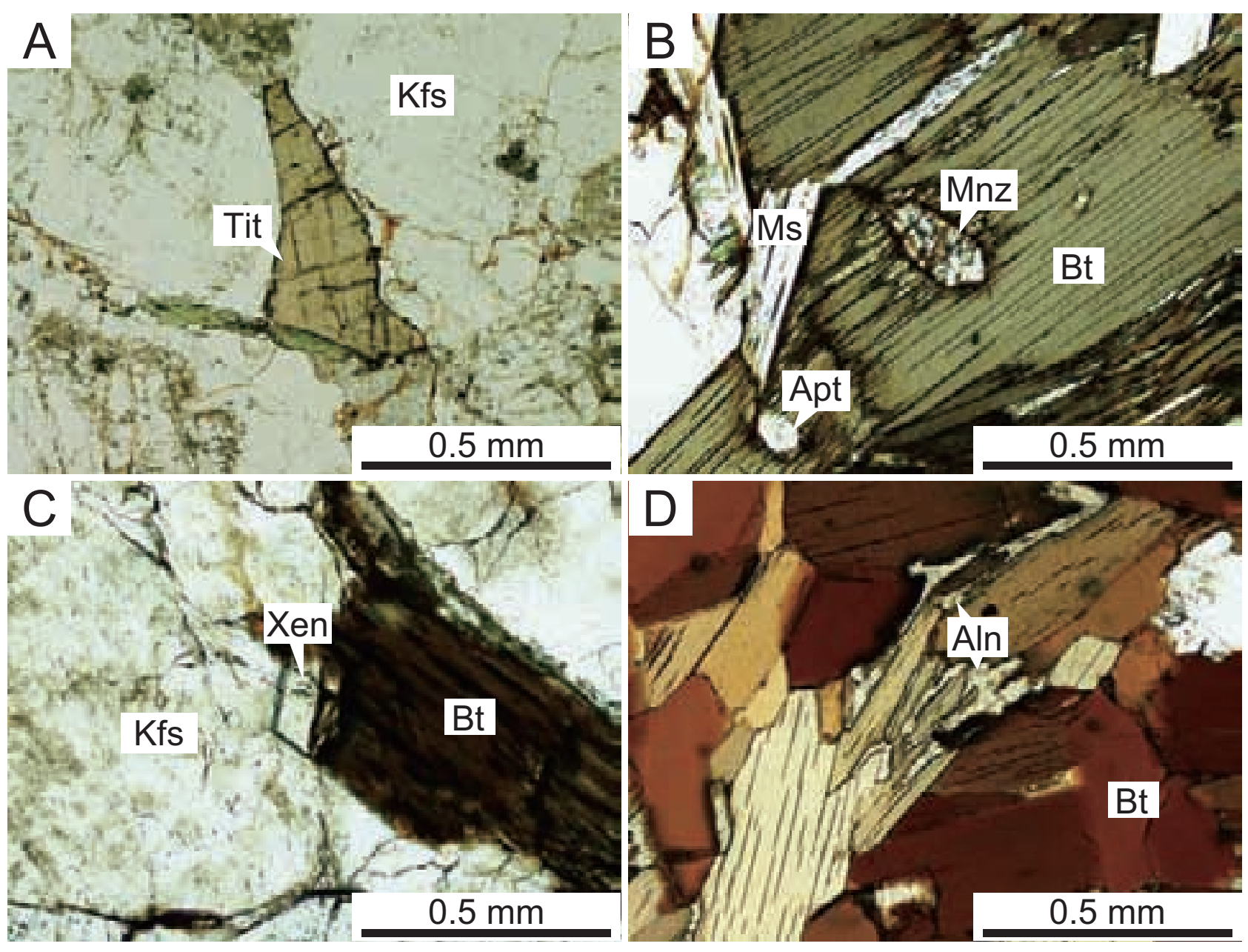

Fig. 3 Photomicrographs showing the occurrence of REE-bearing and REE minerals (open nicol). (A) Titanite in K-feldspar in the sample 62903. (B) Monazite and apatite in biotite (C) and xenotime with biotite in the sample 62901. (D) Anhedral-shaped allanite within biotite in the sample 70105. Abbreviations: Tit $=$ titanite, $\mathrm{Mnz}=$ monazite, $\mathrm{Apt}=$ apatite, Xen $=$ xenotime, $\mathrm{Aln}=$ allanite, $\mathrm{Kfs}=\mathrm{K}$-feldspar, $\mathrm{Ms}=$ muscovite, $\mathrm{Bt}=$ biotite . 
identified. This horizon is enriched in clay minerals with less organic matter. In some weathered crusts, the $\mathrm{B}$ horizon is divided into B1 and B2 horizons from top to bottom. The $\mathrm{C}$ horizon is a slightly fresh but fragile weathered crust exhibiting gray, khaki or brown color. Granitic texture and rock-forming minerals are readily recognized although they are apparently altered. The $\mathrm{C}$ horizon gradually changes to the $\mathrm{B}$ horizon and the boundary is generally unclear. Although it is hard to identify the fresh parent rocks of weathered crusts, most samples from weathered crusts are derived from biotite granite and granodiorite, and some others (70308B, 70308C, 70310B and 70310C) appears to be derived from hornblende-biotite granodiorite. The thickness of weathered crust consisting of the A, B and $\mathrm{C}$ horizons is variable because some weathered crusts were thinned or removed by erosion. It is roughly estimated to be $10 \mathrm{~m}$ on average and weathered crust in the Nape district is most developed among the surveyed districts. Weathered crust contains dominantly kaolin (kaolinite \pm halloysite), and subordinate illite (mainly -2M) and gibbsite as weathering products. In the Boneng district, gibbsite is more dominant than kaolin and illite. Hematite and goethite are common in reddish colored weathered crusts. Small amounts of smectite and chlorite are recognized in some samples, but no interstratified clay mineral is detected by X-ray diffractometry. The occurrence of vermiculite and zeolite is very rare. Samples 70307B2 and C contain REE phosphates such as monazite and rhabdophane which occur as dirty and anhedral shapes within feldspars (Fig. 4).

Eight kaolin-rich samples were collected in the Attapu and Nape districts. Samples P719CL1, P719CL2, P719CL3 and P788CL are considered to be derived from sedimentary rocks rich in clay minerals. Whitish color of samples P719CL1 and P719CL2 suggest that they underwent hydrothermal alteration and these samples consist of quartz, kaolin, illite and gibbsite. Other two samples (P719CL3 and P788CL) consist of quartz, feldspars, kaolin and illite. Samples 62804CL and 62806CL in the Boneng district are obtained from kaolin-rich veinlets hosted by granitic rocks of the sample 62805 and 62807 , respectively. They are composed of quartz, kaolin and gibbsite with a small amount of illite. Samples P798CL and P799CL are massive and hard lateriteic rocks consisting of quartz, illite, kaolin and goethite.

Ten samples were collected from sediments in the Boneng and Nape districts. The sediment samples were derived from sandstone, mica-schist and probably the mixture of sedimentary rocks and reworked granitic
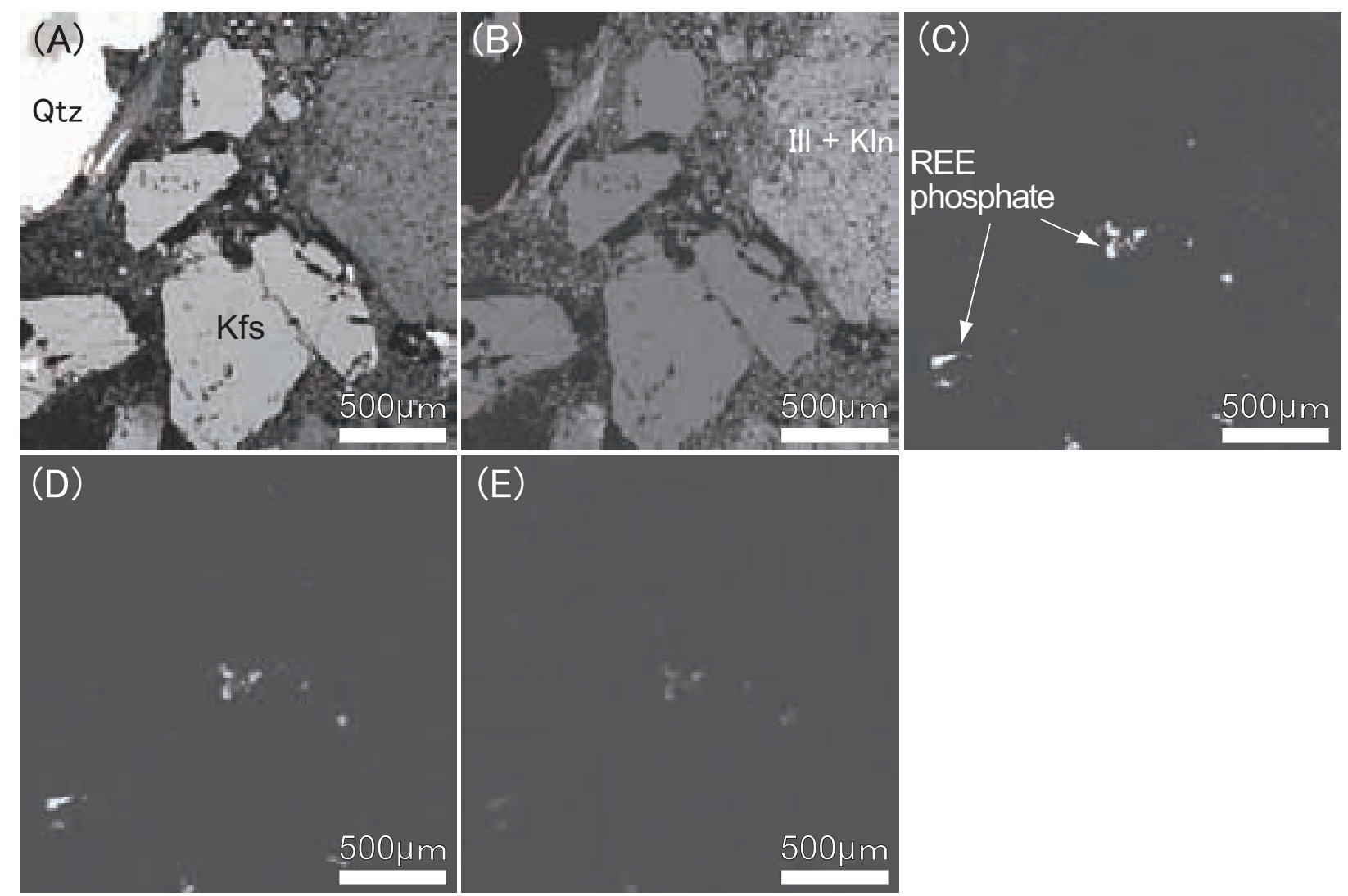

Fig. 4 Elemental mapping images of (A) Si, (B) Al, (C) P, (D) Ce and (E) Y in the sample 70307C determined by electron probe micro analyzer $($ EPMA). Abbreviations: $\mathrm{Qtz}=$ quartz, $\mathrm{Kfs}=\mathrm{K}$-feldspar, $\mathrm{Ill}=$ illite, $\mathrm{Kln}=$ kaolinite 
rocks. They consist of quartz, kaolin, illite and gibbsite but are less abundant in clay minerals compared with the kaolin-rich samples.

Sn-mineralized samples were collected in the Boneng Sn deposit (Fig. 4D). Samples P797OR1 and P797OR2 are Sn ore samples are taken from lateritic sediments which contain quartz, kaolin, illite and cassiterite. The other two samples (P797CN1 and P797CN2) are Sn concentrates after the mineral processing, consisting of quartz, goethite, zircon, cassiterite and xenotime.

\section{Analytical method}

All the rock samples were dried at room temperature and collected by quartering. The samples were crushed by a jaw crusher or iron mortar and were ground by a mill. Major and trace elements including REE were analyzed with X-ray fluorescence analyzer (XRF) and inductively coupled plasma mass spectrometry (ICPMS) of a Perkin Elmer SCIEX ELAN 6000 or 6100 at Activation Laboratories Ltd., Canada. Solution of rock samples for ICP-MS analyses was made by acid digestion of fused glass bead using lithium metaborate and tetraborate as flux. The presence of clay minerals was determined by X-ray diffractionmeter (XRD). An experiment of sequential leaching was conducted for the selected weathered rock samples with high REE contents. The sequential leaching was composed of 6 steps: 1) $1 \mathrm{M}$ sodium acetate for 1 hour, 2) 0.1 $\mathrm{M}$ sodium pyrophosphate for 1 hour, 3) $1.24 \mathrm{M}$ hydroxylamine at $30{ }^{\circ} \mathrm{C}$ for 2 hours, 4) hydroxylamine at $60{ }^{\circ} \mathrm{C}$ for 2 hours, 5) aqua regia digestion for 2 hours and 6) four acids digestion by hydrofluoric acid, nitric acid, perchloric acid and hydrochloric acid for 19 hours. Dominantly ion-exchanged or dissolved materials in the weathered rock samples at each step are 1) ionexchangeable clay minerals, 2) organic materials, 3) amorphous Fe oxides and crystalline Mn oxides, 4) Fe and Mn oxides, 5) clay minerals and phosphates and 6) silicates and some residual materials, respectively.

\section{Results}

The results of major and trace elements analyses are described in Appendix 1. Chondrite-normalized REE patterns (Sun and McDonough, 1989) of each district are illustrated by determining the average values of the granitic parent rocks, weathered crusts (A, B and C horizons), kaolin-rich rock and sediments (Fig. 5). Figure 6 shows the change in $\sum$ REE (total REE content), ¿LREE, $\sum$ HREE, P, Y, Zr, Th and U of any sample relative to the parent rock following the calculation formula by Nesbit (1979):

Change $(\%)=\left(\left(\mathrm{C}_{\mathrm{S}} / \mathrm{Al}_{2} \mathrm{O}_{3} \mathrm{~S}\right) /\left(\mathrm{C}_{\mathrm{PR}} / \mathrm{Al}_{2} \mathrm{O}_{3 \mathrm{PR}}\right)-1\right) \times 100$ Where $\mathrm{C}$ and $\mathrm{Al}_{2} \mathrm{O}_{3}$ are concentrations of any element and $\mathrm{Al}_{2} \mathrm{O}_{3}$, respectively. Subscripts of $\mathrm{S}$ and $\mathrm{PR}$ indicate of sample and of parent rock, respectively. We selected $\mathrm{Al}_{2} \mathrm{O}_{3}$ as an immobile element (oxide) in this paper because the immobility of $\mathrm{Al}_{2} \mathrm{O}_{3}$ within weathered crust of granitic rocks was assessed by Murakami and Ishihara (2006) and the result of this study (Appendix $1)$.

\subsection{Attapu district}

Parent granitic rocks in Attapu are enriched in LREE and depleted in HREE with a very weak negative $\mathrm{Eu}$ anomaly (Fig. 5A) compared with the granites in southern China and southwest of Japan (Ban and Zhao, 2008; Ishihara and Murakami, 2006). The REE patterns of the $\mathrm{B}$ and $\mathrm{C}$ horizons of the weathered crusts have the similar pattern with the granitic rocks whereas the patterns of the A horizon and kaolin-rich rock samples are different. The change in elements by weathering is easily recognized in Figure 6A. The A horizon is highly enriched in LREE and depleted in HREE. In contrast, the kaolin-rich rock is distinctly enriched in HREE although the REE content is not high. The $\mathrm{C}$ horizons are depleted in LREE and REE, whereas the $B$ horizons are enriched in both LREE and HREE. With regard to the other elements, Th and $U$ are significantly enriched whereas $\mathrm{P}$ is depleted in the A horizon. The average REE contents of the granitic rocks, B horizons, $\mathrm{C}$ horizons and kaolin-rich rocks are $166 \pm 98$ (standard deviation) ppm, $433 \pm 238$ ppm, $181 \pm 60$ ppm and 215 \pm 139 ppm, respectively.

\subsection{Boneng district}

All the samples in Boneng show the similar chondrite-normalized REE patterns each other and they are enriched in LREE with negative Eu anomalies. Figure 6B shows HREE are slightly depleted although some HREE (Tm, $\mathrm{Yb}$ and $\mathrm{Lu}$ ) of the A and B horizons appear to be enriched relative to the parent rocks. LREE of the A and B horizons are slightly enriched due to the enrichment of Ce. The kaolin-rich and sediment samples are generally depleted in REE relative to the parent granitic rocks. $\mathrm{P}$ is depleted in all the samples and $\mathrm{Zr}$ is enriched in the sediment samples. The average REE contents of the granitic rocks, B horizons, kaolinrich rocks, and sediments are $232 \pm 75$ ppm, $224 \pm 41$ ppm, $181 \pm 60$ ppm and $155 \pm 45$ ppm, respectively. Sn concentrate samples are rich in HREE and $\mathrm{Zr}$, whereas Sn ore samples are poor in REE (Appendix 1).

\subsection{Nape district}

All the samples in Nape have the similar REE patterns to each other with the enrichment of LREE and negative Eu anomalies (Fig. 5C), having a similarity with the REE pattern of the Boneng district. The A and $B$ horizons are weakly depleted in total REE and LREE relative to the parent rocks although they are slightly enriched in HREE (Fig. 6C). The C horizons are slightly 
enriched in REE relative to the parent rock whereas the enrichment of HREE is poor. The sediments are depleted in REE although HREE are enriched relative to LREE. The significant depletion of $\mathrm{P}$ in all the samples and the enrichment of $\mathrm{Zr}$ in the sediments are recognized. The average REE contents of the granitic rocks, $\mathrm{B}$ horizons and $\mathrm{C}$ horizons are $179 \pm 49 \mathrm{ppm}$, $165 \pm 56$ ppm and $205 \pm 103$ ppm, respectively.

\section{(A) Attapu}

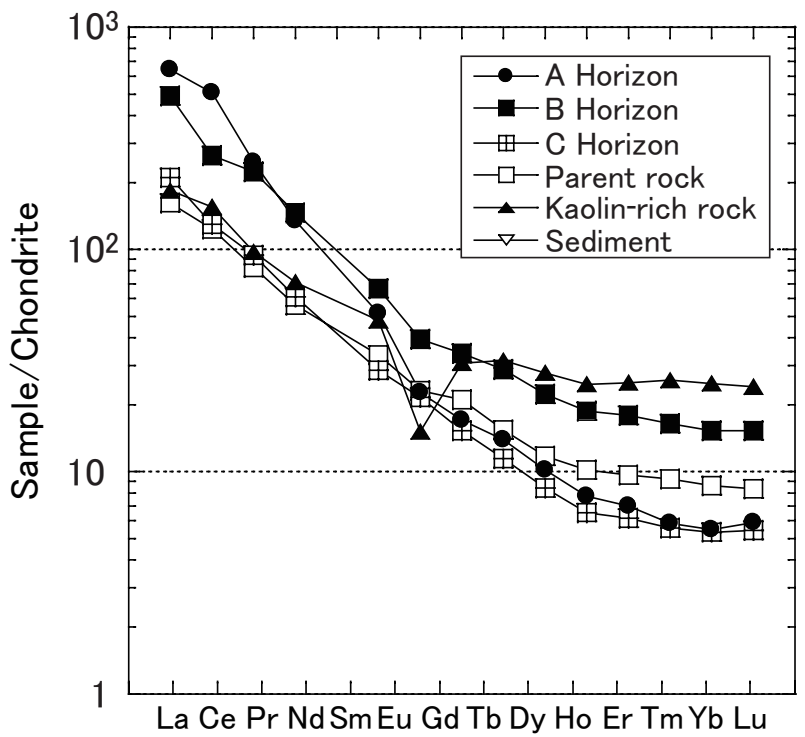

(C) Nape

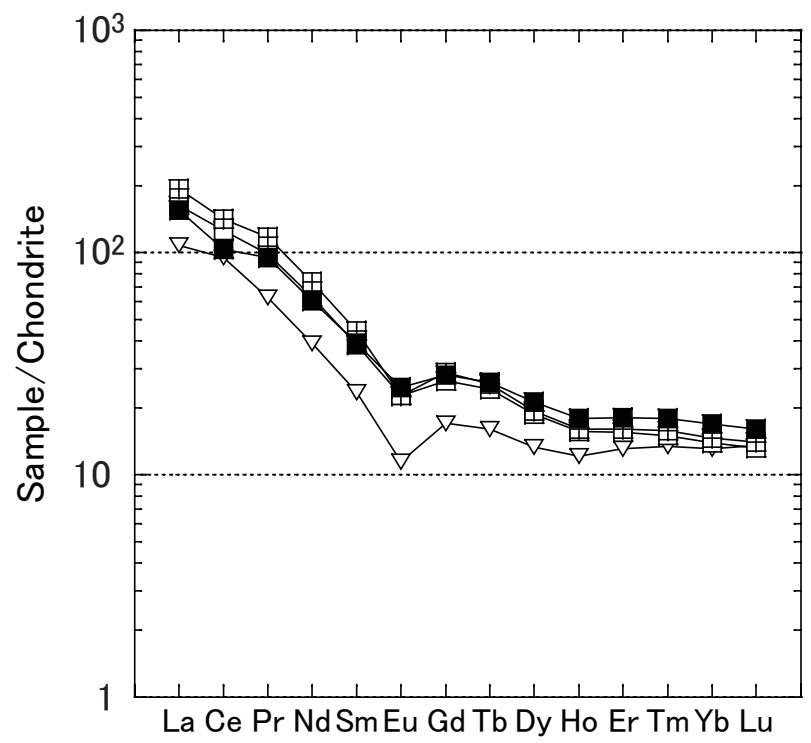

\subsection{Xaisomboun district}

In Xaisomboun, the granitic rocks have slightly low REE contents with the weak negative Eu anomaly (Fig. 5D) compared with the REE patterns of the Boneng and Nape districts. The REE pattern of the A and B horizons are similar to the parent rocks except for the Eu anomalies. Samples 70307A, B1, B2 and C, which are distinctly enriched in REE, are separately shown

(B) Boneng

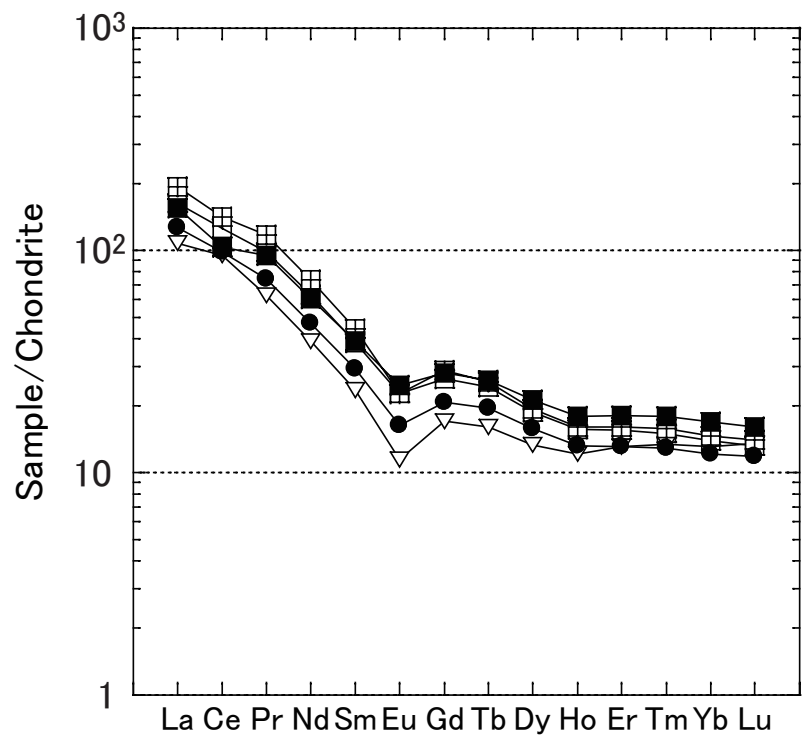

(D) Xaisomboun

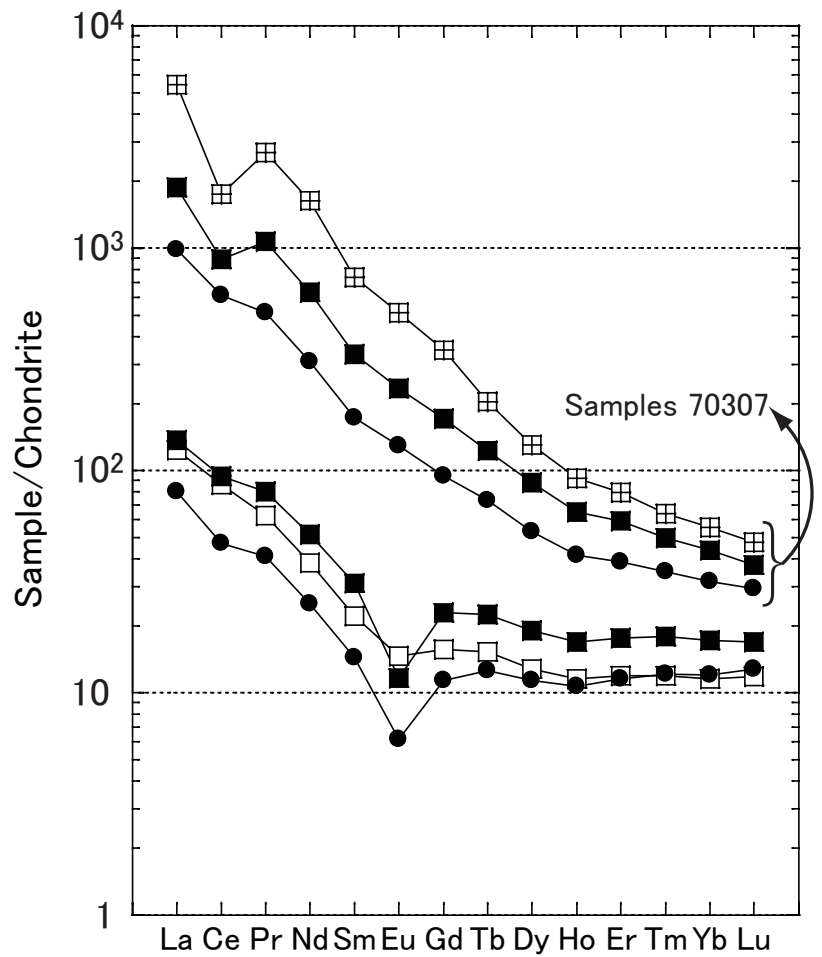

Fig. 5 Chondrite-normalized REE patterns of granitic rocks (parent rocks), their weathered crusts, clay-rich rocks and sediment samples in the (A) Attapu, (B) Boneng, (C) Nape and (D) Xaisomboun districts. 
in Figure 5D. They are especially enriched in LREE relative to HREE, showing the negative Ce anomalies and no Eu anomaly. The A horizons are depleted in REE relateive to the parent rocks whereas the $\mathrm{B}$ horizons are enriched in REE (Fig. 6D). Both of the A and B horizons are enriched in HREE relative to LREE. Zr,
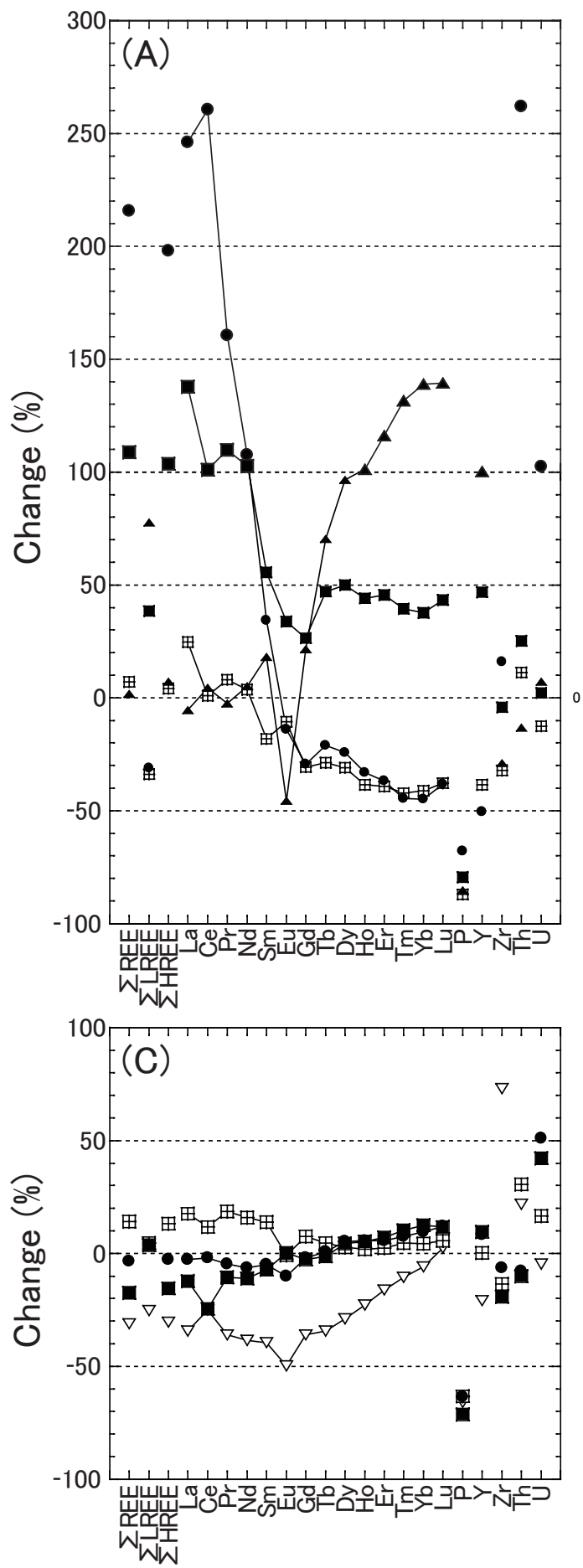

Th and $\mathrm{U}$ are enriched whereas $\mathrm{P}$ is depleted in both horizons. The change in elements is not illustrated for the samples 70307A - C because their parent rock was not identified. The average REE contents of the granitic rocks, A horizons and B horizons are $123 \pm 33$ ppm, 159 \pm 79 ppm and $205 \pm 103$ ppm, respectively.
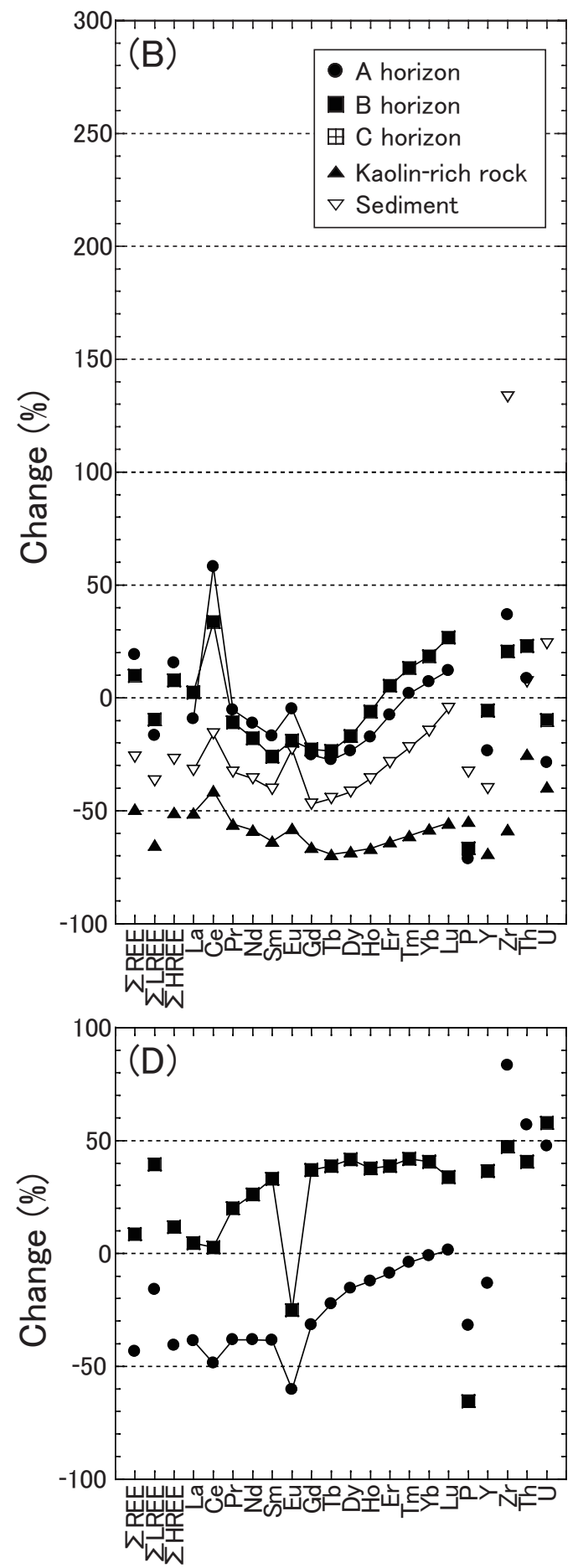

Fig. 6 Diagrams showing the change of elements relative to the parent rocks in the (A) Attapu, (B) Boneng, (C) Nape and (D) Xaisomboun districts. The percentage of the change is given by the following equation: $\left(\left(\mathrm{C}_{\mathrm{S}} / \mathrm{Al}_{2} \mathrm{O}_{3} \mathrm{~S}\right) /\left(\mathrm{CPR} / \mathrm{Al}_{2} \mathrm{O}_{3 \mathrm{PR}}\right)-1\right)$ $\times 100$. Contents of any element in a sample $\left(\mathrm{C}_{\mathrm{S}}\right)$ and parent rock $\left(\mathrm{C}_{\mathrm{PR}}\right)$ are normalized by contents of immobile $\mathrm{Al}_{2} \mathrm{O}_{3}$ in the sample $\left(\mathrm{Al}_{2} \mathrm{O}_{3 \mathrm{~S}}\right)$ and parent rock $\left(\mathrm{Al}_{2} \mathrm{O}_{3 \mathrm{PR}}\right)$, respectively. 


\subsection{All the rock samples}

All the granitic rocks show REE contents ranging from 35.5 to $338.5 \mathrm{ppm}$ with the average of $181 \pm 69$ $\mathrm{ppm}$. These values are consistent with the REE contents ranging from 164 to $350 \mathrm{ppm}$ reported by DGM (2000). The tourmaline granite (sample 62818) is excluded in calculating the average value because it is not a representative granitic rock at the studied area in the Boneng district. The tourmaline granite and greizen samples show the REE contents of 31.0 and $51.9 \mathrm{ppm}$ respectively, which are distinctly lower than those of the other granitic rocks. The REE contents of weathered crusts range from 37.9 to $817.4 \mathrm{ppm}$ with the average of $211 \pm 144 \mathrm{ppm}$ excluding the samples 70307A, B1, $\mathrm{B} 2$ and $\mathrm{C}$. The average REE contents of the horizons $\mathrm{A}, \mathrm{B}$ and $\mathrm{C}$ in all the samples are $210 \pm 190 \mathrm{ppm}, 217$ $\pm 156 \mathrm{ppm}$ and $196 \pm 97 \mathrm{ppm}$, respectively. Samples of $70307 \mathrm{~A}, \mathrm{~B} 1, \mathrm{~B} 2$ and $\mathrm{C}$ with the REE contents ranging from 885 to $3664 \mathrm{ppm}$ are distinctly enriched in REE. All the granitic rocks are depleted in HREE and relatively enriched in LREE (average LREE/HREE ratio $=9.40$ ) compared with the parent rocks of ionadsorption type deposits (Wu et al, 1990; Bao and Zhao, 2008). The weathered crusts of granitic rocks in Laos show the LREE/HREE ratios of 13.1 and they are generally depleted in HREE relative to LREE (Fig. 6A and $6 \mathrm{~B}$ ), whereas some weathered crusts are enriched in HREE relative to LREE (Fig. 6C and 6D). The LREE/HREE ratios of the A, B and C horizons are 16.9, 11.4 and 15.3 , respectively. The chondrite-normalized REE patterns exhibit downward-sloping REE patterns, indicating strong enrichment of LREE with weak enrichment of HREE relative to chondrite (Fig. 5). Kaolin-rich rock samples show the REE contents ranging from 111.4 to $418.7 \mathrm{ppm}$ with the average of $220 \pm 95 \mathrm{ppm}$. These samples have the LREE/HREE ratio $=11.5$ on average. Sediment samples show REE contents ranging from 93.9 to $224.0 \mathrm{ppm}$ with the average of $149 \pm 44 \mathrm{ppm}$. The REE contents of Sn ore and $\mathrm{Sn}$ concentrate samples are 186.3 and $50.8 \mathrm{ppm}$, and 133.4 and $514.8 \mathrm{ppm}$, respectively.

\subsection{Sequential leaching}

The result of the sequential leaching for Y, $\sum$ LREE, $\sum$ HREE and $\sum$ REE is summarized in Table 2 and the result of $\mathrm{Mn}, \mathrm{Zr}, \mathrm{Pb}, \mathrm{Th}, \mathrm{U}, \mathrm{Sc}, \mathrm{Y}$ and REE is shown in Appendix 2. The results indicate that $Y$ and REE occur within ion-exchangeable minerals (mostly clay minerals) at the step 1, clay minerals and phosphates at the step 5 and/or residual minerals such as zircon. By contrast, small amounts of $Y$ and REE are present within organic materials, Fe oxides, Mn oxides and silicates. The proportion of the exchangeable $\sum$ REE (step 1) to $\sum$ REE of total fusion analysis ranges widely from 14.2 to $72.7 \%$. The proportion of $\sum$ HREE is higher than that of $\sum$ LREE at the step 1 for all the samples. The proportions of the exchangeable $\mathrm{Y}$ and $\sum$ HREE have a positive correlation to each other (Table 2). The majority of $\mathrm{Zr}$ was not dissolved by the sequential leaching from the step 1 to 5 and it is present as residual minerals (Appendix 2). As Th is generally dissolved at the step 5, the host minerals are clay and phosphate minerals (Appendix 2).

\section{Discussions}

\subsection{Enrichment of REE in granitic rocks}

Relatively low $\mathrm{SiO}_{2}$ contents and $\mathrm{Rb} / \mathrm{Sr}$ ratios of granitic rocks in the surveyed areas suggest that they are mostly classified into granodiorite with some granite and diorite. These granitic rocks are not highly differentiated compared with representative granites of the southwest Japan reported by Ishihara and Murakami (2006) (Fig. 7A). The poor differentiation of magma for granite is also indicated by the small negative anomalies of $\mathrm{Eu}$ in the chondrite-normalized REE patterns (Fig. $5)$. The granitic rocks are more fractionated in the following order: the Xaisomboun, Attapu, Nape and Boneng districts (Fig. 7A). This order is concordant with the result that the average REE contents of the granitic rocks increase in the following order of the Xaisomboun (123 ppm), Attapu (166 ppm), Nape (179 ppm) and Boneng (232 ppm) districts because REE generally concentrate in melt as incompatible elements in the process of crystalization differentiation. A positive correlation between $\mathrm{SiO}_{2}$ contents and $\sum$ HREE suggests that HREE are enriched by the fractionation of magma (Fig. 7B). Ishihara and Murakami (2006) demonstrated that granitic rocks with high $\mathrm{SiO}_{2}$ contents $(>\sim 72 \%)$ become enriched in HREE in the southwest Japan (Fig. 5B). The HREE-enriched granites of REE deposits in southern China also have higher $\mathrm{SiO}_{2}$ contents ranging from 70 to $76 \%$ (Fig. 7B; Wu et al., 1990). The granitic rocks in southern Laos are slightly depleted in $\mathrm{SiO}_{2}$ and HREE, compared with those in the southwest Japan and southern China.

No significant correlation is identified between $\sum$ LREE and $\mathrm{SiO}_{2}$ contents of granitic rocks, but LREE contents are relatively higher in the range of $65-75$ $\% \mathrm{SiO}_{2}$ (Fig. 7C). As LREE generally occupies the majority of REE in content, the diagrams of $\sum$ LREE (Fig. 7C) and $\sum$ REE (Fig. 7D) versus $\mathrm{SiO}_{2}$ contents show a similar pattern to each other. $\mathrm{The} \mathrm{SiO}_{2}$-rich sample (62818) composed mainly of quartz and tourmaline, shows $31.0 \mathrm{ppm}$ REE, which is apparently lower than the others. This result suggests that REE minerals crystallized before tourmaline crystallization in highly fractionated magma. The greizen sample (62815) with $51.9 \mathrm{ppm}$ REE, which is lower than the REE contents of the granitic rocks in this area, suggests that greizen-related hydrothermal fluid is depleted in REE relative to the parent rock. The REE content of 
granitic rocks in Laos ranging from 35 to $339 \mathrm{ppm}$ is roughly equal to that of granites in ion-adsorption type deposits (130 - 350 ppm; Wu et al, 1990; Bao and Zhao, 2008). The REE content in ion-adsorption type deposits is apparently lower than ore grades of $1-8 \%$ REE from carbonatite-related REE deposits and prospects in China and North America (Wu et al., 1996; Castor, 2008; Wu, 2008). Although some of the granitic rocks in the ion-adsorption type deposits are distinctly enriched in HREE (LREE/HREE $=0.92$ 2.45) compared with the other REE ores, the others are enriched in LREE (LREE/HREE $=6.7$ - 18.7) as
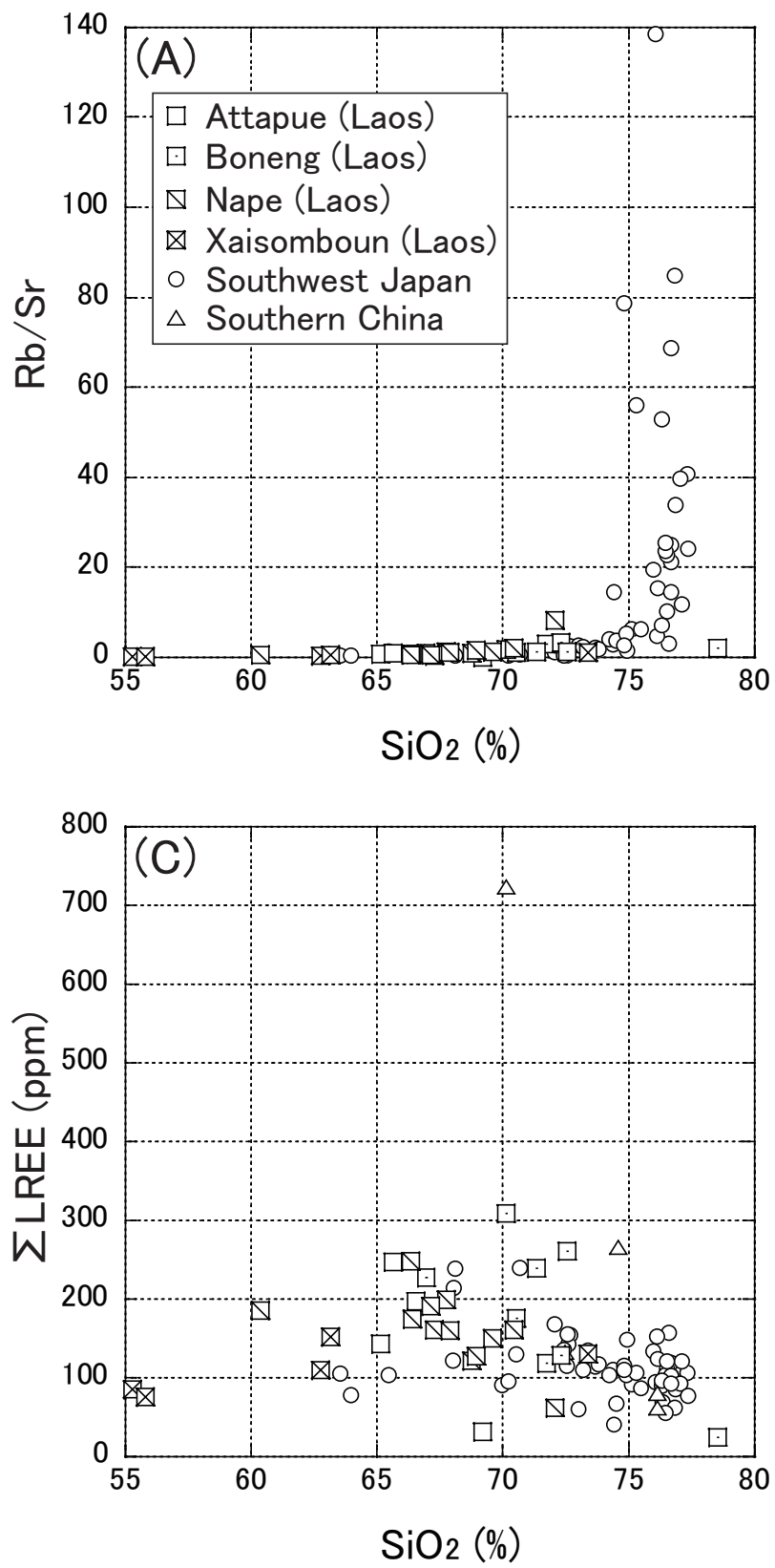

reported by Wu et al. (1990) and Bao and Zhao (2008). All of the studied granitic rocks in Laos are depleted in HREE and enriched in LREE, showing intermediate to high LREE/HREE ratios with the range of 6.2 - 15.6 (Appendix 1). From these results, it is concluded that the surveyed granitic rocks in central and southern Laos are not highly fractionated for granite, resulting in the depletion of HREE. Moderate REE contents with the depletion of HREE suggest that the granitic rocks, which are the parent rocks of weathered crusts, have a low potential for HREE resources whereas they may have a potential for LREE mineralization.
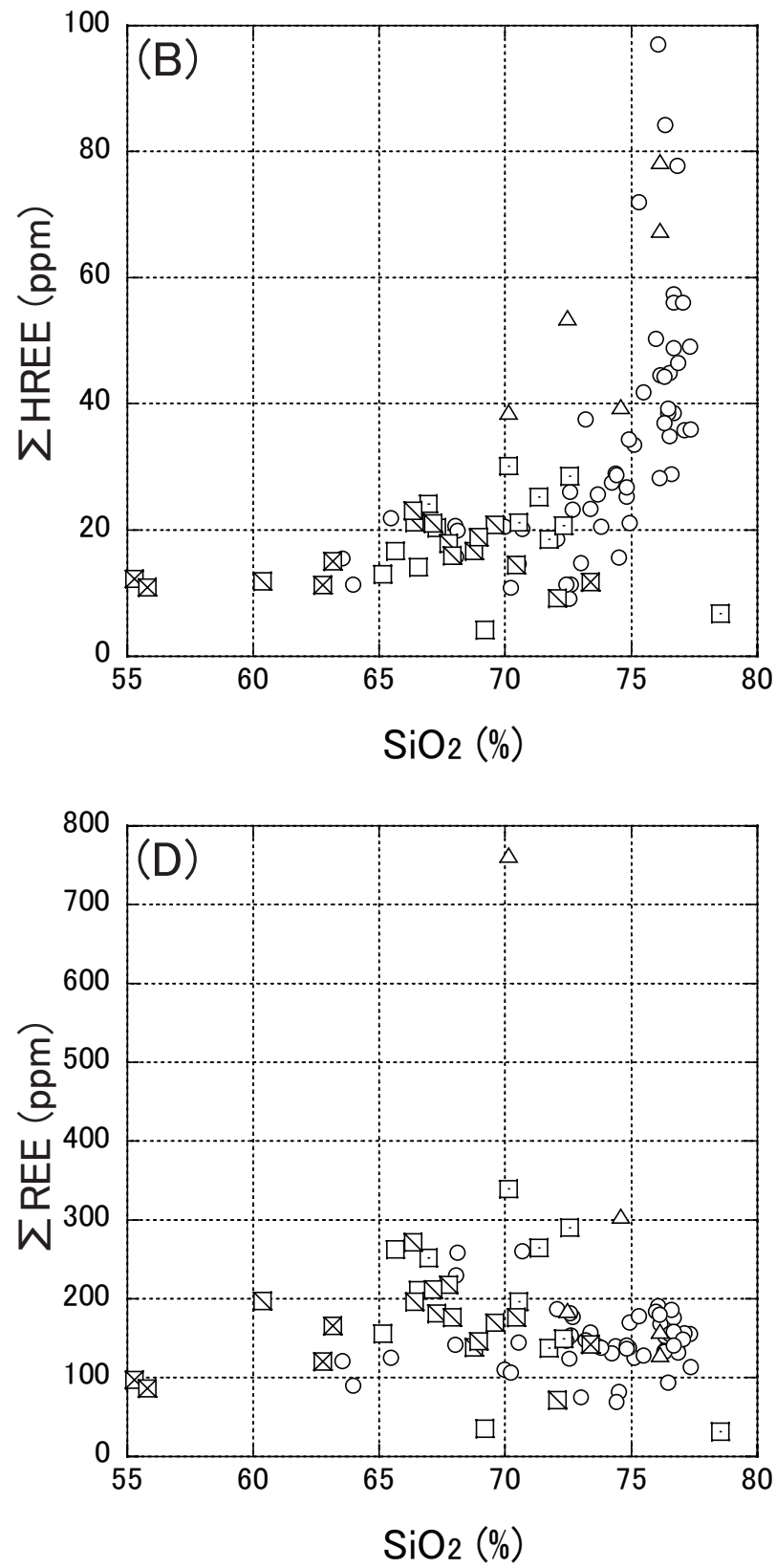

Fig. 7 Diagrams showing (A) Rb/Sr ratio, (B) $\sum$ LREE, (C) $\sum$ HREE and (D) $\sum$ REE versus $\mathrm{SiO}_{2}$ contents of granitic rocks in the central and southern Laos, Southwest Japan (Ishihara and Murakami, 2006) and southern China (Wu et al., 1990; Bao and Zhao, 2008). 


\subsection{Enrichment of REE by weathering}

Chemical index of alteration (CIA) proposed by Nesbitt and Young (1982) is applied to estimate the degree of weathering of granitic rocks in this study. The CIA value is given by simple calculation of molecular proportions:

$\mathrm{CIA}=\left[\mathrm{Al}_{2} \mathrm{O}_{3} /\left(\mathrm{Al}_{2} \mathrm{O} 3+\mathrm{CaO} *+\mathrm{Na}_{2} \mathrm{O}+\mathrm{K}_{2} \mathrm{O}\right)\right] \times 100(\%)$ Where $\mathrm{CaO}^{*}$ is the $\mathrm{CaO}$ content in silicates. Unaltered feldspars (anorthite, albite and orthoclase) give a CIA value of $50 \%$. Biotite and muscovite, which are peraluminous rock-forming minerals, generally give CIA values of $65-75$ and $\sim 75 \%$, respectively. Illite and kaolinite, which are common clay minerals in weathered crusts, indicate CIA values of $75-85$ and $100 \%$, respectively. Thus, CIA values of granitic rocks and weathered crusts in this study range from $\sim 50$ to $100 \%$, suggesting the degree of argillation, from feldspars through illite to kaolinite. Figure 8A indicates that CIA values increase by chemical weathering in the following order: granitic rocks and $\mathrm{A}, \mathrm{B}$ and $\mathrm{C}$ horizons of weathered crusts. The CIA values of the C, B and A horizons represent $55-76 \%, 69-96 \%$ and $73-$ $97 \%$, respectively. The CIA value of the C horizon is intermediate between the least altered granitic rocks and the $\mathrm{B}$ horizon, whereas a difference in CIA values between the $\mathrm{B}$ and $\mathrm{A}$ horizons is relatively unclear because the difference to distinguish these two horizons results mainly from the amount of organic matter. Weathered crusts of ion-adsorption type deposits show CIA values ranging from 66 to $92 \%$ (Wu et al., 1990; Murakami and Ishihara, 2008; Fig. 8A), and this suggests that most of weathered crusts of granitic rocks and kaolin-rich rocks in central and southern Laos are highly weathered and enriched in clay minerals as much as the ion-adsorption type deposits. The presence of clay minerals is also suggested by the diagram of $\Sigma$ REE versus LOI (loss on ignition) in Figure 8B. The weathered samples in Laos contain kaolinite, halloysite, gibbsite, illite and goethite as weathering products and these hydrous minerals elevate the LOI contents. Most of the weathered rock samples in Laos show LOI contents which are identical to or higher than those of the weathered crusts in southern China (Fig. 8B). The B horizon and kaolin-rich samples in Laos especially have higher LOI contents with the range of $5-15$ $\%$ in most of the samples, suggesting that they are sufficiently weathered and enriched in clay and hydrous minerals, which may have the ion-adsorption type REE mineralization.

\subsubsection{Attapu district}

In the each studied district of Laos, the most REEenriched horizon is variable and is dependant on the each weathered profile. Although the most REEenriched sample in the Attapu district is the A horizon $\left(\sum \mathrm{REE}=568 \mathrm{ppm}\right)$, it was evaluated by the only one sample (P725A). Moreover, the higher REE content results from the high $\mathrm{Ce}$ content (311 ppm). This Ce enrichment with the positive $\mathrm{Ce}$ anomaly $\left(\mathrm{Ce} / \mathrm{Ce}^{*}=\right.$ 1.28 ) in the A horizon is probably derived from the formation of tetravalent $\mathrm{Ce}$ under oxidizing condition near the surface (Henderson, 1984). The elevated REE content may be due to the presence of REEbearing titanite, which is observed in granodiorite of the sample P725. The occurrence of exchangeable REE is minor and the majority of REE is present in silicates and poorly-soluble minerals (Table 2). The $B$ horizons are generally enriched in REE with the enrichment of LREE relative to HREE (LREE/HREE = 23.2), and kaolin-rich rocks are enriched in HREE $($ LREE/HREE $=7.8)$ without significant changes in LREE (Fig. 6A). The B horizons show a moderate REE content on average (433 ppm), whereas the kaolin-rich samples contain less REE (215 ppm). Zr, Th and U of the two samples are not remarkably enriched relative to the parent rocks whereas $\mathrm{P}$ is distinctly depleted. These results suggest that host minerals of REE such as monazite, xenotime and allanite are rarely concentrated after weathering, although only the sample P791B2 contains relatively high $\mathrm{Th}$ and $\mathrm{Zr}$ in the bulk-rock analysis (Fig. 8D and E). For the sample P716B, $73 \%$ of $\sum$ REE is ion-exchangeable (Table 2), indicating the occurrence of ion-adsorption type REE mineralization. The other samples from the B horizon (P791B1 and P791B2) have some amount of exchangeable REE although REE are mainly present in phosphates and poorly-soluble minerals (Table 2 ). The kaolin-rich sample (P788CL) contains REE in ion-exchangeable clay minerals, phosphate, silicate and poorly-soluble minerals (Table 2). Thus, these results suggest that some of the B horizons in the Attapu district may have a potential of ion-adsorption type REE mineralization with the enrichment of both LREE and HREE.

\subsubsection{Boneng district}

Some samples (62808A, 62810B and P799CL) show positive Ce anomaly whereas other samples (62803B, 62805B and 62807B) show negative Ce anomaly in Boneng. These positive and negative anomalies suggest the removal of REE except for Ce in oxidizing condition near the surface and deposition of the removed REE in less oxidizing condition, respectively. The enrichment of REE is variable due to the removal and the deposition of REE with minor $\mathrm{Ce}$, but the $\mathrm{A}$ and $\mathrm{B}$ horizons are slightly enriched in REE (Fig. 6B). The enrichment of HREE relative to LREE is recognized in the A horizons, B horizons and sediment samples; that is due to the presence of residual zircon suggested by the enrichment of $\mathrm{Zr}$ (Fig. 6B). The result of sequential leaching also suggests that the majority of REE is present in residual zircon and phosphate minerals with a small amount of exchangeable REE (Table 2). Sn concentrate sample 

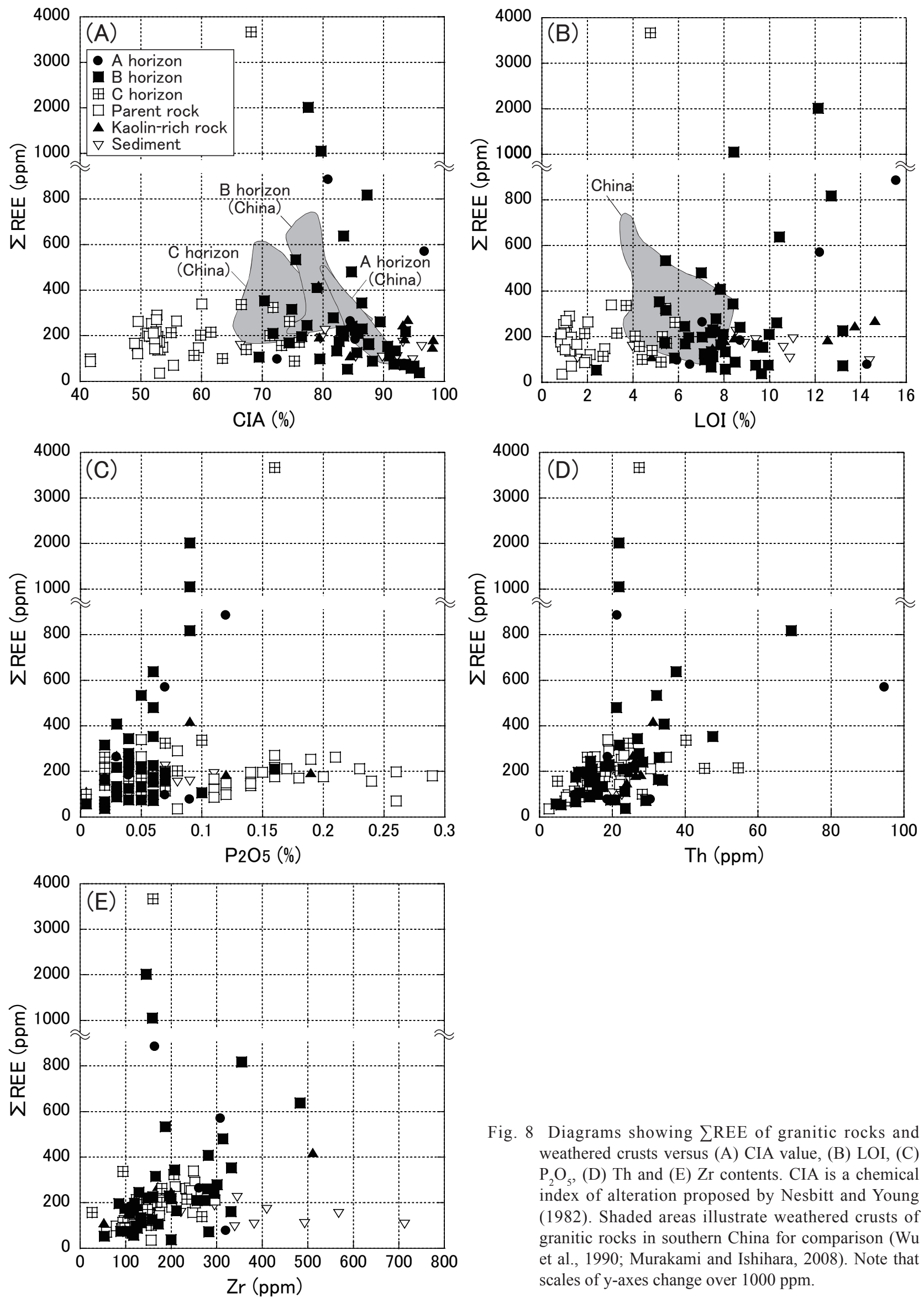

Fig. 8 Diagrams showing $\sum$ REE of granitic rocks and weathered crusts versus (A) CIA value, (B) LOI, (C) $\mathrm{P}_{2} \mathrm{O}_{5}$, (D) Th and (E) $\mathrm{Zr}$ contents. CIA is a chemical index of alteration proposed by Nesbitt and Young (1982). Shaded areas illustrate weathered crusts of granitic rocks in southern China for comparison (Wu et al., 1990; Murakami and Ishihara, 2008). Note that scales of y-axes change over $1000 \mathrm{ppm}$. 
Table. 2 Summary of the result of sequential leaching for representative REE-rich weathered rock sample

\begin{tabular}{|c|c|c|c|c|c|c|c|c|c|c|c|c|}
\hline \multirow[b]{2}{*}{ Sample \# } & \multirow[b]{2}{*}{ Rock type } & \multirow[b]{2}{*}{$\begin{array}{c}\text { Dominant } \\
\text { minerals }\end{array}$} & \multirow[b]{2}{*}{$\begin{array}{l}\text { Leaching } \\
\text { step }^{* 1}\end{array}$} & \multirow[b]{2}{*}{$\begin{array}{l}\text { Ion-exchanged or } \\
\text { dissolved materials }\end{array}$} & \multicolumn{2}{|c|}{$\mathrm{Y}$} & \multicolumn{2}{|c|}{$\Sigma$ LREE } & $\Sigma \mathrm{H}$ & & $\sum \mathrm{R}$ & \\
\hline & & & & & $\begin{array}{l}\text { Conc. } \\
\text { (ppm) }\end{array}$ & $\begin{array}{c}\text { Prop. }{ }^{2} \\
(\%)\end{array}$ & $\begin{array}{l}\text { Conc. } \\
\text { (ppm) }\end{array}$ & $\begin{array}{c}\text { Prop. } \\
(\%)\end{array}$ & $\begin{array}{l}\text { Conc. } \\
\text { (ppm) }\end{array}$ & $\begin{array}{c}\text { Prop. } \\
(\%)\end{array}$ & $\begin{array}{l}\text { Conc. } \\
\text { (ppm) }\end{array}$ & $\begin{array}{c}\text { Prop. } \\
(\%)\end{array}$ \\
\hline & & & Step 1 & Ion exchangeable minerals & 45.8 & 64.5 & 428.9 & 72.7 & 34.3 & 72.8 & 463.2 & 72.7 \\
\hline & & Qtz & Step 2 & Organic materials & 1.18 & 1.7 & 9.68 & 1.6 & 0.761 & 1.6 & 10.44 & 1.6 \\
\hline & & $\mathrm{Kfs}$ & Step 3 & Amorphous $\mathrm{Fe}$ oxides \& Mn oxides & 0.40 & 0.6 & 3.68 & 0.6 & 0.300 & 0.6 & 3.98 & 0.6 \\
\hline P716B & Weathered & $\mathrm{K} \ln$ & Step 4 & Fe \& Mn oxides & 0.053 & 0.1 & 1.56 & 0.3 & 0.057 & 0.1 & 1.62 & 0.3 \\
\hline & & Ill & Step 5 & Clay minerals \& phosphates & 1.0 & 1.4 & 30.5 & 5.2 & 1.3 & 2.8 & 31.8 & 5.0 \\
\hline & & & Step 6 & Silicates \& residue & 1.9 & 2.7 & 22.5 & 3.8 & 2.0 & 4.2 & 24.5 & 3.8 \\
\hline & & & - & Residue $^{* 3}$ & 20.7 & 29.1 & 93.6 & 15.9 & 8.4 & 17.8 & 102.0 & 16.0 \\
\hline & & & Step 1 & Ion exchangeable minerals & 3.48 & 36.6 & 77.2 & 13.8 & 3.28 & 34.8 & 80.5 & 14.2 \\
\hline & & Qtz & Step 2 & Organic materials & 0.08 & 0.8 & 2.01 & 0.4 & 0.079 & 0.8 & 2.08 & 0.4 \\
\hline & & $\mathrm{Kfs}$ & Step 3 & Amorphous Fe oxides \& Mn oxides & 0.132 & 1.4 & 15.65 & 2.8 & 0.150 & 1.6 & 15.80 & 2.8 \\
\hline P725A & Weathered & Gib & Step 4 & $\mathrm{Fe} \& \mathrm{Mn}$ oxides & 0.012 & 0.1 & 14.59 & 2.6 & 0.064 & 0.7 & 14.66 & 2.6 \\
\hline & & $\mathrm{K} \ln$ & Step 5 & Clay minerals \& phosphates & 1.16 & 12.2 & 72.2 & 12.9 & 1.8 & 19.1 & 74.0 & 13.0 \\
\hline & & Ill & Step 6 & Silicates \& residue & 1.9 & 20.0 & 116.8 & 20.9 & 3.3 & 35.0 & 120.1 & 21.1 \\
\hline & & & - & Residue & 2.7 & 28.8 & 259.8 & 46.5 & 0.8 & 8.0 & 260.6 & 45.9 \\
\hline & & & Step 1 & Ion exchangeable minerals & 15.9 & 62.6 & 142.7 & 27.7 & 11.81 & 71.3 & 154.5 & 29.0 \\
\hline & & Qtz & Step 2 & Organic materials & 0.46 & 1.8 & 3.53 & 0.7 & 0.286 & 1.7 & 3.82 & 0.7 \\
\hline & & $\mathrm{Kfs}$ & Step 3 & Amorphous $\mathrm{Fe}$ oxides \& Mn oxides & 0.283 & 1.1 & 5.21 & 1.0 & 0.228 & 1.4 & 5.44 & 1.0 \\
\hline P791B1 & Weathered & Ill & Step 4 & Fe \& Mn oxides & 0.038 & 0.2 & 5.43 & 1.1 & 0.052 & 0.3 & 5.48 & 1.0 \\
\hline & & $\mathrm{K} \ln$ & Step 5 & Clay minerals \& phosphates & 1.67 & 6.6 & 228.2 & 44.2 & 2.9 & 17.5 & 231.1 & 43.4 \\
\hline & & & Step 6 & Silicates \& residue & 1.0 & 3.9 & 23.5 & 4.5 & 1.2 & 7.2 & 24.7 & 4.6 \\
\hline & & & - & Residue & 6.0 & 23.8 & 107.3 & 20.8 & 0.09 & 0.5 & 107.4 & 20.2 \\
\hline & & & Step 1 & Ion exchangeable minerals & 35.4 & 60.7 & 310.6 & 39.8 & 25.62 & 67.9 & 336.2 & 41.1 \\
\hline & & Qtz & Step 2 & Organic materials & 0.77 & 1.3 & 6.28 & 0.8 & 0.488 & 1.3 & 6.77 & 0.8 \\
\hline & & $\mathrm{K} \ln$ & Step 3 & Amorphous Fe oxides \& Mn oxides & 0.189 & 0.3 & 5.89 & 0.8 & 0.154 & 0.4 & 6.04 & 0.7 \\
\hline P791B2 & Weathered & Ill & Step 4 & $\mathrm{Fe} \& \mathrm{Mn}$ oxides & 0.040 & 0.1 & 18.50 & 2.4 & 0.112 & 0.3 & 18.6 & 2.3 \\
\hline & & $\mathrm{Kfs}$ & Step 5 & Clay minerals \& phosphates & 3.73 & 6.4 & 242.7 & 31.1 & 5.8 & 15.4 & 248.5 & 30.4 \\
\hline & & & Step 6 & Silicates \& residue & 2.9 & 5.0 & 20.7 & 2.7 & 3.4 & 9.0 & 24.1 & 3.0 \\
\hline & & & - & Residue & 15.3 & 26.2 & 175.1 & 22.5 & 2.14 & 5.7 & 177.2 & 21.7 \\
\hline & & & Step 1 & Ion exchangeable minerals & 15.0 & 48.5 & 162.1 & 40.9 & 12.53 & 55.7 & 174.6 & 41.7 \\
\hline & & Qtz & Step 2 & Organic materials & 0.60 & 1.9 & 5.77 & 1.5 & 0.419 & 1.9 & 6.18 & 1.5 \\
\hline & & $\mathrm{Kfs}$ & Step 3 & Amorphous $\mathrm{Fe}$ oxides \& Mn oxides & 0.224 & 0.7 & 2.61 & 0.7 & 0.182 & 0.8 & 2.79 & 0.7 \\
\hline P788CL & Kaolin-rich rock & Kln & Step 4 & Fe \& Mn oxides & 0.020 & 0.1 & 1.55 & 0.4 & 0.033 & 0.1 & 1.58 & 0.4 \\
\hline & & Ill & Step 5 & Clay minerals \& phosphates & 1.78 & 5.8 & 99.8 & 25.2 & 2.9 & 12.9 & 102.7 & 24.5 \\
\hline & & & Step 6 & Silicates \& residue & 2.4 & 7.8 & 62.1 & 15.7 & 2.8 & 12.4 & 64.9 & 15.5 \\
\hline & & & - & Residue & 10.9 & 35.2 & 62.3 & 15.7 & 3.6 & 16.2 & 65.9 & 15.7 \\
\hline & & & Step 1 & Ion exchangeable minerals & 14.8 & 25.0 & 108.5 & 24.3 & 9.82 & 28.6 & 118.3 & 24.6 \\
\hline & & Qtz & Step 2 & Organic materials & 0.48 & 0.8 & 3.42 & 0.8 & 0.296 & 0.9 & 3.72 & 0.8 \\
\hline & & $\mathrm{Kfs}$ & Step 3 & Amorphous Fe oxides \& Mn oxides & 0.842 & 1.4 & 6.82 & 1.5 & 0.537 & 1.6 & 7.36 & 1.5 \\
\hline $62810 \mathrm{~B}$ & Weathered & Gib & Step 4 & $\mathrm{Fe} \& \mathrm{Mn}$ oxides & 0.922 & 1.6 & 29.69 & 6.7 & 0.567 & 1.7 & 30.3 & 6.3 \\
\hline & & $\mathrm{K} \ln$ & Step 5 & Clay minerals \& phosphates & 15.3 & 25.8 & 79.2 & 17.8 & 10.8 & 31.5 & 90.0 & 18.7 \\
\hline & & Ill & Step 6 & Silicates \& residue & 6.3 & 10.6 & 16.6 & 3.7 & 7.7 & 22.5 & 24.3 & 5.1 \\
\hline & & & - & Residue & 20.6 & 34.7 & 201.5 & 45.2 & 4.55 & 13.3 & 206.1 & 42.9 \\
\hline & & & Step 1 & Ion exchangeable minerals & 42.0 & 53.9 & 388.8 & 46.6 & 32.10 & 62.8 & 420.9 & 47.6 \\
\hline & & Qtz & Step 2 & Organic materials & 2.02 & 2.6 & 22.09 & 2.6 & 1.477 & 2.9 & 23.6 & 2.7 \\
\hline & & $\mathrm{Kfs}$ & Step 3 & Amorphous Fe oxides \& Mn oxides & 2.19 & 2.8 & 44.56 & 5.3 & 1.706 & 3.4 & 46.3 & 5.2 \\
\hline $70307 \mathrm{~A}$ & Weathered & $\mathrm{K} \ln$ & Step 4 & $\mathrm{Fe} \& \mathrm{Mn}$ oxides & 0.376 & 0.5 & 18.53 & 2.2 & 0.325 & 0.6 & 18.9 & 2.1 \\
\hline & & Ill & Step 5 & Clay minerals \& phosphates & 5.99 & 7.7 & 107.7 & 12.9 & 6.5 & 12.7 & 114.2 & 12.9 \\
\hline & & Gib & Step 6 & Silicates \& residue & 0.5 & 0.6 & 4.47 & 0.5 & 0.6 & 1.2 & 5.07 & 0.6 \\
\hline & & & - & Residue & 24.8 & 31.9 & 247.4 & 29.7 & 8.44 & 16.5 & 255.9 & 28.9 \\
\hline & & & Step 1 & Ion exchangeable minerals & 85.0 & 81.0 & 608.4 & 61.6 & 52.93 & 81.4 & 661.3 & 62.9 \\
\hline & & Qtz & Step 2 & Organic materials & 2.92 & 2.8 & 19.04 & 1.9 & 1.848 & 2.8 & 20.9 & 2.0 \\
\hline & & $\mathrm{Kfs}$ & Step 3 & Amorphous $\mathrm{Fe}$ oxides \& Mn oxides & 1.96 & 1.9 & 34.03 & 3.4 & 1.553 & 2.4 & 35.6 & 3.4 \\
\hline $70307 \mathrm{~B} 1$ & Weathered & Kln & Step 4 & $\mathrm{Fe} \& \mathrm{Mn}$ oxides & 0.463 & 0.4 & 28.62 & 2.9 & 0.476 & 0.7 & 29.1 & 2.8 \\
\hline & & Ill & Step 5 & Clay minerals \& phosphates & 8.54 & 8.1 & 146.7 & 14.9 & 9.1 & 14.0 & 155.8 & 14.8 \\
\hline & & Gib & Step 6 & Silicates \& residue & 2.7 & 2.6 & 29.9 & 3.0 & 3.0 & 4.6 & 32.9 & 3.1 \\
\hline & & & - & Residue & 3.4 & 3.3 & 120.2 & 12.2 & n.v. & n.v. & 116.3 & 11.1 \\
\hline & & & Step 1 & Ion exchangeable minerals & 54.4 & 36.3 & 873.7 & 45.9 & 53.84 & 51.4 & 927.5 & 46.2 \\
\hline & & Qtz & Step 2 & Organic materials & 1.58 & 1.1 & 18.79 & 1.0 & 1.346 & 1.3 & 20.1 & 1.0 \\
\hline & & $\mathrm{Kfs}$ & Step 3 & Amorphous $\mathrm{Fe}$ oxides \& Mn oxides & 1.80 & 1.2 & 42.29 & 2.2 & 1.906 & 1.8 & 44.2 & 2.2 \\
\hline $70307 \mathrm{~B} 2$ & Weathered & $\mathrm{K} \ln$ & Step 4 & Fe $\&$ Mn oxides & 1.54 & 1.0 & 86.33 & 4.5 & 1.576 & 1.5 & 87.9 & 4.4 \\
\hline & granitic rock & Ill & Step 5 & Clay minerals \& phosphates & 30.0 & 20.0 & 447.8 & 23.5 & 26.7 & 25.5 & 474.5 & 23.6 \\
\hline & & & Step 6 & Silicates \& residue & 5.0 & 3.3 & 51.1 & 2.7 & 4.3 & 4.1 & 55.4 & 2.8 \\
\hline & & & - & Residue & 55.7 & 37.1 & 383.1 & 20.1 & 15.2 & 14.5 & 398.2 & 19.8 \\
\hline & & & Step 1 & Ion exchangeable minerals & 43.3 & 26.4 & 1005.1 & 28.5 & 46.24 & 32.4 & 1051.3 & 28.7 \\
\hline & & & Step 2 & Organic materials & 2.23 & 1.4 & 44.15 & 1.3 & 2.104 & 1.5 & 46.3 & 1.3 \\
\hline & & $\mathrm{Kfs}$ & Step 3 & Amorphous $\mathrm{Fe}$ oxides \& Mn oxides & 4.84 & 3.0 & 96.64 & 2.7 & 4.665 & 3.3 & 101.3 & 2.8 \\
\hline $70307 \mathrm{C}$ & Weathered & Kln & Step 4 & $\mathrm{Fe} \& \mathrm{Mn}$ oxides & 2.10 & 1.3 & 59.18 & 1.7 & 2.010 & 1.4 & 61.2 & 1.7 \\
\hline & & Ill & Step 5 & Clay minerals \& phosphates & 51.4 & 31.3 & 1413.6 & 40.1 & 53.2 & 37.3 & 1466.8 & 40.0 \\
\hline & & & Step 6 & Silicates \& residue & 12.6 & 7.7 & 324.9 & 9.2 & 12.4 & 8.7 & 337.3 & 9.2 \\
\hline & & & - & Residue & 4.75 & 29.0 & 578.2 & 16.4 & 22.0 & 15.4 & 600.2 & 16.4 \\
\hline
\end{tabular}

*1 See text for the reagent and experimental condition at each step of the leaching.

*2 Proportion of the concentration at each step to the concentration of the whole-rock analysis.

*3 Determined by subtracting the concentration of step $1-6$ from the concentration of the whole-rock analysis.

Abbreviations: Qtz=quartz, Kfs=K-feldspar, Kln=kaolin, Ill=illite, Gib=gibbsite, n.a.=not analyzed, n.v.=negative value 
(P797CN1), which is enriched in HREE, also contains zircon and xenotime as the host minerals of HREE. The A and B horizons may be slightly enriched in REE, but all the samples in the Boneng district tend to be less enriched or depleted in REE relative to the parent rocks. These results suggest that no potential for ionadsorption type REE mineralization in this district although the granitic rocks are most enriched in HREE in the studied area of Laos.

\subsubsection{Nape district}

The A and B horizons of weathered crusts in Nape are not remarkably different from the parent rocks in regard to the REE patterns (Fig. 5C) and the changes in REE (Fig. 6C). The weak enrichment of HREE is recognized in the $\mathrm{A}$ and $\mathrm{B}$ horizons. In contrast, the $\mathrm{C}$ horizon is slightly enriched in REE with 205 ppm on average. The enrichment of REE relative to the parent rocks ( $\sum \mathrm{REE}$ $=179 \mathrm{ppm}$ ) is only $+14 \%$ and LREE is more enriched than HREE. In the $\mathrm{C}$ horizon, the most dominant clay minerals are illite rather than kaolin, suggesting the low potential for ion-adsorption type REE mineralization. The sediment samples are depleted in REE and the enrichment of HREE relative to LREE is probably due to residual zircon (Fig. 6C). Thus, the ion-adsorption type REE mineralization is hardly identified in the Nape district.

\subsubsection{Xaisomboun district}

In the Xaisomboun district, the A horizons are depleted in REE, and in contrast, the B horizons are enriched in REE relative to the parent rocks (Fig. 6D). The enrichment of HREE relative to LREE in both horizons is probably derived from the occurrence of residual minerals, which is indicated by the enrichment of $\mathrm{Zr}$, Th and U (Fig. 6D). The REE contents range from 37 to $408 \mathrm{ppm}$ with the average value of 145 ppm, which are not sufficient for REE resources. On the contrary, samples 70307A, B1, B2 and C, which show distinctly high REE contents (885 - 3664 ppm) with the enrichment of LREE relative to HREE (LREE/ HREE = 18.6), were identified in this district. This weathered crust contains kaolin, illite and gibbsite with small amounts of REE-phosphates, which are detected using an electron probe micro analyzer (Fig. 4). The occurrence of these phosphates is also recognized by high $\mathrm{P}_{2} \mathrm{O}_{5}$ contents in the result of bulk-rock analysis (Fig. 8C). The REE-phosphate in this weathered crust is poor in Th (Fig. 8D), suggesting the occurrence of secondary form of monazite and/or rhabdophane (Sawka et al., 1986; Mariano, 1989). The result of sequential leaching indicates that the dominant host minerals of REE are ion-exchangeable clay minerals with minor amounts of phosphates and poorly-soluble minerals in the A and B horizons at this weathered crust (Table 2). In the $\mathrm{C}$ horizon, more REE occurs in phosphates than ion-exchangeable clay minerals. This difference in the proportion of exchangeable REE is attributed to the degree of weathering as shown by CIA value (Fig. 8A). These results indicate that the dominant host minerals of REE in this REE-rich weathered crust are ion-exchangeable clay minerals (probably kaolin) and REE minerals such as monazite and rhabdophane.

\subsubsection{All the rock samples}

The B horizon of weathered crust is most commonly enriched in REE in all of the districts although the $C$ horizon enriched in REE is only found in the Nape district (Fig. 6C). This result is concordant with the fact that the enrichment of REE in the $\mathrm{B}$ horizon and less enrichment of REE in the $\mathrm{A}$ and $\mathrm{C}$ horizons occur in ion-adsorption type deposits, southern China (Wu et al., 1990; Bao and Zhao, 2008). Murakami and Ishihara (2008) reported that the most REE-enriched layers are the B horizon of the weathered Dabu Granite and the C horizon in the weathered Dingnan Granite in southern China. These results indicate that enrichment of REE occurs mostly in the B horizon and subordinately in the $\mathrm{C}$ horizon. In the studied district of Laos, the enrichment of REE in the $\mathrm{B}$ horizon relative to the parent rock is determined to be $+52 \%$ with the range from -69 to $+391 \%$. This value is apparently lower than the average value of $+164 \%$ with the range from +26 to $380 \%$, which was determined by REE contents of weathered crusts and parent rocks in ion-adsorption type deposits (Wu et al., 1990; Bao and Zhao, 2008).

The average LREE/HREE ratio in all the $\mathrm{B}$ horizons and granitic rocks are 10.9 and 9.39, respectively. Although these ratios show that the B horizon appears to be slightly depleted in HREE compared with the parent rocks, the elevated LREE/HREE ratio of the $B$ horizons results from the LREE-enriched samples in the Attapu district (Appendix 1). If these samples are excluded, the LREE/HREE ratio of the B horizons changes to 8.27 , which is slightly smaller than the ratio of the parent rocks. The difference in LREE/ HREE ratios in weathered crusts may be attributed to the degree of alteration. Nesbitt (1979) reported that HREE are enriched by the degree of alteration in granodiorite whereas they are depleted in intensively altered zone. An experimental study also indicated that more HREE are selectively adsorbed on kaolinite and smectite at high ionic strength (Coppin et al., 2002). The result of the present study also indicates that HREE are enriched on ion-exchangeable clay minerals in the weathered rock samples (Table 2). This fractionation between HREE and LREE suggests that HREE are more selectively adsorbed on the ion-exchangeable clay minerals than LREE in the process of weathering. The $\mathrm{C}$ horizon appears to be enriched in LREE (LREE/HREE $=16.3$ ) due to the highly LREE-enriched samples in the Attapu district (Appendix 1). The average LREE/HREE 
ratio except for the samples in the Attapu district is 9.89, which is close to the ratio of the parent rocks. Thus, it is concluded that the B horizon is generally enriched in HREE relative to LREE among the weathered rock samples in the studied districts.

Sediment samples commonly show the depletion of REE and the enrichment of HREE relative to LREE. The enrichment of HREE relative to LREE is derived from the concentration of zircon which is suggested by the enrichment of $\mathrm{Zr}$ (Figs 6B and 6C; Fig. 8E). Murakami and Ishihara (2008) argued that the enrichment of REE in sediment samples derived from the occurrence of clay minerals such as kaolin for REE, and the presence of both clay minerals and zircon for HREE. In the sediment samples of Laos, such enrichment of REE is not recognized. The depletion of REE in the sediments probably results from dilution of REE by the mixing with sediments and/or reworked weathered granitic rocks.

\section{Conclusions}

Most granitic rocks distributed in central and southern Laos are granodiorite and granite showing low to moderate REE contents. The enrichment of LREE with the depletion of HREE in the granitic rocks compared with granite in the southwest Japan and southern China is derived from poorly differentiated magma for granite.

Weathered crusts of the granitic rocks are well developed and contain abundant clay minerals such as kaolin and illite, but they are not sufficiently enriched in REE for resources. The B horizon, which is the most prospective horizon, is slightly or moderately enriched in REE and HREE relative to the parent rock whereas the $\mathrm{A}$ and $\mathrm{C}$ horizons are depleted or less enriched in REE. Kaolin-rich rocks and sediment samples in the granite area mostly show lower REE contents.

Prospective weathered crusts of granitic rocks for REE resources are locally identified in the Attapu and Xaisomboun districts. These weathered crusts have the ion-adsorption type REE mineralization with the occurrence of REE phosphates such as monazite and rhabdophane. The result of sequential leaching suggests that HREE are selectively adsorbed on ionexchangeable clay minerals than LREE in the process of weathering.

Acknowledgment: We acknowledge Mr. Khampha Phommakaysone in the Department of Geology, Ministry of Energy and Mines for giving a permission to conduct the fieldwork for this study. We are grateful to Dr. Yoshimitsu Negishi and Mr. Motomu Goto in the Mitsubishi Materials Techno Co., Ltd. for helpful advices.

\section{References}

Bao, Z. and Zhao, Z. (2008) Geochemistry of mineralization with exchangeable REY in the weathering crusts of granitic rocks in South China. Ore Geol. Rev., 33, 519-535.

Castor, S.B. (2008) Rare Earth Deposits of North America. Resource Geol., 58, 337-347.

Cerny, P., Blevin, P., Cuney, M. and London, D. (2005) Granite-related ore deposits. Econ. Geol. 100th Anniversary Volume, 337-370.

Coppin, F., Berger, G., Bauer, A., Castet, S. and Loubet, M. (2002) Sorption of lanthanides on smectite and kaolinite. Chemical Geol., 182, 57-68.

DGM (Department of Geology and Mine, Lao P.D.R.) (1991) Geological and Mineral Occurrence Map. 1:100,000 scale. British Geological Survey and Department of Geology and Mines.

DGM (Department of Geology and Mine, Lao PDR) (2000) Report: Geology and Minerals of MidCentral Laos Region, Part 1 General Geology (scale 1:200,000) In Tran van Ban, ed., Vientiane, $300 \mathrm{p}$.

ESCAP (United Nations Economic and Social Commision for Asia and the Pacific) (1990) Atlas of Mineral Resources of the ESCAP Region. v. 7, Explanatory Brochure, United Nations, 19p.

FAO (Food and Agriculture Organization of the United Nations Office) (2003) AQUASTAT2003

Ferrari, O.M., Hochard, C., Stampfli, G.M. (2008) An alternative plate tectonic model for the PalaeozoicEarly Mesozoic Palaeotethyan evolution of Southeast Asia (Northern Thailand-Burma). Tectonophysics, 451, 346-365.

Henderson, P. (1984) Rare Earth Element Geochemistry, Elsevier, Amsterdam, 510p.

Huang, D., Wu, C. and Han, J. (1989) REE geochemistry and mineralization characteristics of the Zudong and Guanxi granites, Jaingxi Province. Acta Geol. Sinica, 2, 139-157.

Hutchison, C. S. (1989) Geological Evolution of SouthEast Asia. Oxford Monographs on Geology and Geophysics, v. 13, Clarendon Press, Oxford, UK, $368 \mathrm{p}$.

Industrial Rare Metals (2008) Rare Earth, Annual Review 2008. Industrial Rare Metals, 124, 53-56.

Ishihara, S. and Murakami, H. (2006) Fractionated ilmenite-series granitic rocks in Southwest Japan: Source magma for REE-Sn-W mineralization. Resource Geol., 56, 245-256.

Lehmann, B. and Mahawat, C. (1989) Metallogeny of tin in central Thailand: A genetic concept. Geology, 17, 426-429.

Mariano, A. N. (1989) Economic geology of rare earth minerals. In B.R. Lipin, and G.A. Mckay, eds., Geochemistry and Mineralogy of Rare 
Earth Elements (Reviews in Mineralogy, v. 21), Mineralogical Society of America, Washington D.C., 309-338.

Murakami, H. and Ishihara, S. (2008) REE mineralization of weathered crust and clay sediment on granitic rocks in the Sanyo belt, SW Japan and southern Jiangxi province, China. Resource Geol., 58, 373-401.

Nesbitt, H.W. (1979) Mobility and fractionation of rare earth elements during weathering of a granodiorite. Nature, 279, 206-210.

Nesbitt, H.W. and Young, G.M. (1982) Early Proterozoic climates and plate motions inferred from major element geochemistry of lutites. Nature, 299, 715-717.

Osanai, Y., Nakano, N., Owada, M. Tran Ngoc Nam, Miyamoto, T., Nguyen Thi Minh, Nguyen Van Nam and Tran Van Tri (2008) Collision zone metamorphism in Vietnam and adjacent Southeastern Asia: Proposition for Trans Vietnam Orogenic Belt. Jour. Mineral. Petrol. Science, 103, 226-241

Owada, M., Osanai, Y., Nakano, N., Matsushita, T., Tran Ngoc Nam, Tsunogae, T., Toyoshima, T. Pham Binh, Kagami, H. (2007) Crustal anatexis and formation of two types of granitic magmas in the Kontum massif, central Vietnam: Implications for magima processes in collision zones. Gondwana Res., 12, 428-437.

Roskill (2007) The Economics of Rare Earths and Yttrium, 13th edition, 2007. Roskill Information Services, Ltd, London. 275p.

Sawka, W.N., Banfield, J.F. and Chappell, B.W. (1986) A weathering-related origin of widespread monazite in S-type granites. Geochimi. Cosmochimi. Acta, 50, 171-175.
Sun, S.S. and McDonough, W.F. (1989) Chemical and isotopic systematics of oceanic basalts: implications for mantle composition and processes. In Saunders, A.D. and Norry, M.J., eds., Magmatism in the Ocean Basins (Geological Society Special Publication, no. 42), 313-345.

Vilayhack, S., Duangsurigna, S., Phomkenthao, S., Voravong, A., Vilaysan, P., Khounchanthida, T., Phommakaysone, K. Goto, M., Negishi, Y., Tsuda, K., Watanabe, Y. and Shibata, Y. (2008) 1:200,000 Geological Map of B.Dakyoy with Report on Geology of the B.Dakyoy District. Japan International Cooperation Agency and Department of Geology, Ministry of Energy and Mines, Lao P.D.R., 44p.

Wu, C. (2008) Bayan Obo controversy: Carbonatites versus iron oxide-Cu-Au-(REE-U), Resource Geol., 58, 348-354.

Wu, C., Huang, D. and Guo, Z. (1990) REE geochemistry in the weathered crust of granites, Longnan area, Jiangxi province. Acta Geol. Sinica, 3, 193-210.

Wu, C, Yuan, Z. and Bai, G. (1996) Rare earth deposits in China. In Jones, A.P., Wall, F. and Williams, C.T., eds., Rare Earth Minerals: Chemistry origin and ore deposits (The Mineralogical Society Series, 7), Chapman\&Hall, 281-310.

Yang, Y., Hu, Z. and Luo, Z. (1981) Geological characteristics of ion-adsorption type rare earth deposits and their prospecting direction. Bull. Inst. Miner. Deposit Chin. Acad. Geol. Sci., 1, 102-118 (in Chinese with English abstract).

Received March, 10, 2009

Accepted May, 28, 2009 
Appendix 1 Chemical composition of major and trace elements in studied rock samples.

\begin{tabular}{|c|c|c|c|c|c|c|c|c|c|c|}
\hline Sequential \# & 1 & 2 & 3 & 4 & 5 & 6 & 7 & 8 & 9 & 10 \\
\hline Sample \# & P712 & P725 & P726 & P793 & 62701 & 62702 & 62703 & 62801 & 62802 & 62809 \\
\hline District & Attapu & Attapu & Attapu & Attapu & Boneng & Boneng & Boneng & Boneng & Boneng & Boneng \\
\hline Rock type & Bt Grd & Hbl-Bt Grd & Hbl-Bt Grd & Bt Grd & $\mathrm{Bt} \mathrm{Gr}(\mathrm{F})$ & $\mathrm{Bt} \mathrm{Gr}(\mathrm{F})$ & $\mathrm{Bt} \mathrm{Gr}(\mathrm{F})$ & $\mathrm{Bt} \mathrm{Gr}$ & $\mathrm{Bt} \mathrm{Gr}$ & Bt Gr Por \\
\hline Latitude & $14^{\circ} 47.027^{\prime}$ & $14^{\circ} 49.306^{\prime}$ & $14^{\circ} 49.794^{\prime}$ & $14^{\circ} 49.576^{\prime}$ & $17^{\circ} 55.131^{\prime}$ & $17^{\circ} 55.979^{\prime}$ & $17^{\circ} 55.979^{\prime}$ & $17^{\circ} 58.746^{\prime}$ & $17^{\circ} 58.746^{\prime}$ & $17^{\circ} 58.876^{\prime}$ \\
\hline Longitude & $107^{\circ} 30.168^{\prime}$ & $107^{\circ} 22.1^{\prime}$ & $107^{\circ} 21.394^{\prime}$ & $107^{\circ} 27.649^{\prime}$ & $104^{\circ} 33.493^{\prime}$ & $104^{\circ} 32.309^{\prime}$ & $104^{\circ} 32.309^{\prime}$ & $104^{\circ} 18.529^{\prime}$ & $104^{\circ} 18.529^{\prime}$ & $104^{\circ} 18.467^{\prime}$ \\
\hline $\mathrm{SiO}_{2}(\mathrm{wt} \%)$ & 69.18 & 65.15 & 65.64 & 66.55 & 70.53 & 71.74 & 72.33 & 70.15 & 71.34 & 72.57 \\
\hline $\mathrm{TiO}_{2}$ & 0.31 & 0.60 & 0.54 & 0.51 & 0.31 & 0.17 & 0.16 & 0.32 & 0.32 & 0.34 \\
\hline $\mathrm{Al}_{2} \mathrm{O}_{3}$ & 16.4 & 15.01 & 15.25 & 15.43 & 14.31 & 13.18 & 13.65 & 14.15 & 13.03 & 13.37 \\
\hline $\mathrm{Fe}_{2} \mathrm{O}_{3} *$ & 2.59 & 4.74 & 4.27 & 3.97 & 2.57 & 2.18 & 2.22 & 2.69 & 2.70 & 3.12 \\
\hline $\mathrm{MnO}$ & 0.034 & 0.076 & 0.073 & 0.062 & 0.039 & 0.050 & 0.045 & 0.021 & 0.018 & 0.048 \\
\hline $\mathrm{MgO}$ & 0.94 & 1.55 & 1.42 & 1.21 & 0.64 & 0.28 & 0.29 & 0.31 & 0.33 & 0.49 \\
\hline $\mathrm{CaO}$ & 2.62 & 3.01 & 3.04 & 2.68 & 1.55 & 0.66 & 0.63 & 0.27 & 0.21 & 0.46 \\
\hline $\mathrm{Na}_{2} \mathrm{O}$ & 4.68 & 2.63 & 2.82 & 2.72 & 3.08 & 3.12 & 3.21 & 2.55 & 3.39 & 4.16 \\
\hline $\mathrm{K}_{2} \mathrm{O}$ & 1.86 & 5.15 & 4.91 & 5.03 & 4.55 & 4.84 & 4.99 & 4.36 & 4.00 & 3.99 \\
\hline $\mathrm{P}_{2} \mathrm{O}_{5}$ & 0.08 & 0.24 & 0.21 & 0.23 & 0.14 & 0.12 & 0.12 & 0.05 & 0.05 & 0.08 \\
\hline LOI & 0.89 & 0.90 & 1.12 & 1.08 & 1.09 & 1.28 & 1.17 & 3.06 & 2.03 & 1.22 \\
\hline Total & 99.59 & 99.07 & 99.29 & 99.49 & 98.79 & 97.60 & 98.80 & 97.91 & 97.42 & 99.82 \\
\hline $\mathrm{F}(\mathrm{wt} \%)$ & n.a. & n.a. & n.a. & n.a. & 0.11 & 0.16 & 0.16 & 0.04 & 0.04 & 0.05 \\
\hline ASI & 1.13 & 0.98 & 0.99 & 1.04 & 1.12 & 1.14 & 1.15 & 1.5 & 1.27 & 1.11 \\
\hline CIA (\%) & 53.1 & 49.4 & 49.6 & 51.1 & 52.8 & 53.2 & 53.6 & 60.1 & 55.9 & 52.7 \\
\hline $\mathrm{Rb}$ (ppm) & 61 & 176 & 196 & 215 & 204 & 244 & 263 & 131 & 115 & 122 \\
\hline $\mathrm{Sr}$ & 870 & 250 & 222 & 339 & 204 & 83 & 82 & 77 & 92 & 96 \\
\hline Cs & 1.3 & 5.9 & 6.0 & 4.3 & 10.8 & 8.6 & 9.1 & 2.1 & 1.5 & 1.6 \\
\hline $\mathrm{Ba}$ & 435 & 1410 & 1220 & 1390 & 777 & 301 & 291 & 1080 & 1090 & 875 \\
\hline Sn & 2 & 3 & 3 & 3 & 5 & 5 & 6 & 7 & 4 & 4 \\
\hline $\mathrm{Zr}$ & 156 & 247 & 233 & 296 & 154 & 116 & 117 & 249 & 241 & 252 \\
\hline Hf & 4.0 & 6.2 & 6.2 & 7.9 & 5.1 & 4.3 & 4.3 & 7.4 & 7.0 & 7.5 \\
\hline $\mathrm{Nb}$ & 10 & 10 & 12 & 12 & 13 & 14.2 & 15.1 & 14.1 & 13.4 & 19.1 \\
\hline $\mathrm{Ta}$ & 0.6 & 0.8 & 1.0 & 0.6 & 1.44 & 1.53 & 1.52 & 1.45 & 1.28 & 1.66 \\
\hline V & 24 & 68 & 62 & 61 & 24 & 9 & 8 & 16 & 14 & 15 \\
\hline Co & 4 & 8 & 8 & 7 & 4 & 79 & 66 & 57 & 65 & 65 \\
\hline $\mathrm{Zn}$ & 30 & 40 & 50 & 50 & 120 & 60 & 40 & 50 & 50 & 60 \\
\hline $\mathrm{Ga}$ & 19 & 14 & 15 & 17 & 21 & 20 & 21 & 18 & 16 & 18 \\
\hline $\mathrm{Ge}$ & 1 & 1 & 1 & 1 & 2 & 2 & 2 & 1 & 1 & 1 \\
\hline $\mathrm{Pb}$ & 13 & 23 & 35 & 22 & 39 & 29 & 28 & 28 & 24 & 25 \\
\hline Th & 2.6 & 23.4 & 34.8 & 30.6 & 18.2 & 14.8 & 15.6 & 18.8 & 15.3 & 19.0 \\
\hline $\mathrm{U}$ & 1.7 & 6.6 & 5.9 & 4.1 & 5.30 & 4.22 & 4.23 & 2.91 & 2.45 & 3.10 \\
\hline $\mathrm{Y}$ & 7 & 19 & 22 & 19 & 34.1 & 30.9 & 34.7 & 41.6 & 33.9 & 51.8 \\
\hline $\mathrm{La}$ & 8.3 & 30.5 & 62.6 & 52.1 & 41.1 & 25.6 & 26.8 & 97.3 & 76.7 & 75.9 \\
\hline $\mathrm{Ce}$ & 14.3 & 69.1 & 121 & 97.1 & 82.0 & 53.6 & 57.8 & 122 & 87.2 & 114 \\
\hline $\operatorname{Pr}$ & 1.42 & 7.96 & 12.6 & 9.55 & 10.1 & 6.96 & 7.55 & 19.8 & 16.8 & 15.5 \\
\hline $\mathrm{Nd}$ & 5.3 & 28.4 & 41.4 & 30.3 & 34.3 & 26.2 & 28.9 & 57.1 & 48.4 & 45.9 \\
\hline $\mathrm{Sm}$ & 1.2 & 5.6 & 7.7 & 6.0 & 6.60 & 5.69 & 6.45 & 10.6 & 8.82 & 8.53 \\
\hline $\mathrm{Eu}$ & 0.86 & 1.41 & 1.47 & 1.62 & 0.994 & 0.492 & 0.509 & 1.60 & 1.35 & 1.17 \\
\hline $\mathrm{Gd}$ & 1.3 & 4.8 & 6.2 & 5.0 & 6.54 & 6.10 & 6.75 & 9.78 & 7.87 & 8.26 \\
\hline $\mathrm{Tb}$ & 0.2 & 0.6 & 0.8 & 0.7 & 1.09 & 1.05 & 1.15 & 1.55 & 1.20 & 1.36 \\
\hline Dy & 1.0 & 3.1 & 4.1 & 3.7 & 5.9 & 5.6 & 6.3 & 7.86 & 6.34 & 7.39 \\
\hline Но & 0.2 & 0.6 & 0.8 & 0.7 & 1.10 & 0.94 & 1.05 & 1.45 & 1.19 & 1.50 \\
\hline $\mathrm{Er}$ & 0.6 & 1.7 & 2.2 & 1.9 & 3.08 & 2.42 & 2.74 & 4.19 & 3.72 & 4.50 \\
\hline $\mathrm{Tm}$ & 0.09 & 0.26 & 0.32 & 0.27 & 0.450 & 0.324 & 0.368 & 0.637 & 0.584 & 0.692 \\
\hline $\mathrm{Yb}$ & 0.6 & 1.7 & 2.0 & 1.6 & 2.68 & 1.82 & 2.04 & 4.07 & 3.83 & 4.29 \\
\hline $\mathrm{Lu}$ & 0.10 & 0.24 & 0.28 & 0.23 & 0.370 & 0.223 & 0.257 & 0.593 & 0.562 & 0.647 \\
\hline$\Sigma$ LREE & 31.4 & 143.0 & 246.8 & 196.7 & 175.1 & 118.5 & 128.0 & 308.4 & 239.3 & 261.0 \\
\hline$\Sigma$ HREE & 4.1 & 13.0 & 16.7 & 14.1 & 21.2 & 18.5 & 20.7 & 30.1 & 25.3 & 28.6 \\
\hline$\Sigma$ REE & 35.5 & 156.0 & 263.5 & 210.8 & 196.3 & 137.0 & 148.7 & 338.5 & 264.6 & 289.6 \\
\hline$\Sigma \mathrm{REE}+\mathrm{Y}$ & 42.5 & 175.0 & 285.5 & 229.8 & 230.4 & 167.9 & 183.4 & 380.1 & 298.5 & 341.4 \\
\hline LREE/HREE & 7.7 & 11.0 & 14.8 & 13.9 & 8.3 & 6.4 & 6.2 & 10.2 & 9.5 & 9.1 \\
\hline HREE/REE & 0.12 & 0.08 & 0.06 & 0.07 & 0.11 & 0.13 & 0.14 & 0.09 & 0.10 & 0.10 \\
\hline $\mathrm{Ce} / \mathrm{Ce}^{*}$ & 1.02 & 1.09 & 1.06 & 1.07 & 0.99 & 0.98 & 1.00 & 0.68 & 0.60 & 0.81 \\
\hline $\mathrm{Eu} / \mathrm{Eu}^{*}$ & 2.11 & 0.83 & 0.65 & 0.90 & 0.46 & 0.26 & 0.24 & 0.48 & 0.50 & 0.43 \\
\hline $\mathrm{La}_{\mathrm{N}} / \mathrm{Yb}_{\mathrm{N}}$ & 9.9 & 12.9 & 22.5 & 23.4 & 11.0 & 10.1 & 9.4 & 17.1 & 14.4 & 12.7 \\
\hline $\mathrm{Rb} / \mathrm{Sr}$ & 0.07 & 0.70 & 0.88 & 0.63 & 1.00 & 2.94 & 3.21 & 1.70 & 1.25 & 1.27 \\
\hline
\end{tabular}

$\mathrm{Fe}_{2} \mathrm{O}_{3}^{*}=$ Total iron oxides

$\mathrm{ASI}=$ Alumina saturation index determined by molecular proportion of $\mathrm{Al}_{2} \mathrm{O}_{3} /\left(\mathrm{Na}_{2} \mathrm{O}+\mathrm{K}_{2} \mathrm{O}+\mathrm{CaO}\right)$.

$\mathrm{CIA}=$ Cemical index of alteration determined by molecular proportion of $\left[\mathrm{Al}_{2} \mathrm{O}_{3} /\left(\mathrm{Al}_{2} \mathrm{O}_{3}+\mathrm{CaO}+\mathrm{Na}_{2} \mathrm{O}+\mathrm{K}_{2} \mathrm{O}\right)\right]_{-} 100$, where $\mathrm{CaO}$ is not from carbonate.

$\mathrm{Ce} / \mathrm{Ce}^{*}=\mathrm{Ce}_{\mathrm{N}} /\left(\mathrm{La}_{\mathrm{N}} \times \mathrm{Pr}_{\mathrm{N}}\right)^{1 / 2}$, where $\mathrm{N}$ is normalized by chondrite.

$\mathrm{Eu} / \mathrm{Eu}^{*}=\mathrm{Eu}_{\mathrm{N}} /\left(\mathrm{Sm}_{\mathrm{N}} \times \mathrm{Gd}_{\mathrm{N}}\right)^{1 / 2}$, where $\mathrm{N}$ is normalized by chondrite.

Abbreviations: $\mathrm{Bt}=$ biotite, $\mathrm{Hbl}=$ hornblende, $\mathrm{Ms}=$ muscovite, Tur=tourmaline, $\mathrm{Gr}=$ granite, $\mathrm{Grd}=$ granodiorite, Por-porphyry, $\mathrm{F})=$ float

W Gr=weathered granitic rock, Kln-rich=Kaolin-rich rock, Conc=concentrate, n.a. =not analyzed 
Appendix 1 Continued.

\begin{tabular}{|c|c|c|c|c|c|c|c|c|c|c|}
\hline $\begin{array}{l}\text { Sequential \# } \\
\text { Sample \# }\end{array}$ & $\begin{array}{c}11 \\
62814 \\
\end{array}$ & $\begin{array}{c}12 \\
62815 \\
\end{array}$ & $\begin{array}{c}13 \\
62818 \\
\end{array}$ & $\begin{array}{c}14 \\
62901 \\
\end{array}$ & $\begin{array}{c}15 \\
62903 \\
\end{array}$ & $\begin{array}{c}16 \\
63001 \\
\end{array}$ & $\begin{array}{c}17 \\
63002 \\
\end{array}$ & $\begin{array}{c}18 \\
63005 \\
\end{array}$ & $\begin{array}{c}19 \\
70101 \\
\end{array}$ & $\begin{array}{c}20 \\
70102 \\
\end{array}$ \\
\hline District & Boneng & Boneng & Boneng & Nape & Nape & Nape & Nape & Nape & Nape & Nape \\
\hline Rock type & $\mathrm{Bt} \mathrm{Gr}$ & Greisen (F) & Tur Gr (F) & Bt Grd & Bt Grd & Ms-Bt Gr & Bt Grd & Bt Grd & Bt Grd & Bt Grd \\
\hline Latitude & $18^{\circ} 10.226^{\prime}$ & $18^{\circ} 10.226^{\prime}$ & $18^{\circ} 10.239^{\prime}$ & $18^{\circ} 12.065^{\prime}$ & $18^{\circ} 12.065^{\prime}$ & $18^{\circ} 09.492^{\prime}$ & $18^{\circ} 09.492^{\prime}$ & $18^{\circ} 17.431^{\prime}$ & $18^{\circ} 18.552^{\prime}$ & $18^{\circ} 18.811^{\prime}$ \\
\hline Longitude & $104^{\circ} 17.097^{\prime}$ & $104^{\circ} 17.097^{\prime}$ & $104^{\circ} 17.118^{\prime}$ & $105^{\circ} 08.174^{\prime}$ & $105^{\circ} 08.174^{\prime}$ & $105^{\circ} 12.102^{\prime}$ & $105^{\circ} 12.102^{\prime}$ & $105^{\circ} 04.013^{\prime}$ & $105^{\circ} 05.671^{\prime}$ & $105^{\circ} 06.107^{\prime}$ \\
\hline $\mathrm{SiO}_{2}(\mathrm{wt} \%)$ & 66.96 & 75.42 & 78.55 & 68.77 & 67.29 & 72.06 & 69.60 & 68.95 & 66.39 & 67.74 \\
\hline $\mathrm{TiO}_{2}$ & 0.50 & 0.05 & 0.09 & 0.27 & 0.54 & 0.13 & 0.52 & 0.28 & 0.41 & 0.49 \\
\hline $\mathrm{Al}_{2} \mathrm{O}_{3}$ & 14.90 & 14.10 & 9.75 & 15.07 & 14.95 & 14.37 & 14.37 & 14.38 & 15.34 & 14.28 \\
\hline $\mathrm{Fe}_{2} \mathrm{O}_{3} *$ & 3.98 & 1.10 & 4.48 & 2.52 & 4.08 & 1.25 & 3.57 & 2.87 & 3.63 & 3.84 \\
\hline $\mathrm{MnO}$ & 0.057 & 0.028 & 0.051 & 0.056 & 0.055 & 0.018 & 0.059 & 0.070 & 0.056 & 0.055 \\
\hline $\mathrm{MgO}$ & 0.96 & 0.17 & 0.39 & 0.70 & 1.49 & 0.27 & 1.00 & 0.73 & 1.10 & 1.46 \\
\hline $\mathrm{CaO}$ & 2.24 & $<0.01$ & 0.06 & 1.75 & 3.44 & 0.46 & 2.11 & 0.98 & 2.50 & 2.25 \\
\hline $\mathrm{Na}_{2} \mathrm{O}$ & 3.10 & 0.27 & 0.48 & 2.68 & 2.69 & 3.20 & 2.81 & 2.41 & 3.05 & 2.51 \\
\hline $\mathrm{K}_{2} \mathrm{O}$ & 4.31 & 4.22 & 0.13 & 5.43 & 2.75 & 5.04 & 3.92 & 3.73 & 4.33 & 4.35 \\
\hline $\mathrm{P}_{2} \mathrm{O}_{5}$ & 0.19 & 0.02 & 0.01 & 0.14 & 0.29 & 0.26 & 0.18 & 0.14 & 0.15 & 0.16 \\
\hline LOI & 0.97 & 2.34 & 1.03 & 1.24 & 1.09 & 1.29 & 1.20 & 2.77 & 0.81 & 1.01 \\
\hline Total & 98.14 & 97.68 & 94.99 & 98.59 & 98.65 & 98.32 & 99.33 & 97.29 & 97.74 & 98.12 \\
\hline $\mathrm{F}(\mathrm{wt} \%)$ & 0.11 & 0.23 & 0.19 & 0.04 & n.a. & 0.10 & 0.08 & 0.05 & 0.08 & 0.08 \\
\hline ASI & 1.08 & 2.8 & 9.38 & 1.12 & 1.09 & 1.24 & 1.13 & 1.47 & 1.08 & 1.1 \\
\hline CIA (\%) & 51.8 & 73.7 & 90.4 & 52.8 & 52.3 & 55.4 & 53.1 & 59.5 & 51.8 & 52.5 \\
\hline $\mathrm{Rb}$ (ppm) & 192 & 442 & 10 & 209 & 128 & 396 & 186 & 211 & 189 & 226 \\
\hline $\mathrm{Sr}$ & 222 & 6 & 5 & 231 & 358 & 48 & 169 & 131 & 270 & 189 \\
\hline Cs & 10.2 & 32.1 & 0.6 & 5.3 & 6.6 & 21.9 & 9.3 & 8.4 & 7.7 & 9.0 \\
\hline $\mathrm{Ba}$ & 901 & 368 & $<3$ & 747 & 985 & 146 & 777 & 356 & 818 & 630 \\
\hline Sn & 5 & 35 & 6 & 5 & 4 & 15 & 6 & 6 & 25 & 6 \\
\hline $\mathrm{Zr}$ & 244 & 32 & 19 & 112 & 201 & 58 & 175 & 111 & 150 & 190 \\
\hline Hf & 7.3 & 2.7 & 1.6 & 3.7 & 5.8 & 2.2 & 5.4 & 3.9 & 4.7 & 5.7 \\
\hline $\mathrm{Nb}$ & 15.2 & 19.6 & 33.4 & 8.7 & 10.3 & 15.8 & 11.1 & 12.8 & 11.3 & 13.2 \\
\hline $\mathrm{Ta}$ & 1.43 & 6.28 & 10.5 & 1.12 & 0.88 & 3.04 & 1.43 & 1.93 & 1.11 & 1.42 \\
\hline V & 39 & $<5$ & 7 & 30 & 68 & 7 & 42 & 33 & 48 & 52 \\
\hline Co & 64 & 58 & 126 & 55 & 66 & 73 & 68 & 60 & 57 & 71 \\
\hline $\mathrm{Zn}$ & 50 & $<30$ & 120 & 40 & 60 & 40 & 80 & 60 & 60 & 70 \\
\hline $\mathrm{Ga}$ & 22 & 46 & 30 & 17 & 20 & 22 & 20 & 20 & 19 & 20 \\
\hline $\mathrm{Ge}$ & 2 & 3 & 2 & 2 & 1 & 3 & 2 & 2 & 2 & 2 \\
\hline $\mathrm{Pb}$ & 24 & 66 & 5 & 34 & 22 & 31 & 32 & 31 & 38 & 33 \\
\hline Th & 22.4 & 7.37 & 7.90 & 11.8 & 12.1 & 7.07 & 11.7 & 11.9 & 17.0 & 21.7 \\
\hline $\mathrm{U}$ & 4.18 & 9.80 & 8.26 & 2.88 & 2.28 & 10.4 & 4.33 & 4.26 & 3.60 & 5.05 \\
\hline Y & 36.9 & 7.4 & 8.0 & 27.5 & 33.0 & 14.2 & 31.9 & 31.6 & 33.8 & 26.1 \\
\hline $\mathrm{La}$ & 54.0 & 8.2 & 3.49 & 28.8 & 39.1 & 13.1 & 35.8 & 30.0 & 41.6 & 47.5 \\
\hline $\mathrm{Ce}$ & 109 & 20.6 & 9.82 & 58.1 & 75.4 & 28.1 & 70.4 & 59.6 & 83.6 & 96.5 \\
\hline $\operatorname{Pr}$ & 13.4 & 2.71 & 1.51 & 6.94 & 9.18 & 3.46 & 8.6 & 7.26 & 10.0 & 11.4 \\
\hline $\mathrm{Nd}$ & 41.6 & 11.0 & 7.42 & 21.7 & 29.3 & 13.4 & 27.5 & 24.4 & 31.9 & 35.5 \\
\hline $\mathrm{Sm}$ & 8.33 & 2.32 & 1.86 & 4.5 & 5.81 & 3.0 & 5.79 & 5.08 & 6.34 & 6.9 \\
\hline $\mathrm{Eu}$ & 1.42 & 0.322 & 0.256 & 1.20 & 1.79 & 0.413 & 1.4 & 0.961 & 1.49 & 1.17 \\
\hline $\mathrm{Gd}$ & 7.89 & 1.95 & 1.66 & 4.38 & 5.94 & 3.33 & 5.81 & 4.94 & 5.89 & 6.13 \\
\hline $\mathrm{Tb}$ & 1.28 & 0.36 & 0.33 & 0.79 & 1.03 & 0.58 & 1.03 & 0.91 & 1.03 & 0.95 \\
\hline Dy & 6.58 & 1.88 & 1.80 & 4.47 & 5.74 & 2.74 & 5.56 & 5.07 & 5.74 & 4.71 \\
\hline Но & 1.19 & 0.29 & 0.27 & 0.87 & 1.09 & 0.41 & 1.08 & 0.99 & 1.11 & 0.87 \\
\hline $\mathrm{Er}$ & 3.34 & 0.83 & 0.83 & 2.66 & 3.10 & 1.02 & 3.16 & 3.01 & 3.34 & 2.43 \\
\hline $\mathrm{Tm}$ & 0.482 & 0.154 & 0.180 & 0.420 & 0.438 & 0.141 & 0.488 & 0.480 & 0.506 & 0.358 \\
\hline $\mathrm{Yb}$ & 2.89 & 1.14 & 1.42 & 2.61 & 2.60 & 0.84 & 3.19 & 3.10 & 3.17 & 2.18 \\
\hline $\mathrm{Lu}$ & 0.40 & 0.165 & 0.196 & 0.374 & 0.350 & 0.107 & 0.450 & 0.446 & 0.447 & 0.313 \\
\hline$\Sigma$ LREE & 227.8 & 45.2 & 24.4 & 121.2 & 160.6 & 61.5 & 149.5 & 127.3 & 174.9 & 199.0 \\
\hline$\Sigma$ HREE & 24.1 & 6.8 & 6.7 & 16.6 & 20.3 & 9.2 & 20.8 & 18.9 & 21.2 & 17.9 \\
\hline$\Sigma \mathrm{REE}$ & 251.8 & 51.9 & 31.0 & 137.8 & 180.9 & 70.6 & 170.3 & 146.2 & 196.2 & 216.9 \\
\hline$\Sigma \mathrm{REE}+\mathrm{Y}$ & 288.7 & 59.3 & 39.0 & 165.3 & 213.9 & 84.8 & 202.2 & 177.8 & 230.0 & 243.0 \\
\hline LREE/HREE & 9.5 & 6.7 & 3.6 & 7.3 & 7.9 & 6.7 & 7.2 & 6.7 & 8.2 & 11.1 \\
\hline HREE/REE & 0.10 & 0.13 & 0.22 & 0.12 & 0.11 & 0.13 & 0.12 & 0.13 & 0.11 & 0.08 \\
\hline $\mathrm{Ce} / \mathrm{Ce}^{*}$ & 0.99 & 1.07 & 1.05 & 1.01 & 0.98 & 1.02 & 0.98 & 0.99 & 1.00 & 1.02 \\
\hline $\mathrm{Eu} / \mathrm{Eu}^{*}$ & 0.54 & 0.46 & 0.45 & 0.83 & 0.93 & 0.40 & 0.74 & 0.59 & 0.75 & 0.55 \\
\hline $\mathrm{La}_{\mathrm{N}} / \mathrm{Yb}_{\mathrm{N}}$ & 13.4 & 5.2 & 1.8 & 7.9 & 10.8 & 11.2 & 8.0 & 6.9 & 9.4 & 15.6 \\
\hline $\mathrm{Rb} / \mathrm{Sr}$ & 0.86 & 73.67 & 2.00 & 0.90 & 0.36 & 8.25 & 1.10 & 1.61 & 0.70 & 1.20 \\
\hline
\end{tabular}


Appendix 1 Continued.

\begin{tabular}{|c|c|c|c|c|c|c|c|c|c|c|}
\hline Sequential \# & 21 & 22 & 23 & 24 & 25 & 26 & 27 & 28 & 29 & 30 \\
\hline Sample \# & 70105 & 70107 & 70108 & 70109 & 70114 & 70303 & 70304 & 70305 & 70306 & 70402 \\
\hline District & Nape & Nape & Nape & Nape & Nape & Xaisom. & Xaisom. & Xaisom. & Xaisom. & Xaisom. \\
\hline Rock type & Bt Grd (F) & $\mathrm{Bt} \mathrm{Gr}$ & Bt Grd & Bt Grd & Bt Grd & Bt-Hbl Grd & Bt-Hbl Grd (F) & Bt-Hbl Grd (F) & Bt-Hbl Grd (F) & Bt Gr Por \\
\hline Latitude & $18^{\circ} 19.703^{\prime}$ & $18^{\circ} 20.932^{\prime}$ & $18^{\circ} 21.499^{\prime}$ & $18^{\circ} 22.071^{\prime}$ & $18^{\circ} 22.049^{\prime}$ & $18^{\circ} 43.5^{\prime}$ & $18^{\circ} 43.424^{\prime}$ & $18^{\circ} 43.424^{\prime}$ & $18^{\circ} 43.424^{\prime}$ & $18^{\circ} 58.194^{\prime}$ \\
\hline Longitude & $105^{\circ} 06.694^{\prime}$ & $105^{\circ} 07.790^{\prime}$ & $105^{\circ} 8.026^{\prime}$ & $105^{\circ} 8.406^{\prime}$ & $105^{\circ} 2.012^{\prime}$ & $103^{\circ} 15.565^{\prime}$ & $103^{\circ} 18.490^{\prime}$ & $103^{\circ} 18.490^{\prime}$ & $103^{\circ} 18.490^{\prime}$ & $103^{\circ} 18.943^{\prime}$ \\
\hline $\mathrm{SiO}_{2}(\mathrm{wt} \%)$ & 60.36 & 70.45 & 67.92 & 66.34 & 67.14 & 62.75 & 55.29 & 55.80 & 63.16 & 73.40 \\
\hline $\mathrm{TiO}_{2}$ & 0.89 & 0.36 & 0.41 & 0.47 & 0.44 & 0.46 & 0.53 & 0.57 & 0.51 & 0.25 \\
\hline $\mathrm{Al}_{2} \mathrm{O}_{3}$ & 16.29 & 13.73 & 14.55 & 15.66 & 14.80 & 15.56 & 13.88 & 14.01 & 14.59 & 13.20 \\
\hline $\mathrm{Fe}_{2} \mathrm{O}_{3}$ * & 6.27 & 2.49 & 3.28 & 4.24 & 4.04 & 5.89 & 8.80 & 8.65 & 5.44 & 1.68 \\
\hline $\mathrm{MnO}$ & 0.070 & 0.046 & 0.054 & 0.059 & 0.063 & 0.114 & 0.143 & 0.142 & 0.101 & 0.040 \\
\hline $\mathrm{MgO}$ & 2.92 & 0.71 & 1.28 & 1.45 & 1.27 & 2.56 & 6.16 & 5.80 & 2.38 & 0.43 \\
\hline $\mathrm{CaO}$ & 4.37 & 1.40 & 2.28 & 3.00 & 2.87 & 5.18 & 8.04 & 7.95 & 4.46 & 0.71 \\
\hline $\mathrm{Na}_{2} \mathrm{O}$ & 2.69 & 2.50 & 2.88 & 2.80 & 3.00 & 2.43 & 1.87 & 1.88 & 2.52 & 3.80 \\
\hline $\mathrm{K}_{2} \mathrm{O}$ & 2.78 & 5.23 & 4.05 & 3.74 & 3.19 & 2.26 & 1.61 & 1.85 & 2.69 & 4.15 \\
\hline $\mathrm{P}_{2} \mathrm{O}_{5}$ & 0.26 & 0.20 & 0.16 & 0.16 & 0.17 & 0.11 & 0.12 & 0.11 & 0.11 & 0.07 \\
\hline LOI & 1.30 & 0.83 & 1.12 & 1.07 & 0.85 & 2.12 & 1.97 & 1.88 & 1.54 & 1.03 \\
\hline Total & 98.18 & 97.92 & 97.99 & 98.96 & 97.81 & 99.41 & 98.42 & 98.64 & 97.49 & 98.73 \\
\hline$F(w t \%)$ & 0.09 & 0.08 & 0.09 & 0.09 & 0.09 & 0.03 & 0.04 & 0.03 & 0.05 & 0.01 \\
\hline ASI & 1.06 & 1.11 & 1.1 & 1.11 & 1.09 & 0.98 & 0.71 & 0.72 & 0.96 & 1.10 \\
\hline CIA (\%) & 51.4 & 52.7 & 52.3 & 52.6 & 52.1 & 49.5 & 41.7 & 41.7 & 49.0 & 52.3 \\
\hline $\mathrm{Rb}$ (ppm) & 150 & 267 & 211 & 163 & 155 & 90 & 69 & 73 & 118 & 159 \\
\hline $\mathrm{Sr}$ & 326 & 136 & 202 & 333 & 284 & 332 & 383 & 405 & 213 & 160 \\
\hline Cs & 5.1 & 7.2 & 7.8 & 7.0 & 7.1 & 3.5 & 4.1 & 4.5 & 5.3 & 2.8 \\
\hline $\mathrm{Ba}$ & 787 & 605 & 667 & 1210 & 695 & 667 & 569 & 707 & 585 & 721 \\
\hline $\mathrm{Sn}$ & 2 & 5 & 5 & 5 & 3 & 2 & 3 & 2 & 4 & 3 \\
\hline $\mathrm{Zr}$ & 253 & 149 & 151 & 209 & 175 & 97 & 80 & 91 & 128 & 175 \\
\hline Hf & 6.7 & 4.7 & 4.5 & 6.3 & 5.4 & 3.0 & 2.5 & 2.7 & 4.0 & 5.0 \\
\hline $\mathrm{Nb}$ & 14.5 & 12.2 & 11.4 & 12.6 & 12.1 & 5.7 & 4.4 & 4.1 & 7.0 & 11.6 \\
\hline $\mathrm{Ta}$ & 1. & 1.7 & 1.55 & 1.03 & 1.19 & 0.73 & 0.49 & 0.42 & 0.96 & 1.62 \\
\hline V & 106 & 26 & 42 & 60 & 58 & 112 & 226 & 200 & 106 & 13 \\
\hline Co & 68 & 63 & 75 & 83 & 62 & 48 & 60 & 60 & 74 & 62 \\
\hline $\mathrm{Zn}$ & 90 & 60 & 60 & 70 & 60 & 70 & 90 & 60 & 70 & 40 \\
\hline $\mathrm{Ga}$ & 23 & 22 & 19 & 20 & 20 & 16 & 16 & 15 & 16 & 16 \\
\hline $\mathrm{Ge}$ & 1 & 2 & 2 & 2 & 2 & 2 & 2 & 2 & 2 & 1 \\
\hline $\mathrm{Pb}$ & 16 & 42 & 33 & 29 & 23 & 15 & 15 & 12 & 27 & 22 \\
\hline Th & 13.3 & 17.9 & 16.5 & 23.2 & 18.0 & 14.6 & 7.86 & 7.35 & 22.3 & 22.0 \\
\hline $\mathrm{U}$ & 1.54 & 6.84 & 6.98 & 4.10 & 3.26 & 1.95 & 1.72 & 1.45 & 3.69 & 4.07 \\
\hline $\mathrm{Y}$ & 14.7 & 21.5 & 25.3 & 34.8 & 33.3 & 18.9 & 20.2 & 17.1 & 25.1 & 19.9 \\
\hline $\mathrm{La}$ & 46.2 & 37.4 & 38.8 & 59.2 & 45.3 & 29.5 & 20.0 & 17.7 & 41.4 & 37.7 \\
\hline $\mathrm{Ce}$ & 88.8 & 77.9 & 77.2 & 118 & 91.2 & 52.8 & 39.2 & 35.0 & 73.9 & 63.2 \\
\hline $\operatorname{Pr}$ & 10.4 & 9.35 & 9.26 & 14.6 & 11.2 & 5.77 & 4.85 & 4.29 & 8.10 & 6.89 \\
\hline $\mathrm{Nd}$ & 32.4 & 29.3 & 28.1 & 45.1 & 34.6 & 17.4 & 16.5 & 14.4 & 22.8 & 18.9 \\
\hline $\mathrm{Sm}$ & 5.60 & 6.09 & 5.76 & 8.80 & 7.11 & 3.15 & 3.30 & 2.94 & 4.19 & 3.32 \\
\hline $\mathrm{Eu}$ & 1.69 & 1.13 & 1.10 & 1.89 & 1.54 & 0.899 & 0.861 & 0.864 & 1.03 & 0.595 \\
\hline $\mathrm{Gd}$ & 4.69 & 5.04 & 5.08 & 7.67 & 6.36 & 2.86 & 3.30 & 2.99 & 3.95 & 3.04 \\
\hline $\mathrm{Tb}$ & 0.63 & 0.82 & 0.83 & 1.22 & 1.07 & 0.49 & 0.59 & 0.52 & 0.71 & 0.55 \\
\hline Dy & 3.03 & 3.92 & 4.24 & 6.11 & 5.65 & 2.98 & 3.25 & 2.91 & 3.97 & 3.05 \\
\hline Ho & 0.53 & 0.67 & 0.79 & 1.11 & 1.07 & 0.62 & 0.65 & 0.58 & 0.79 & 0.62 \\
\hline Er & 1.43 & 1.86 & 2.27 & 3.28 & 3.20 & 1.86 & 1.98 & 1.73 & 2.43 & 1.92 \\
\hline $\mathrm{Tm}$ & 0.193 & 0.276 & 0.335 & 0.472 & 0.468 & 0.292 & 0.292 & 0.263 & 0.373 & 0.302 \\
\hline $\mathrm{Yb}$ & 1.18 & 1.69 & 2.06 & 2.77 & 2.85 & 1.88 & 1.84 & 1.65 & 2.38 & 2.05 \\
\hline $\mathrm{Lu}$ & 0.172 & 0.241 & 0.297 & 0.401 & 0.421 & 0.290 & 0.289 & 0.249 & 0.362 & 0.317 \\
\hline$\Sigma$ LREE & 185.1 & 161.2 & 160.2 & 247.6 & 191.0 & 109.5 & 84.7 & 75.2 & 151.4 & 130.6 \\
\hline$\Sigma$ HREE & 11.9 & 14.5 & 15.9 & 23.0 & 21.1 & 11.3 & 12.2 & 10.9 & 15.0 & 11.8 \\
\hline$\Sigma \mathrm{REE}$ & 196.9 & 175.7 & 176.1 & 270.6 & 212.0 & 120.8 & 96.9 & 86.1 & 166.4 & 142.5 \\
\hline$\Sigma \mathrm{REE}+\mathrm{Y}$ & 211.6 & 197.2 & 201.4 & 305.4 & 245.3 & 139.7 & 117.1 & 103.2 & 191.5 & 162.4 \\
\hline LREE/HREE & 15.6 & 11.1 & 10.1 & 10.7 & 9.1 & 9.7 & 6.9 & 6.9 & 10.1 & 11.0 \\
\hline HREE/REE & 0.06 & 0.08 & 0.09 & 0.09 & 0.10 & 0.09 & 0.13 & 0.13 & 0.09 & 0.08 \\
\hline $\mathrm{Ce} / \mathrm{Ce}^{*}$ & 0.99 & 1.02 & 1.00 & 0.98 & 0.99 & 0.99 & 0.98 & 0.98 & 0.99 & 0.96 \\
\hline $\mathrm{Eu} / \mathrm{Eu} *$ & 1.01 & 0.62 & 0.62 & 0.70 & 0.70 & 0.92 & 0.80 & 0.89 & 0.77 & 0.57 \\
\hline $\mathrm{La}_{\mathrm{N}} / \mathrm{Yb}_{\mathrm{N}}$ & 28.1 & 15.9 & 13.5 & 15.3 & 11.4 & 11.3 & 7.8 & 7.7 & 12.5 & 13.2 \\
\hline $\mathrm{Rb} / \mathrm{Sr}$ & 0.46 & 1.96 & 1.04 & 0.49 & 0.55 & 0.27 & 0.18 & 0.18 & 0.55 & 0.99 \\
\hline
\end{tabular}


Appendix 1 Continued.

\begin{tabular}{|c|c|c|c|c|c|c|c|c|c|c|}
\hline Sequential \# & 31 & 32 & 33 & 34 & 35 & 36 & 37 & 38 & 39 & 40 \\
\hline Sample \# & $\mathrm{P} 716 \mathrm{~B}$ & $\mathrm{P} 724 \mathrm{C}$ & $\mathrm{P} 725 \mathrm{~A}$ & $\mathrm{P} 726 \mathrm{~B}$ & $\mathrm{P} 781 \mathrm{C}$ & P782B & $\mathrm{P} 783 \mathrm{~B}$ & $\mathrm{P} 783 \mathrm{C}$ & $\mathrm{P} 785 \mathrm{~B}$ & $\mathrm{P} 785 \mathrm{C}$ \\
\hline District & Attapu & Attapu & Attapu & Attapu & Attapu & Attapu & Attapu & Attapu & Attapu & Attapu \\
\hline Rock type & W Gr & W Gr & W Gr & W Gr & W Gr & W Gr & W Gr & W Gr & W Gr & W Gr \\
\hline Latitude & $14^{\circ} 47.937^{\prime}$ & $14^{\circ} 48.435^{\prime}$ & $14^{\circ} 49.306^{\prime}$ & $14^{\circ} 49.794^{\prime}$ & $14^{\circ} 46.998^{\prime}$ & $14^{\circ} 47.02^{\prime}$ & $14^{\circ} 47.075^{\prime}$ & $14^{\circ} 47.075^{\prime}$ & $14^{\circ} 47.086^{\prime}$ & $14^{\circ} 47.086^{\prime}$ \\
\hline Longitude & $107^{\circ} 29.399^{\prime}$ & $107^{\circ} 22.981^{\prime}$ & $107^{\circ} 22.1^{\prime}$ & $107^{\circ} 21.394^{\prime}$ & $107^{\circ} 30.531^{\prime}$ & $107^{\circ} 30.531^{\prime}$ & $107^{\circ} 30.476^{\prime}$ & $107^{\circ} 30.476^{\prime}$ & $107^{\circ} 30.321^{\prime}$ & $107^{\circ} 30.321^{\prime}$ \\
\hline $\mathrm{SiO}_{2}(\mathrm{wt} \%)$ & 49.79 & 71.84 & 64.19 & 66.09 & 71.76 & 65.53 & 69.49 & 71.34 & 66.29 & 68.40 \\
\hline $\mathrm{TiO}_{2}$ & 0.66 & 0.34 & 0.61 & 0.58 & 0.25 & 0.41 & 0.30 & 0.24 & 0.31 & 0.22 \\
\hline $\mathrm{Al}_{2} \mathrm{O}_{3}$ & 26.67 & 14.07 & 17.77 & 16.99 & 15.36 & 20.26 & 17.06 & 15.08 & 17.19 & 18.57 \\
\hline $\mathrm{Fe}_{2} \mathrm{O}_{3}$ * & 6.89 & 2.60 & 4.65 & 3.97 & 1.95 & 2.92 & 2.25 & 2.11 & 3.51 & 1.31 \\
\hline $\mathrm{MnO}$ & 0.018 & 0.040 & 0.012 & 0.049 & 0.027 & 0.021 & 0.014 & 0.016 & 0.032 & 0.006 \\
\hline $\mathrm{MgO}$ & 0.56 & 0.58 & 0.14 & 0.64 & 0.67 & 0.81 & 0.53 & 0.42 & 0.52 & 0.28 \\
\hline $\mathrm{CaO}$ & 0.05 & 0.76 & $<0.01$ & 0.09 & 2.20 & 0.13 & 0.29 & 0.86 & 1.22 & 0.16 \\
\hline $\mathrm{Na}_{2} \mathrm{O}$ & 0.13 & 1.47 & 0.02 & 0.24 & 3.93 & 0.25 & 0.52 & 1.81 & 1.94 & 0.75 \\
\hline $\mathrm{K}_{2} \mathrm{O}$ & 4.64 & 4.59 & 0.50 & 6.08 & 1.92 & 2.05 & 4.00 & 3.80 & 1.25 & 4.47 \\
\hline $\mathrm{P}_{2} \mathrm{O}_{5}$ & 0.06 & 0.05 & 0.07 & 0.06 & 0.02 & 0.02 & 0.02 & $<0.01$ & 0.05 & 0.02 \\
\hline LOI & 10.43 & 3.29 & 12.22 & 5.16 & 1.88 & 7.86 & 5.45 & 4.42 & 7.97 & 5.85 \\
\hline Total & 99.90 & 99.63 & 100.18 & 99.95 & 99.97 & 100.26 & 99.93 & 100.10 & 100.28 & 100.04 \\
\hline$F(w t \%)$ & 0.04 & n.a. & 0.02 & 0.06 & 0.03 & 0.03 & 0.02 & 0.02 & $<0.01$ & 0.02 \\
\hline CIA $(\%)$ & 83.4 & 61.6 & 96.8 & 70.4 & 55. & 87.6 & 74.9 & 63.5 & 71.8 & 74.5 \\
\hline $\mathrm{Rb}(\mathrm{ppm})$ & 191 & 179 & 53 & 241 & 67 & 79 & 103 & 101 & 64 & 142 \\
\hline $\mathrm{Sr}$ & 147 & 107 & 22 & 115 & 504 & 71 & 297 & 449 & 250 & 232 \\
\hline Cs & 3.1 & 5.8 & 2.4 & 6.5 & 1.2 & 2.3 & 1.4 & 1.3 & 1.9 & 1.9 \\
\hline $\mathrm{Ba}$ & 1200 & 716 & 148 & 1550 & 396 & 382 & 1890 & 1770 & 324 & 1120 \\
\hline $\mathrm{Sn}$ & 3 & 2 & 3 & 3 & 1 & 3 & $<1$ & 8 & 3 & 3 \\
\hline $\mathrm{Zr}$ & 484 & 235 & 309 & 333 & 124 & 212 & 166 & 156 & 257 & 180 \\
\hline Hf & 11.5 & 6.6 & 8.4 & 8.8 & 3.4 & 5.6 & 4.2 & 4.0 & 6.7 & 4.7 \\
\hline $\mathrm{Nb}$ & 19.7 & 8.0 & 13.1 & 11.7 & 7.0 & 12.4 & 8.3 & 6.0 & 11.9 & 7.9 \\
\hline $\mathrm{Ta}$ & 1.14 & 0.5 & 1.04 & 1.12 & 0.5 & 0.85 & 0.47 & 0.4 & 0.85 & 0.67 \\
\hline V & 69 & 28 & 77 & 66 & 26 & 34 & 27 & 20 & 38 & 27 \\
\hline Co & 6 & 5 & 5 & 8 & 3 & 7 & 4 & 3 & 9 & 4 \\
\hline $\mathrm{Zn}$ & 40 & $<30$ & $<30$ & 40 & $<30$ & 40 & 30 & $<30$ & 40 & $<30$ \\
\hline $\mathrm{Ga}$ & 35 & 14 & 21 & 19 & 20 & 26 & 21 & 18 & 23 & 23 \\
\hline $\mathrm{Ge}$ & 2 & 1 & 2 & 2 & 1 & 1 & 1 & 1 & 1 & 2 \\
\hline $\mathrm{Pb}$ & 33 & 23 & 59 & 42 & 14 & 45 & 50 & 20 & 30 & 34 \\
\hline Th & 37.6 & 54.6 & 94.7 & 47.6 & 45.3 & 32.7 & 22.0 & 28.2 & 14.5 & 13.2 \\
\hline $\mathrm{U}$ & 4.97 & 9.2 & 10.6 & 8.07 & 2.15 & 5.31 & 2.33 & 3.15 & 5.10 & 2.92 \\
\hline $\mathrm{Y}$ & 71 & 8.0 & 9.5 & 27.6 & 6.0 & 6.2 & 15.3 & 5.5 & 16.2 & 16.0 \\
\hline $\mathrm{La}$ & 172 & 57.7 & 152 & 88.1 & 59.7 & 39.8 & 94.1 & 30.8 & 60.8 & 76.0 \\
\hline $\mathrm{Ce}$ & 249 & 102 & 311 & 156 & 105 & 90.8 & 140 & 41.4 & 82.8 & 112 \\
\hline $\operatorname{Pr}$ & 33.7 & 10.6 & 23.5 & 17.5 & 9.32 & 6.68 & 15.4 & 4.82 & 11.0 & 13.4 \\
\hline $\mathrm{Nd}$ & 112.0 & 29.7 & 62.6 & 60.2 & 30.0 & 20.0 & 46.9 & 15.0 & 36.9 & 42.8 \\
\hline $\mathrm{Sm}$ & 19.3 & 5.10 & 7.88 & 8.93 & 3.74 & 2.81 & 6.32 & 1.98 & 5.76 & 6.08 \\
\hline $\mathrm{Eu}$ & 4.39 & 1.08 & 1.32 & 1.93 & 0.911 & 0.836 & 2.14 & 1.21 & 1.38 & 1.59 \\
\hline $\mathrm{Gd}$ & 15.7 & 3.8 & 3.50 & 6.88 & 1.84 & 1.20 & 4.04 & 1.46 & 4.22 & 4.30 \\
\hline $\mathrm{Tb}$ & 2.58 & 0.4 & 0.52 & 0.98 & 0.25 & 0.20 & 0.56 & 0.20 & 0.59 & 0.59 \\
\hline Dy & 13.4 & 2.0 & 2.58 & 5.14 & 1.23 & 1.18 & 2.85 & 0.97 & 2.94 & 2.80 \\
\hline Ho & 2.42 & 0.3 & 0.44 & 0.95 & 0.22 & 0.23 & 0.53 & 0.19 & 0.54 & 0.50 \\
\hline $\mathrm{Er}$ & 6.48 & 0.9 & 1.16 & 2.72 & 0.60 & 0.67 & 1.43 & 0.54 & 1.51 & 1.35 \\
\hline $\mathrm{Tm}$ & 0.844 & 0.14 & 0.149 & 0.391 & 0.087 & 0.10 & 0.206 & 0.088 & 0.21 & 0.178 \\
\hline $\mathrm{Yb}$ & 4.95 & 0.9 & 0.93 & 2.46 & 0.58 & 0.69 & 1.33 & 0.64 & 1.31 & 1.12 \\
\hline $\mathrm{Lu}$ & 0.706 & 0.14 & 0.150 & 0.376 & 0.092 & 0.113 & 0.205 & 0.109 & 0.204 & 0.165 \\
\hline$\Sigma$ LREE & 590.4 & 206.2 & 558.3 & 332.7 & 208.7 & 160.9 & 304.9 & 95.2 & 198.6 & 251.9 \\
\hline$\Sigma$ HREE & 47.1 & 8.6 & 9.4 & 19.9 & 4.9 & 4.4 & 11.2 & 4.2 & 11.5 & 11.0 \\
\hline$\Sigma \mathrm{REE}$ & 637.5 & 214.8 & 567.7 & 352.6 & 213.6 & 165.3 & 316.0 & 99.4 & 210.2 & 262.9 \\
\hline$\Sigma \mathrm{REE}+\mathrm{Y}$ & 708.5 & 222.8 & 577.2 & 380.2 & 219.6 & 171.5 & 331.3 & 104.9 & 226.4 & 278.9 \\
\hline LREE/HREE & 12.5 & 24.0 & 59.2 & 16.7 & 42.6 & 36.7 & 27.3 & 22.7 & 17.2 & 22.9 \\
\hline HREE/REE & 0.07 & 0.04 & 0.02 & 0.06 & 0.02 & 0.03 & 0.04 & 0.04 & 0.05 & 0.04 \\
\hline $\mathrm{Ce} / \mathrm{Ce} *$ & 0.80 & 1.01 & 1.28 & 0.97 & 1.09 & 1.37 & 0.90 & 0.83 & 0.78 & 0.86 \\
\hline $\mathrm{Eu} / \mathrm{Eu}^{*}$ & 0.77 & 0.75 & 0.77 & 0.75 & 1.06 & 1.39 & 1.29 & 2.18 & 0.86 & 0.95 \\
\hline $\mathrm{La}_{N} / \mathrm{Yb}_{\mathrm{N}}$ & 24.9 & 46.0 & 117.2 & 25.7 & 73.8 & 41.4 & 50.8 & 34.5 & 33.3 & 48.7 \\
\hline
\end{tabular}


Appendix 1 Continued.

\begin{tabular}{|c|c|c|c|c|c|c|c|c|c|c|}
\hline Sequential \# & 41 & 42 & 43 & 44 & 45 & 46 & 47 & 48 & 49 & 50 \\
\hline Sample \# & $\mathrm{P} 786 \mathrm{C}$ & P790C & P791B1 & P791B2 & $62803 \mathrm{~B}$ & $62805 \mathrm{~B}$ & $62807 \mathrm{~B}$ & $62808 \mathrm{~A}$ & $62810 \mathrm{~B}$ & $63003 \mathrm{~A}$ \\
\hline District & Attapu & Attapu & Attapu & Attapu & Boneng & Boneng & Boneng & Boneng & Boneng & Nape \\
\hline Rock type & W Gr & W Gr & W Gr & W Gr & W Gr & W Gr & W Gr & W Gr & W Gr & W Gr \\
\hline Latitude & $14^{\circ} 47.111^{\prime}$ & $14^{\circ} 48.069^{\prime}$ & $14^{\circ} 49.017^{\prime}$ & $14^{\circ} 49.017^{\prime}$ & $17^{\circ} 58.755^{\prime}$ & $17^{\circ} 58.730^{\prime}$ & $17^{\circ} 58.730^{\prime}$ & $17^{\circ} 58.854^{\prime}$ & $17^{\circ} 58.692^{\prime}$ & $18^{\circ} 9.492^{\prime}$ \\
\hline Longitude & $107^{\circ} 30.247^{\prime}$ & $102^{\circ} 28.691^{\prime}$ & $107^{\circ} 28.032^{\prime}$ & $107^{\circ} 28.032^{\prime}$ & $104^{\circ} 18.507^{\prime}$ & $104^{\circ} 18.5^{\prime}$ & $104^{\circ} 18.5^{\prime}$ & $104^{\circ} 18.468^{\prime}$ & $104^{\circ} 18.621^{\prime}$ & $105^{\circ} 12.102^{\prime}$ \\
\hline $\mathrm{SiO}_{2}(\mathrm{wt} \%)$ & 66.20 & 73.42 & 65.53 & 53.02 & 63.10 & 62.75 & 65.65 & 72.40 & 67.01 & 77.22 \\
\hline $\mathrm{TiO}_{2}$ & 0.47 & 0.04 & 0.48 & 0.96 & 0.37 & 0.35 & 0.37 & 0.27 & 0.38 & 0.24 \\
\hline $\mathrm{Al}_{2} \mathrm{O}_{3}$ & 18.20 & 16.05 & 18.79 & 21.81 & 18.79 & 19.29 & 16.29 & 13.49 & 15.03 & 9.28 \\
\hline $\mathrm{Fe}_{2} \mathrm{O}_{3}$ * & 3.63 & 0.65 & 3.64 & 7.82 & 3.44 & 3.72 & 3.54 & 2.42 & 5.48 & 1.69 \\
\hline $\mathrm{MnO}$ & 0.056 & 0.004 & 0.045 & 0.027 & 0.014 & 0.009 & 0.016 & 0.010 & 0.028 & 0.010 \\
\hline $\mathrm{MgO}$ & 1.12 & 0.32 & 0.63 & 0.77 & 0.38 & 0.26 & 0.31 & 0.20 & 0.50 & 0.27 \\
\hline $\mathrm{CaO}$ & 1.60 & $<0.01$ & 0.02 & $<0.01$ & 0.01 & 0.02 & 0.02 & 0.02 & 0.01 & 0.05 \\
\hline $\mathrm{Na}_{2} \mathrm{O}$ & 2.66 & 0.13 & 0.17 & 0.06 & 0.04 & 0.07 & 0.13 & 0.14 & 0.05 & 0.28 \\
\hline $\mathrm{K}_{2} \mathrm{O}$ & 1.42 & 5.23 & 5.33 & 2.84 & 3.04 & 1.98 & 3.13 & 2.02 & 2.42 & 2.75 \\
\hline $\mathrm{P}_{2} \mathrm{O}_{5}$ & 0.02 & 0.04 & 0.05 & 0.09 & 0.04 & 0.04 & 0.04 & 0.03 & 0.06 & 0.07 \\
\hline LOI & 4.86 & 4.29 & 5.43 & 12.72 & 8.71 & 10.33 & 7.66 & 7.07 & 7.01 & 5.94 \\
\hline Total & 100.23 & 100.17 & 100.12 & 100.12 & 97.93 & 98.80 & 97.12 & 98.04 & 97.95 & 97.79 \\
\hline$F(w t \%)$ & 0.06 & 0.04 & 0.06 & 0.09 & n.a. & n.a. & n.a. & n.a. & n.a. & n.a. \\
\hline CIA (\%) & 67.4 & 73.2 & 75.5 & 87.3 & 84.8 & 89.4 & 81.7 & 84.6 & 84.7 & 72.5 \\
\hline $\mathrm{Rb}$ (ppm) & 90 & 190 & 266 & 236 & 134 & 103 & 122 & 98 & 97 & 191 \\
\hline $\mathrm{Sr}$ & 306 & 155 & 133 & 48 & 9 & 8 & 17 & 10 & 8 & 23 \\
\hline Cs & 1.5 & 2.8 & 6.1 & 6.6 & 3.6 & 3.0 & 2.8 & 4.0 & 4.0 & 30.8 \\
\hline $\mathrm{Ba}$ & 328 & 1320 & 928 & 505 & 611 & 402 & 717 & 415 & 435 & 219 \\
\hline $\mathrm{Sn}$ & 3 & 7 & 3 & 7 & 5 & 5 & 5 & 3 & 3 & 8 \\
\hline $\mathrm{Zr}$ & 268 & 27 & 188 & 355 & 294 & 280 & 301 & 262 & 314 & 129 \\
\hline $\mathrm{Hf}$ & 6.1 & 1.0 & 5.0 & 8.5 & 9.0 & 8.8 & 9.2 & 7.8 & 9.2 & 4.0 \\
\hline $\mathrm{Nb}$ & 15.4 & 1.5 & 22.2 & 31.1 & 19.9 & 18. & 17.8 & 14.7 & 16.9 & 9.2 \\
\hline $\mathrm{Ta}$ & 0.65 & 0.97 & 2.48 & 2.35 & 2.08 & 1.92 & 1.73 & 1.39 & 1.56 & 1.56 \\
\hline $\mathrm{V}$ & 37 & 15 & 66 & 169 & 22 & 22 & 20 & 14 & 23 & 23 \\
\hline Co & 7 & 2 & 16 & 11 & 40 & 54 & 54 & 55 & 45 & 80 \\
\hline $\mathrm{Zn}$ & 60 & $<30$ & 40 & 60 & 70 & 50 & 60 & 40 & 100 & $<30$ \\
\hline $\mathrm{Ga}$ & 24 & 16 & 24 & 30 & 25 & 28 & 26 & 18 & 24 & 14 \\
\hline $\mathrm{Ge}$ & 1 & 2 & 2 & 2 & 2 & 1 & 2 & 1 & 2 & 4 \\
\hline $\mathrm{Pb}$ & 11 & 18 & 18 & 98 & 59 & 38 & 60 & 33 & 54 & 15 \\
\hline Th & 13.1 & 4.94 & 32.1 & 69.2 & 28.4 & 32.9 & 27.3 & 18.8 & 21.1 & 9.65 \\
\hline $\mathrm{U}$ & 6.0 & 1.66 & 3.68 & 12.3 & 3.59 & 3.66 & 4.00 & 2.63 & 5.83 & 4.51 \\
\hline $\mathrm{Y}$ & 9.2 & 20.0 & 25.4 & 58.3 & 43.5 & 38.4 & 37.8 & 28.2 & 59.2 & 13.6 \\
\hline $\mathrm{La}$ & 35.1 & 40.7 & 152 & 209 & 70.7 & 77.3 & 85.2 & 50.3 & 59.5 & 20.4 \\
\hline $\mathrm{Ce}$ & 66.1 & 51.0 & 248 & 388 & 86.1 & 89.7 & 97.7 & 138 & 327 & 41.1 \\
\hline $\operatorname{Pr}$ & 6.48 & 8.84 & 25.6 & 38.0 & 13.6 & 15.5 & 16.1 & 11.9 & 12.6 & 4.98 \\
\hline $\mathrm{Nd}$ & 20.4 & 33.5 & 78.4 & 123.0 & 37.9 & 44.7 & 46.0 & 35.0 & 37.9 & 16.2 \\
\hline $\mathrm{Sm}$ & 3.16 & 6.20 & 9.93 & 18.3 & 6.39 & 7.56 & 7.89 & 6.39 & 7.45 & 3.29 \\
\hline $\mathrm{Eu}$ & 0.872 & 1.84 & 1.95 & 3.41 & 0.904 & 1.05 & 1.12 & 1.00 & 1.32 & 0.47 \\
\hline $\mathrm{Gd}$ & 2.01 & 5.36 & 5.43 & 11.4 & 6.23 & 7.10 & 7.26 & 5.55 & 8.91 & 3.18 \\
\hline $\mathrm{Tb}$ & 0.33 & 0.80 & 0.79 & 1.86 & 1.04 & 1.09 & 1.14 & 0.88 & 1.50 & 0.51 \\
\hline Dy & 1.83 & 4.06 & 4.25 & 10.1 & 6.31 & 6.15 & 6.31 & 4.91 & 8.68 & 2.61 \\
\hline Ho & 0.33 & 0.68 & 0.81 & 1.93 & 1.36 & 1.24 & 1.26 & 0.97 & 1.82 & 0.45 \\
\hline $\mathrm{Er}$ & 0.95 & 1.76 & 2.35 & 5.65 & 4.46 & 3.99 & 3.96 & 3.10 & 5.77 & 1.25 \\
\hline $\mathrm{Tm}$ & 0.133 & 0.226 & 0.350 & 0.829 & 0.705 & 0.638 & 0.622 & 0.503 & 0.914 & 0.186 \\
\hline $\mathrm{Yb}$ & 0.87 & 1.34 & 2.24 & 5.17 & 4.51 & 4.08 & 3.98 & 3.23 & 5.80 & 1.17 \\
\hline $\mathrm{Lu}$ & 0.142 & 0.180 & 0.342 & 0.778 & 0.678 & 0.625 & 0.605 & 0.477 & 0.869 & 0.171 \\
\hline$\Sigma$ LREE & 132.1 & 142.1 & 515.9 & 779.7 & 215.6 & 235.8 & 254.0 & 242.6 & 445.8 & 86.4 \\
\hline$\Sigma$ HREE & 6.6 & 14.4 & 16.6 & 37.7 & 25.3 & 24.9 & 25.1 & 19.6 & 34.3 & 9.5 \\
\hline$\Sigma$ REE & 138.7 & 156.5 & 532.4 & 817.4 & 240.9 & 260.7 & 279.1 & 262.2 & 480.0 & 96.0 \\
\hline$\Sigma \mathrm{REE}+\mathrm{Y}$ & 147.9 & 176.5 & 557.8 & 875.7 & 284.4 & 299.1 & 316.9 & 290.4 & 539.2 & 109.6 \\
\hline LREE/HREE & 20.0 & 9.9 & 31.1 & 20.7 & 8.5 & 9.5 & 10.1 & 12.4 & 13.0 & 9.1 \\
\hline HREE/REE & 0.05 & 0.09 & 0.03 & 0.05 & 0.10 & 0.10 & 0.09 & 0.07 & 0.07 & 0.10 \\
\hline $\mathrm{Ce} / \mathrm{Ce}^{*}$ & 1.07 & 0.66 & 0.97 & 1.07 & 0.68 & 0.64 & 0.65 & 1.38 & 2.93 & 1.00 \\
\hline $\mathrm{Eu} / \mathrm{Eu}^{*}$ & 1.06 & 0.98 & 0.81 & 0.72 & 0.44 & 0.44 & 0.45 & 0.51 & 0.50 & 0.44 \\
\hline $\mathrm{La}_{N} / \mathrm{Yb}_{\mathrm{N}}$ & 28.9 & 21.8 & 48.7 & 29.0 & 11.2 & 13.6 & 15.4 & 11.2 & 7.4 & 12.5 \\
\hline
\end{tabular}


Appendix 1 Continued.

\begin{tabular}{|c|c|c|c|c|c|c|c|c|c|c|}
\hline $\begin{array}{l}\text { Sequential \# } \\
\text { Sample \# }\end{array}$ & $\begin{array}{c}51 \\
63004 \mathrm{~B} \\
\end{array}$ & $\begin{array}{c}52 \\
63005 \mathrm{~B} \\
\end{array}$ & $\begin{array}{c}53 \\
63005 \mathrm{C} \\
\end{array}$ & $\begin{array}{c}54 \\
70101 \mathrm{~B} \\
\end{array}$ & $\begin{array}{c}55 \\
70101 \mathrm{C} \\
\end{array}$ & $\begin{array}{c}56 \\
70102 \mathrm{~B} \\
\end{array}$ & $\begin{array}{c}57 \\
70102 \mathrm{C} \\
\end{array}$ & $\begin{array}{c}58 \\
70103 \mathrm{~B} \\
\end{array}$ & $\begin{array}{c}59 \\
70104 \mathrm{~B} 1 \\
\end{array}$ & $\begin{array}{c}60 \\
70104 \mathrm{~B} 2 \\
\end{array}$ \\
\hline District & Nape & Nape & Nape & Nape & Nape & Nape & Nape & Nape & Nape & Nape \\
\hline Rock type & W Gr & W Gr & W Gr & W Gr & W Gr & W Gr & W Gr & W Gr & W Gr & W Gr \\
\hline Latitude & $18^{\circ} 9.587^{\prime}$ & $18^{\circ} 17.439^{\prime}$ & $18^{\circ} 17.431^{\prime}$ & $18^{\circ} 18.552^{\prime}$ & $18^{\circ} 18.552^{\prime}$ & $18^{\circ} 18.811^{\prime}$ & $18^{\circ} 18.811^{\prime}$ & $18^{\circ} 19.219^{\prime}$ & $18^{\circ} 19.524^{\prime}$ & $18^{\circ} 19.524^{\prime}$ \\
\hline Longitude & $105^{\circ} 11.961^{\prime}$ & $105^{\circ} 04.021^{\prime}$ & $105^{\circ} 04.013^{\prime}$ & $105^{\circ} 05.671^{\prime}$ & $105^{\circ} 05.671^{\prime}$ & $105^{\circ} 06.107^{\prime}$ & $105^{\circ} 06.107^{\prime}$ & $105^{\circ} 06.435^{\prime}$ & $105^{\circ} 06.586^{\prime}$ & $105^{\circ} 06.586^{\prime}$ \\
\hline $\mathrm{SiO}_{2}(\mathrm{wt} \%)$ & 71.44 & 72.61 & 71.04 & 64.42 & 68.70 & 71.32 & 67.19 & 66.70 & 53.90 & 65.95 \\
\hline $\mathrm{TiO}_{2}$ & 0.31 & 0.21 & 0.21 & 0.43 & 0.41 & 0.32 & 0.49 & 0.30 & 0.43 & 0.34 \\
\hline $\mathrm{Al}_{2} \mathrm{O}_{3}$ & 13.38 & 14.67 & 14.18 & 18.33 & 14.76 & 12.76 & 14.06 & 17.49 & 22.96 & 17.53 \\
\hline $\mathrm{Fe}_{2} \mathrm{O}_{3}$ * & 2.07 & 2.06 & 2.14 & 3.73 & 3.55 & 2.54 & 3.98 & 2.30 & 3.67 & 2.84 \\
\hline $\mathrm{MnO}$ & 0.018 & 0.065 & 0.058 & 0.039 & 0.051 & 0.04 & 0.05 & 0.04 & 0.017 & 0.03 \\
\hline $\mathrm{MgO}$ & 0.39 & 0.22 & 0.46 & 0.65 & 1.05 & 0.49 & 1.23 & 0.29 & 0.33 & 0.28 \\
\hline $\mathrm{CaO}$ & 0.10 & 0.03 & 0.69 & 0.02 & 0.41 & 0.04 & 0.34 & 0.03 & 0.04 & 0.07 \\
\hline $\mathrm{Na}_{2} \mathrm{O}$ & 0.64 & 0.14 & 2.46 & 0.18 & 0.76 & 0.20 & 3.27 & 0.13 & 0.10 & 0.09 \\
\hline $\mathrm{K}_{2} \mathrm{O}$ & 4.29 & 2.58 & 4.29 & 3.15 & 3.65 & 3.69 & 3.15 & 3.92 & 3.43 & 3.24 \\
\hline $\mathrm{P}_{2} \mathrm{O}_{5}$ & 0.10 & 0.06 & 0.07 & 0.05 & 0.07 & 0.06 & 0.08 & 0.06 & 0.06 & 0.05 \\
\hline LOI & 5.83 & 5.40 & 2.69 & 7.61 & 5.30 & 6.31 & 4.11 & 7.17 & 13.23 & 7.45 \\
\hline Total & 98.55 & 98.11 & 98.27 & 98.58 & 98.68 & 97.76 & 97.93 & 98.4 & 98.14 & 97.88 \\
\hline $\mathrm{F}(\mathrm{wt} \%)$ & n.a. & n.a. & n.a. & n.a. & n.a. & n.a. & n.a. & n.a. & n.a. & n.a. \\
\hline CIA (\%) & 69.5 & 82.7 & 58.8 & 83. & 71.3 & 74.4 & 59.9 & 79.5 & 85.3 & 82.3 \\
\hline $\mathrm{Rb}(\mathrm{ppm})$ & 255 & 171 & 200 & 166 & 187 & 233 & 153 & 254 & 189 & 211 \\
\hline $\mathrm{Sr}$ & 29 & 36 & 152 & 56 & 93 & 60 & 176 & 49 & 23 & 17 \\
\hline Cs & 15.5 & 5.5 & 6.7 & 7.0 & 6.6 & 8.2 & 3.6 & 13.7 & 6.3 & 6.5 \\
\hline $\mathrm{Ba}$ & 278 & 289 & 504 & 650 & 612 & 517 & 832 & 368 & 360 & 330 \\
\hline $\mathrm{Sn}$ & 9 & 5 & 5 & 12 & 6 & 15 & 6 & 13 & 8 & 6 \\
\hline $\mathrm{Zr}$ & 172 & 98 & 94 & 148 & 166 & 118 & 180 & 123 & 160 & 134 \\
\hline $\mathrm{Hf}$ & 5.4 & 3.6 & 3.2 & 4.6 & 5.4 & 3.7 & 5.4 & 4.3 & 5.3 & 4.6 \\
\hline $\mathrm{Nb}$ & 14.1 & 9.2 & 9.0 & 12.5 & 11.2 & 10.1 & 13.6 & 15.6 & 15.4 & 13.9 \\
\hline $\mathrm{Ta}$ & 2.3 & 1.6 & 1.39 & 1.71 & 1.21 & 1.53 & 1.62 & 3.19 & 2.31 & 1.97 \\
\hline V & 29 & 23 & 22 & 45 & 45 & 34 & 52 & 31 & 47 & 39 \\
\hline Co & 86 & 61 & 62 & 63 & 73 & 41 & 65 & 84 & 33 & 52 \\
\hline $\mathrm{Zn}$ & 40 & 40 & 40 & 50 & 50 & 50 & 50 & 30 & 30 & $<30$ \\
\hline $\mathrm{Ga}$ & 20 & 19 & 17 & 22 & 18 & 18 & 19 & 22 & 24 & 20 \\
\hline $\mathrm{Ge}$ & 2 & 2 & 2 & 2 & 2 & 2 & 1 & 2 & 2 & 2 \\
\hline $\mathrm{Pb}$ & 17 & 31 & 37 & 38 & 30 & 30 & 18 & 35 & 46 & 63 \\
\hline Th & 11.1 & 9.98 & 9.56 & 18.0 & 18.1 & 15.2 & 22.1 & 16.0 & 19.1 & 16.6 \\
\hline U & 5.70 & 8.76 & 3.18 & 7.44 & 6.31 & 5.31 & 6.59 & 17.7 & 10.4 & 9.02 \\
\hline $\mathrm{Y}$ & 16.5 & 129 & 25.6 & 37.7 & 33.6 & 19.6 & 27.7 & 22.5 & 34.9 & 22.2 \\
\hline $\mathrm{La}$ & 23.2 & 27.8 & 22.5 & 49.8 & 42.9 & 38.1 & 43.7 & 18.5 & 54.6 & 28.2 \\
\hline $\mathrm{Ce}$ & 41.7 & 35.2 & 46.8 & 85.8 & 84.9 & 74.5 & 88.8 & 44.3 & 79.9 & 52.2 \\
\hline $\operatorname{Pr}$ & 5.54 & 7.98 & 5.58 & 12.5 & 10.3 & 8.87 & 10.7 & 4.35 & 13.7 & 7.29 \\
\hline $\mathrm{Nd}$ & 19.0 & 30.3 & 18.4 & 38.6 & 32.2 & 27.3 & 33.2 & 13.5 & 42.8 & 22.9 \\
\hline $\mathrm{Sm}$ & 4.03 & 9.41 & 3.81 & 8.01 & 6.55 & 5.23 & 6.54 & 2.90 & 8.69 & 5.05 \\
\hline $\mathrm{Eu}$ & 0.575 & 3.70 & 0.935 & 1.71 & 1.11 & 1.05 & 1.14 & 0.829 & 2.28 & 1.31 \\
\hline $\mathrm{Gd}$ & 3.87 & 14.7 & 3.8 & 7.36 & 5.98 & 4.69 & 5.92 & 3.18 & 7.93 & 4.58 \\
\hline $\mathrm{Tb}$ & 0.61 & 2.79 & 0.71 & 1.18 & 1.01 & 0.74 & 0.96 & 0.58 & 1.21 & 0.77 \\
\hline Dy & 3.08 & 18.0 & 4.16 & 6.26 & 5.61 & 3.66 & 4.83 & 3.44 & 6.20 & 3.97 \\
\hline Ho & 0.55 & 3.45 & 0.81 & 1.18 & 1.10 & 0.65 & 0.89 & 0.69 & 1.09 & 0.74 \\
\hline Er & 1.52 & 9.81 & 2.44 & 3.65 & 3.45 & 1.84 & 2.52 & 2.18 & 3.25 & 2.20 \\
\hline $\mathrm{Tm}$ & 0.223 & 1.48 & 0.399 & 0.556 & 0.535 & 0.266 & 0.381 & 0.376 & 0.492 & 0.346 \\
\hline $\mathrm{Yb}$ & 1.40 & 8.91 & 2.56 & 3.50 & 3.36 & 1.61 & 2.27 & 2.50 & 3.16 & 2.30 \\
\hline $\mathrm{Lu}$ & 0.199 & 1.16 & 0.366 & 0.492 & 0.492 & 0.228 & 0.314 & 0.365 & 0.443 & 0.324 \\
\hline$\Sigma$ LREE & 94.0 & 114.4 & 98.0 & 196.4 & 178.0 & 155.1 & 184.1 & 84.4 & 202.0 & 117.0 \\
\hline$\Sigma$ HREE & 11.5 & 60.3 & 15.2 & 24.2 & 21.5 & 13.7 & 18.1 & 13.3 & 23.8 & 15.2 \\
\hline$\Sigma \mathrm{REE}$ & 105.5 & 174.7 & 113.3 & 220.6 & 199.5 & 168.7 & 202.2 & 97.7 & 225.7 & 132.2 \\
\hline$\Sigma \mathrm{REE}+\mathrm{Y}$ & 122.0 & 303.7 & 138.9 & 258.3 & 233.1 & 188.3 & 229.9 & 120.2 & 260.6 & 154.4 \\
\hline LREE/HREE & 8.2 & 1.9 & 6.4 & 8.1 & 8.3 & 11.3 & 10.2 & 6.3 & 8.5 & 7.7 \\
\hline HREE/REE & 0.11 & 0.35 & 0.13 & 0.11 & 0.11 & 0.08 & 0.09 & 0.14 & 0.11 & 0.12 \\
\hline $\mathrm{Ce} / \mathrm{Ce} *$ & 0.90 & 0.58 & 1.02 & 0.84 & 0.99 & 0.99 & 1.01 & 1.21 & 0.72 & 0.89 \\
\hline $\mathrm{Eu} / \mathrm{Eu}^{*}$ & 0.45 & 0.96 & 0.75 & 0.68 & 0.54 & 0.65 & 0.56 & 0.83 & 0.84 & 0.83 \\
\hline $\mathrm{La}_{\mathrm{N}} / \mathrm{Yb}_{\mathrm{N}}$ & 11.9 & 2.2 & 6.3 & 10.2 & 9.2 & 17.0 & 13.8 & 5.3 & 12.4 & 8.8 \\
\hline
\end{tabular}


Appendix 1 Continued.

\begin{tabular}{|c|c|c|c|c|c|c|c|c|c|c|}
\hline Sequential \# & 61 & 62 & 63 & 64 & 65 & 66 & 67 & 68 & 69 & 70 \\
\hline Sample \# & $70106 \mathrm{~B}$ & $70106 \mathrm{C}$ & 70107B & $70107 \mathrm{C}$ & 70108B & $70109 \mathrm{C}$ & $70111 \mathrm{~B}$ & $70112 \mathrm{~A}$ & $70112 \mathrm{~B} 1$ & $70112 \mathrm{~B} 2$ \\
\hline District & Nape & Nape & Nape & Nape & Nape & Nape & Nape & Nape & Nape & Nape \\
\hline Rock type & W Gr & W Gr & W Gr & W Gr & W Gr & W Gr & W Gr & W Gr & W Gr & W Gr \\
\hline Latitude & $18^{\circ} 19.845^{\prime}$ & $18^{\circ} 19.845^{\prime}$ & $18^{\circ} 20.932^{\prime}$ & $18^{\circ} 20.932^{\prime}$ & $18^{\circ} 21.499^{\prime}$ & $18^{\circ} 22.071^{\prime}$ & $18^{\circ} 19.027^{\prime}$ & $18^{\circ} 19.797^{\prime}$ & $18^{\circ} 19.797^{\prime}$ & $18^{\circ} 19.797^{\prime}$ \\
\hline Longitude & $105^{\circ} 06.848^{\prime}$ & $105^{\circ} 06.848^{\prime}$ & $105^{\circ} 07.79^{\prime}$ & $105^{\circ} 07.79^{\prime}$ & $105^{\circ} 8.026^{\prime}$ & $105^{\circ} 08.406^{\prime}$ & $105^{\circ} 02.474^{\prime}$ & $105^{\circ} 02.066^{\prime}$ & $105^{\circ} 02.066^{\prime}$ & $105^{\circ} 02.066^{\prime}$ \\
\hline $\mathrm{SiO}_{2}(\mathrm{wt} \%)$ & 56.19 & 72.30 & 68.63 & 67.50 & 70.07 & 62.93 & 74.93 & 68.85 & 74.45 & 65.03 \\
\hline $\mathrm{TiO}_{2}$ & 0.96 & 0.20 & 0.32 & 0.61 & 0.23 & 0.53 & 0.27 & 0.26 & 0.23 & 0.31 \\
\hline $\mathrm{Al}_{2} \mathrm{O}_{3}$ & 18.17 & 14.92 & 16.95 & 14.34 & 14.61 & 15.77 & 12.37 & 14.40 & 11.77 & 17.28 \\
\hline $\mathrm{Fe}_{2} \mathrm{O}_{3}$ * & 6.74 & 1.63 & 1.92 & 4.24 & 1.98 & 4.58 & 2.29 & 3.21 & 2.62 & 3.16 \\
\hline $\mathrm{MnO}$ & 0.075 & 0.022 & 0.013 & 0.042 & 0.018 & 0.063 & 0.007 & 0.021 & 0.014 & 0.022 \\
\hline $\mathrm{MgO}$ & 2.56 & 0.26 & 0.37 & 1.52 & 0.21 & 1.41 & 0.10 & 0.28 & 0.25 & 0.37 \\
\hline $\mathrm{CaO}$ & 0.15 & 0.03 & 0.02 & 0.15 & 0.02 & 0.65 & 0.02 & 0.04 & 0.04 & 0.04 \\
\hline $\mathrm{Na}_{2} \mathrm{O}$ & 0.09 & 0.18 & 0.09 & 0.49 & 0.14 & 0.83 & 0.03 & 0.12 & 0.10 & 0.22 \\
\hline $\mathrm{K}_{2} \mathrm{O}$ & 2.38 & 4.19 & 2.47 & 5.65 & 3.90 & 3.36 & 0.52 & 2.03 & 1.95 & 4.25 \\
\hline $\mathrm{P}_{2} \mathrm{O}_{5}$ & 0.16 & 0.05 & 0.04 & 0.10 & 0.07 & 0.07 & 0.02 & 0.04 & 0.04 & 0.04 \\
\hline LOI & 9.99 & 5.24 & 7.15 & 3.71 & 6.46 & 5.43 & 7.43 & 8.73 & 7.04 & 6.28 \\
\hline Total & 97.45 & 99.02 & 97.96 & 98.33 & 97.69 & 95.59 & 97.97 & 97.96 & 98.47 & 96.98 \\
\hline$F(w t \%)$ & n.a. & n.a. & n.a. & n.a. & n.a. & n.a. & n.a. & n.a. & n.a. & n.a. \\
\hline CIA (\%) & 85.8 & 75.3 & 85.6 & 66.6 & 76.5 & 71.8 & 95. & 85.4 & 83.4 & 77.4 \\
\hline $\mathrm{Rb}$ (ppm) & 171 & 147 & 179 & 289 & 216 & 213 & 56 & 127 & 105 & 179 \\
\hline $\mathrm{Sr}$ & 26 & 70 & 26 & 109 & 59 & 155 & 4 & 31 & 31 & 79 \\
\hline Cs & 8.2 & 8.0 & 7.1 & 9.9 & 8.5 & 10.1 & 4.4 & 4.6 & 3.6 & 4.8 \\
\hline $\mathrm{Ba}$ & 719 & 587 & 213 & 1200 & 331 & 1190 & 44 & 313 & 297 & 743 \\
\hline $\mathrm{Sn}$ & 2 & 4 & 7 & 1 & 7 & 8 & 6 & 5 & 5 & 6 \\
\hline $\mathrm{Zr}$ & 275 & 98 & 158 & 94 & 86 & 206 & 114 & 112 & 120 & 130 \\
\hline $\mathrm{Hf}$ & 7.5 & 3.3 & 5.4 & 2.1 & 2.8 & 6.2 & 3.6 & 3.7 & 3.9 & 4.3 \\
\hline $\mathrm{Nb}$ & 20.0 & 7.1 & 13.4 & 3.3 & 7.9 & 13.8 & 8.8 & 9.6 & 7.8 & 10.9 \\
\hline $\mathrm{Ta}$ & 1.75 & 1.11 & 1.81 & 0.72 & 1.37 & 1.40 & 1.24 & 1.27 & 1.05 & 1.46 \\
\hline $\mathrm{V}$ & 117 & 27 & 31 & 59 & 30 & 67 & 32 & 37 & 32 & 37 \\
\hline Co & 87 & 75 & 60 & 68 & 39 & 71 & 87 & 98 & 30 & 57 \\
\hline $\mathrm{Zn}$ & 140 & $<30$ & 40 & 100 & $<30$ & 80 & $<30$ & 40 & $<30$ & 40 \\
\hline $\mathrm{Ga}$ & 32 & 19 & 21 & 22 & 17 & 22 & 16 & 19 & 16 & 21 \\
\hline $\mathrm{Ge}$ & 2 & 2 & 2 & 2 & 2 & 2 & 2 & 2 & 1 & 2 \\
\hline $\mathrm{Pb}$ & 31 & 41 & 42 & 54 & 74 & 23 & 11 & 34 & 18 & 46 \\
\hline $\mathrm{Th}$ & 23.0 & 10.8 & 15.8 & 40.2 & 10.7 & 24.4 & 10.0 & 12.7 & 11.5 & 14.0 \\
\hline U & 4.39 & 4.21 & 6.77 & 4.40 & 7.19 & 7.59 & 3.76 & 6.66 & 6.13 & 8.60 \\
\hline $\mathrm{Y}$ & 20.7 & 15.5 & 19.8 & 20.7 & 15.8 & 35.4 & 14.2 & 33.7 & 37.7 & 53.1 \\
\hline $\mathrm{La}$ & 48.0 & 17.8 & 28.5 & 77.3 & 52.8 & 79.0 & 13.6 & 39.5 & 45.8 & 53.4 \\
\hline $\mathrm{Ce}$ & 93.2 & 41.3 & 58.2 & 153 & 79.9 & 132 & 30.0 & 79.5 & 67.0 & 83.2 \\
\hline $\operatorname{Pr}$ & 11.2 & 4.18 & 5.77 & 19.0 & 11.5 & 18.5 & 3.14 & 9.19 & 12.2 & 14.5 \\
\hline $\mathrm{Nd}$ & 35.2 & 12.9 & 17.0 & 56.7 & 32.9 & 56.1 & 9.52 & 27.8 & 37.7 & 46.2 \\
\hline $\mathrm{Sm}$ & 6.42 & 2.64 & 3.15 & 10.9 & 5.77 & 10.7 & 1.86 & 5.67 & 8.09 & 10.4 \\
\hline $\mathrm{Eu}$ & 1.13 & 0.570 & 0.471 & 1.54 & 1.23 & 2.20 & 0.279 & 1.42 & 1.98 & 2.76 \\
\hline $\mathrm{Gd}$ & 5.08 & 2.34 & 2.50 & 8.22 & 4.60 & 8.95 & 1.77 & 5.33 & 7.33 & 9.77 \\
\hline $\mathrm{Tb}$ & 0.80 & 0.44 & 0.50 & 1.11 & 0.69 & 1.39 & 0.34 & 0.95 & 1.20 & 1.74 \\
\hline Dy & 3.94 & 2.45 & 3.06 & 4.61 & 3.31 & 6.80 & 2.06 & 5.39 & 6.42 & 9.60 \\
\hline Ho & 0.71 & 0.49 & 0.64 & 0.70 & 0.54 & 1.23 & 0.44 & 1.04 & 1.22 & 1.80 \\
\hline $\mathrm{Er}$ & 2.00 & 1.50 & 1.96 & 1.83 & 1.43 & 3.36 & 1.44 & 3.08 & 3.66 & 5.44 \\
\hline $\mathrm{Tm}$ & 0.288 & 0.235 & 0.331 & 0.248 & 0.206 & 0.474 & 0.23 & 0.470 & 0.555 & 0.841 \\
\hline $\mathrm{Yb}$ & 1.76 & 1.51 & 2.19 & 1.50 & 1.29 & 2.70 & 1.48 & 2.95 & 3.47 & 5.37 \\
\hline $\mathrm{Lu}$ & 0.258 & 0.220 & 0.329 & 0.219 & 0.180 & 0.381 & 0.236 & 0.429 & 0.501 & 0.749 \\
\hline$\Sigma$ LREE & 195.2 & 79.4 & 113.1 & 318.4 & 184.1 & 298.5 & 58.4 & 163.1 & 172.8 & 210.5 \\
\hline$\Sigma$ HREE & 14.8 & 9.2 & 11.5 & 18.4 & 12.2 & 25.3 & 8.0 & 19.6 & 24.4 & 35.3 \\
\hline$\Sigma$ REE & 210.0 & 88.6 & 124.6 & 336.9 & 196.3 & 323.8 & 66.4 & 182.7 & 197.1 & 245.8 \\
\hline$\Sigma \mathrm{REE}+\mathrm{Y}$ & 230.7 & 104.1 & 144.4 & 357.6 & 212.1 & 359.2 & 80.6 & 216.4 & 234.8 & 298.9 \\
\hline LREE/HREE & 13.2 & 8.6 & 9.8 & 17.3 & 15.0 & 11.8 & 7.3 & 8.3 & 7.1 & 6.0 \\
\hline HREE/REE & 0.07 & 0.10 & 0.09 & 0.05 & 0.06 & 0.08 & 0.12 & 0.11 & 0.12 & 0.14 \\
\hline $\mathrm{Ce} / \mathrm{Ce} *$ & 0.99 & 1.17 & 1.11 & 0.98 & 0.79 & 0.85 & 1.13 & 1.02 & 0.69 & 0.73 \\
\hline $\mathrm{Eu} / \mathrm{Eu}^{*}$ & 0.60 & 0.70 & 0.51 & 0.50 & 0.73 & 0.69 & 0.47 & 0.79 & 0.79 & 0.84 \\
\hline $\mathrm{La}_{N} / \mathrm{Yb}_{\mathrm{N}}$ & 19.6 & 8.5 & 9.3 & 37.0 & 29.4 & 21.0 & 6.6 & 9.6 & 9.5 & 7.1 \\
\hline
\end{tabular}


Appendix 1 Continued.

\begin{tabular}{|c|c|c|c|c|c|c|c|c|c|c|}
\hline Sequential \# & 71 & 72 & 73 & 74 & 75 & 76 & 77 & 78 & 79 & 80 \\
\hline Sample \# & $70112 \mathrm{C}$ & 70113B1 & 70113B2 & 70114B & $70301 \mathrm{~B}$ & $70301 \mathrm{~B}$ & $70302 \mathrm{~A}$ & 70302B1 & $70302 \mathrm{~B} 2$ & 70307A \\
\hline District & Nape & Nape & Nape & Nape & Xaisom. & Xaisom. & Xaisom. & Xaisom. & Xaisom. & Xaisom. \\
\hline Rock type & W Gr & W Gr & W Gr & W Gr & W Gr & W Gr & W Gr & W Gr & W Gr & W Gr \\
\hline Latitude & $18^{\circ} 19.797^{\prime}$ & $18^{\circ} 21169^{\prime}$ & $18^{\circ} 21169^{\prime}$ & $18^{\circ} 22.049^{\prime}$ & $18^{\circ} 40.438^{\prime}$ & $18^{\circ} 40.438^{\prime}$ & $18^{\circ} 40.774^{\prime}$ & $18^{\circ} 40.774^{\prime}$ & $18^{\circ} 40.774^{\prime}$ & $18^{\circ} 43.309^{\prime}$ \\
\hline Longitude & $105^{\circ} 02.066^{\prime}$ & $105^{\circ} 02.232^{\prime}$ & $105^{\circ} 02.232^{\prime}$ & $105^{\circ} 02.012^{\prime}$ & $103^{\circ} 07.166^{\prime}$ & $103^{\circ} 07.166^{\prime}$ & $103^{\circ} 08.376^{\prime}$ & $103^{\circ} 08.376^{\prime}$ & $103^{\circ} 08.376^{\prime}$ & $103^{\circ} 19.850^{\prime}$ \\
\hline $\mathrm{SiO}_{2}(\mathrm{wt} \%)$ & 66.96 & 63.81 & 68.17 & 65.44 & 69.67 & 63.91 & 74.11 & 68.62 & 70.75 & 52.87 \\
\hline $\mathrm{TiO}_{2}$ & 0.34 & 0.34 & 0.35 & 0.44 & 0.22 & 0.16 & 0.22 & 0.27 & 0.25 & 0.89 \\
\hline $\mathrm{Al}_{2} \mathrm{O}_{3}$ & 16.67 & 17.67 & 15.27 & 16.40 & 14.38 & 17.27 & 10.92 & 17.54 & 15.36 & 18.42 \\
\hline $\mathrm{Fe}_{2} \mathrm{O}_{3} *$ & 3.16 & 4.71 & 4.27 & 4.03 & 2.78 & 2.67 & 5.06 & 2.62 & 1.84 & 6.14 \\
\hline $\mathrm{MnO}$ & 0.021 & 0.037 & 0.012 & 0.036 & 0.013 & 0.011 & 0.018 & 0.007 & 0.007 & 0.099 \\
\hline $\mathrm{MgO}$ & 0.43 & 0.15 & 0.22 & 0.73 & 0.18 & 0.25 & 0.21 & 0.37 & 0.26 & 0.51 \\
\hline $\mathrm{CaO}$ & 0.04 & 0.01 & 0.02 & 0.02 & 0.01 & 0.01 & 0.02 & 0.01 & 0.01 & 0.26 \\
\hline $\mathrm{Na}_{2} \mathrm{O}$ & 0.20 & 0.09 & 0.08 & 0.10 & 0.05 & 0.07 & 0.04 & 0.04 & 0.03 & 0.18 \\
\hline $\mathrm{K}_{2} \mathrm{O}$ & 4.46 & 1.52 & 1.73 & 2.17 & 0.81 & 1.33 & 0.77 & 1.52 & 1.18 & 3.31 \\
\hline $\mathrm{P}_{2} \mathrm{O}_{5}$ & 0.05 & 0.06 & 0.03 & 0.04 & 0.04 & 0.05 & 0.06 & 0.03 & 0.03 & 0.12 \\
\hline LOI & 5.47 & 9.72 & 8.49 & 7.51 & 9.40 & 9.94 & 6.51 & 7.52 & 8.06 & 15.57 \\
\hline Total & 97.76 & 98.09 & 98.63 & 96.90 & 97.53 & 95.65 & 97.92 & 98.54 & 97.75 & 98.36 \\
\hline$F(w t \%)$ & n.a. & n.a. & n.a. & n.a. & n.a. & n.a. & n.a. & n.a. & n.a. & n.a. \\
\hline CIA (\%) & 76.1 & 90.7 & 88.2 & 86.5 & 93.6 & 91.7 & 92.1 & 91. & 91.9 & 80.9 \\
\hline $\mathrm{Rb}$ (ppm) & 242 & 92 & 127 & 119 & 88 & 153 & 68 & 143 & 116 & 219 \\
\hline $\mathrm{Sr}$ & 58 & 19 & 16 & 37 & 6 & 6 & 6 & 6 & 4 & 178 \\
\hline Cs & 7.6 & 4.5 & 6.0 & 6.9 & 8.1 & 11.1 & 4.8 & 7.6 & 5.9 & 5.0 \\
\hline $\mathrm{Ba}$ & 684 & 150 & 190 & 543 & 43 & 40 & 57 & 77 & 46 & 961 \\
\hline $\mathrm{Sn}$ & 6 & 10 & 11 & 3 & 20 & 20 & 10 & 38 & 14 & 4 \\
\hline $\mathrm{Zr}$ & 148 & 109 & 126 & 196 & 105 & 90 & 122 & 135 & 134 & 165 \\
\hline $\mathrm{Hf}$ & 4.6 & 3.7 & 4.0 & 6.1 & 4.3 & 3.9 & 4.2 & 4.9 & 4.5 & 5.1 \\
\hline $\mathrm{Nb}$ & 12.2 & 12.0 & 10.6 & 12.1 & 8.7 & 11.6 & 7.1 & 11.3 & 10.2 & 12.4 \\
\hline $\mathrm{Ta}$ & 1.56 & 1.61 & 1.76 & 1.16 & 1.99 & 2.75 & 1.41 & 2.6 & 1.99 & 1.64 \\
\hline $\mathrm{V}$ & 41 & 44 & 46 & 50 & 28 & 44 & 39 & 27 & 18 & 92 \\
\hline Co & 58 & 75 & 48 & 80 & 74 & 58 & 73 & 42 & 38 & 21 \\
\hline $\mathrm{Zn}$ & 40 & 40 & $<30$ & 50 & $<30$ & $<30$ & $<30$ & $<30$ & 150 & 70 \\
\hline $\mathrm{Ga}$ & 20 & 23 & 19 & 21 & 21 & 27 & 16 & 24 & 20 & 23 \\
\hline $\mathrm{Ge}$ & 2 & 2 & 2 & 2 & 2 & 3 & 1 & 2 & 2 & 2 \\
\hline $\mathrm{Pb}$ & 44 & 32 & 17 & 30 & 19 & 22 & 15 & 26 & 26 & 106 \\
\hline $\mathrm{Th}$ & 15.0 & 13.6 & 13.8 & 19.2 & 20.8 & 19.5 & 18.7 & 23.5 & 17.3 & 21.4 \\
\hline $\mathrm{U}$ & 5.82 & 4.95 & 3.57 & 4.63 & 5.14 & 3.86 & 3.11 & 2.69 & 2.6 & 6.65 \\
\hline $\mathrm{Y}$ & 34.9 & 24.4 & 14.4 & 37.4 & 34.6 & 45.1 & 25.5 & 36.5 & 29.8 & 77.9 \\
\hline $\mathrm{La}$ & 37.3 & 34.4 & 21.7 & 49.8 & 12.4 & 9.99 & 14.8 & 21.5 & 28.7 & 232 \\
\hline $\mathrm{Ce}$ & 61.3 & 59.9 & 32.2 & 95.2 & 26.1 & 22.7 & 29.4 & 43.7 & 56.4 & 375 \\
\hline $\operatorname{Pr}$ & 9.66 & 8.37 & 5.07 & 12.5 & 3.21 & 2.77 & 3.64 & 5.25 & 6.43 & 48.7 \\
\hline $\mathrm{Nd}$ & 31.6 & 27.4 & 15.3 & 39.3 & 11.3 & 12.1 & 12.2 & 18.1 & 21.2 & 144.0 \\
\hline $\mathrm{Sm}$ & 6.41 & 5.35 & 2.91 & 7.96 & 2.54 & 2.75 & 2.47 & 3.46 & 3.60 & 26.4 \\
\hline $\mathrm{Eu}$ & 1.72 & 1.27 & 0.686 & 1.62 & 0.186 & 0.160 & 0.298 & 0.371 & 0.361 & 7.50 \\
\hline $\mathrm{Gd}$ & 6.17 & 4.78 & 2.55 & 7.29 & 3.29 & 4.12 & 2.88 & 3.95 & 3.45 & 19.3 \\
\hline $\mathrm{Tb}$ & 1.09 & 0.83 & 0.42 & 1.20 & 0.83 & 1.06 & 0.63 & 0.85 & 0.69 & 2.73 \\
\hline Dy & 6.01 & 4.46 & 2.31 & 6.38 & 5.46 & 7.12 & 3.93 & 5.56 & 4.45 & 13.4 \\
\hline Ho & 1.13 & 0.81 & 0.45 & 1.21 & 1.11 & 1.45 & 0.81 & 1.14 & 0.90 & 2.34 \\
\hline $\mathrm{Er}$ & 3.47 & 2.39 & 1.40 & 3.54 & 3.54 & 4.59 & 2.48 & 3.51 & 2.74 & 6.39 \\
\hline $\mathrm{Tm}$ & 0.547 & 0.372 & 0.221 & 0.530 & 0.603 & 0.752 & 0.386 & 0.543 & 0.425 & 0.888 \\
\hline $\mathrm{Yb}$ & 3.47 & 2.35 & 1.47 & 3.25 & 3.90 & 4.81 & 2.43 & 3.45 & 2.67 & 5.35 \\
\hline $\mathrm{Lu}$ & 0.510 & 0.339 & 0.224 & 0.476 & 0.565 & 0.673 & 0.353 & 0.497 & 0.369 & 0.741 \\
\hline$\Sigma$ LREE & 148.0 & 136.7 & 77.9 & 206.4 & 55.7 & 50.5 & 62.8 & 92.4 & 116.7 & 833.6 \\
\hline$\Sigma$ HREE & 22.4 & 16.3 & 9.0 & 23.9 & 19.3 & 24.6 & 13.9 & 19.5 & 15.7 & 51.1 \\
\hline$\Sigma \mathrm{REE}$ & 170.4 & 153.0 & 86.9 & 230.3 & 75.0 & 75.0 & 76.7 & 111.9 & 132.4 & 884.7 \\
\hline$\Sigma \mathrm{REE}+\mathrm{Y}$ & 205.3 & 177.4 & 101.3 & 267.7 & 109.6 & 120.1 & 102.2 & 148.4 & 162.2 & 962.6 \\
\hline LREE/HREE & 6.6 & 8.4 & 8.6 & 8.6 & 2.9 & 2.1 & 4.5 & 4.7 & 7.4 & 16.3 \\
\hline HREE/REE & 0.13 & 0.11 & 0.10 & 0.10 & 0.26 & 0.33 & 0.18 & 0.17 & 0.12 & 0.06 \\
\hline $\mathrm{Ce} / \mathrm{Ce}^{*}$ & 0.79 & 0.87 & 0.75 & 0.94 & 1.01 & 1.06 & 0.98 & 1.01 & 1.02 & 0.86 \\
\hline $\mathrm{Eu} / \mathrm{Eu}^{*}$ & 0.84 & 0.77 & 0.77 & 0.65 & 0.20 & 0.15 & 0.34 & 0.31 & 0.31 & 1.02 \\
\hline $\mathrm{La}_{\mathrm{N}} / \mathrm{Yb}_{\mathrm{N}}$ & 7.7 & 10.5 & 10.6 & 11.0 & 2.3 & 1.5 & 4.4 & 4.5 & 7.7 & 31.1 \\
\hline
\end{tabular}


Appendix 1 Continued.

\begin{tabular}{|c|c|c|c|c|c|c|c|c|c|c|}
\hline Sequential \# & 81 & 82 & 83 & 84 & 85 & 86 & 87 & 88 & 89 & 90 \\
\hline Sample \# & 70307B1 & 70307B2 & $70307 \mathrm{C}$ & 70308B1 & $70308 \mathrm{~B} 2$ & $70310 \mathrm{~B} 1$ & $70310 \mathrm{~B} 2$ & $70401 \mathrm{~A}$ & 70401B1 & $70401 \mathrm{~B} 2$ \\
\hline $\begin{array}{l}\text { District } \\
\text { Rock type }\end{array}$ & $\begin{array}{l}\text { Xaisom. } \\
\text { W Gr }\end{array}$ & $\begin{array}{l}\text { Xaisom. } \\
\text { W Gr }\end{array}$ & $\begin{array}{l}\text { Xaisom. } \\
\text { W Gr }\end{array}$ & $\begin{array}{l}\text { Xaisom. } \\
\text { W Gr }\end{array}$ & $\begin{array}{l}\text { Xaisom. } \\
\text { W Gr }\end{array}$ & $\begin{array}{l}\text { Xaisom. } \\
\text { W Gr }\end{array}$ & $\begin{array}{l}\text { Xaisom. } \\
\text { W Gr }\end{array}$ & $\begin{array}{l}\text { Xaisom. } \\
\text { W Gr }\end{array}$ & $\begin{array}{l}\text { Xaisom. } \\
\text { W Gr }\end{array}$ & $\begin{array}{l}\text { Xaisom. } \\
\text { W Gr }\end{array}$ \\
\hline Latitude & $18^{\circ} 43.309^{\prime}$ & $18^{\circ} 43.309^{\prime}$ & $18^{\circ} 43.309^{\prime}$ & $18^{\circ} 43.585^{\prime}$ & $18^{\circ} 43.585^{\prime}$ & $18^{\circ} 44.018^{\prime}$ & $18^{\circ} 44.018^{\prime}$ & $18^{\circ} 57.926^{\prime}$ & $18^{\circ} 57.926^{\prime}$ & $18^{\circ} 57.926^{\prime}$ \\
\hline Longitude & $103^{\circ} 19.850^{\prime}$ & $103^{\circ} 19.850^{\prime}$ & $103^{\circ} 19.850^{\prime}$ & $103^{\circ} 24.419^{\prime}$ & $103^{\circ} 24.419^{\prime}$ & $103^{\circ} 25.311^{\prime}$ & $103^{\circ} 25.311^{\prime}$ & $103^{\circ} 18.082^{\prime}$ & $103^{\circ} 18.082^{\prime}$ & $103^{\circ} 18.082^{\prime}$ \\
\hline $\mathrm{SiO}_{2}(\mathrm{wt} \%)$ & 63.44 & 59.87 & 64.03 & 70.38 & 63.65 & 73.23 & 60.99 & 56.93 & 55.36 & 71.38 \\
\hline $\mathrm{TiO}_{2}$ & 0.72 & 0.42 & 0.43 & 0.35 & 0.50 & 0.37 & 0.61 & 0.81 & 0.85 & 0.41 \\
\hline $\mathrm{Al}_{2} \mathrm{O}_{3}$ & 15.49 & 16.63 & 16.65 & 12.32 & 17.58 & 12.07 & 20.74 & 19.22 & 21.19 & 12.62 \\
\hline $\mathrm{Fe}_{2} \mathrm{O}_{3}$ * & 5.22 & 3.61 & 3.34 & 3.27 & 3.63 & 2.99 & 4.07 & 5.32 & 5.51 & 2.95 \\
\hline $\mathrm{MnO}$ & 0.109 & 0.089 & 0.040 & 0.049 & 0.012 & 0.010 & 0.013 & 0.015 & 0.013 & 0.011 \\
\hline $\mathrm{MgO}$ & 0.44 & 0.20 & 0.49 & 0.20 & 0.23 & 0.10 & 0.25 & 0.26 & 0.30 & 0.12 \\
\hline $\mathrm{CaO}$ & 0.23 & 0.04 & 0.06 & 0.04 & 0.03 & 0.01 & 0.01 & 0.02 & 0.01 & 0.01 \\
\hline $\mathrm{Na}_{2} \mathrm{O}$ & 0.15 & 0.09 & 0.24 & 0.08 & 0.17 & 0.04 & 0.06 & 0.08 & 0.09 & 0.03 \\
\hline $\mathrm{K}_{2} \mathrm{O}$ & 3.04 & 4.22 & 6.71 & 1.61 & 4.02 & 0.69 & 2.63 & 1.07 & 1.21 & 0.44 \\
\hline $\mathrm{P}_{2} \mathrm{O}_{5}$ & 0.09 & 0.09 & 0.16 & 0.04 & 0.03 & 0.03 & 0.07 & 0.09 & 0.06 & 0.02 \\
\hline LOI & 8.44 & 12.14 & 4.77 & 8.40 & 7.85 & 7.41 & 9.46 & 14.31 & 13.23 & 9.65 \\
\hline Total & 97.35 & 97.38 & 96.92 & 96.72 & 97.68 & 96.91 & 98.88 & 98.10 & 97.81 & 97.63 \\
\hline$F(w t \%)$ & n.a. & n.a. & n.a. & n.a. & n.a. & n.a. & n.a. & n.a. & n.a. & n.a. \\
\hline CIA (\%) & 79.7 & 77.6 & 68.2 & 86.4 & 79. & 93.6 & 87.5 & 93.5 & 93.5 & 95.9 \\
\hline $\mathrm{Rb}(\mathrm{ppm})$ & 184 & 136 & 291 & 90 & 141 & 73 & 223 & 74 & 67 & 31 \\
\hline $\mathrm{Sr}$ & 154 & 88 & 142 & 20 & 34 & 5 & 8 & 21 & 20 & 7 \\
\hline Cs & 4.2 & 2.3 & 4.9 & 3.0 & 2.4 & 3.7 & 6.2 & 5.9 & 5.8 & 2.6 \\
\hline $\mathrm{Ba}$ & 876 & 598 & 966 & 289 & 775 & 95 & 392 & 157 & 155 & 59 \\
\hline $\mathrm{Sn}$ & 4 & 3 & 3 & 6 & 9 & 5 & 8 & 5 & 5 & 3 \\
\hline $\mathrm{Zr}$ & 159 & 145 & 160 & 208 & 282 & 200 & 332 & 321 & 283 & 200 \\
\hline $\mathrm{Hf}$ & 4.9 & 4.6 & 5.2 & 6.6 & 8.5 & 6.3 & 9.9 & 9.4 & 8.3 & 5.6 \\
\hline $\mathrm{Nb}$ & 10.3 & 8.0 & 8.5 & 10.2 & 15.2 & 8.9 & 15.8 & 21.9 & 21.7 & 13.8 \\
\hline $\mathrm{Ta}$ & 1.31 & 1.2 & 1.45 & 1.22 & 1.84 & 1.08 & 1.65 & 2.55 & 2.51 & 1.8 \\
\hline V & 76 & 53 & 59 & 37 & 40 & 36 & 54 & 83 & 92 & 38 \\
\hline Co & 51 & 17 & 52 & 62 & 71 & 106 & 53 & 34 & 64 & 40 \\
\hline $\mathrm{Zn}$ & 60 & 50 & 40 & 50 & $<30$ & $<30$ & $<30$ & $<30$ & 40 & $<30$ \\
\hline $\mathrm{Ga}$ & 19 & 22 & 25 & 17 & 22 & 16 & 27 & 25 & 29 & 19 \\
\hline $\mathrm{Ge}$ & 2 & 2 & 3 & 2 & 2 & 2 & 1 & 1 & 2 & 1 \\
\hline $\mathrm{Pb}$ & 95 & 47 & 23 & 37 & 54 & 27 & 50 & 17 & 13 & 16 \\
\hline $\mathrm{Th}$ & 21.9 & 21.8 & 27.3 & 26.9 & 34.2 & 25.9 & 33.7 & 30.5 & 29.2 & 23.6 \\
\hline U & 6.18 & 3.85 & 7.33 & 4.67 & 5.48 & 5.33 & 11.5 & 4.93 & 4.68 & 2.99 \\
\hline $\mathrm{Y}$ & 105 & 150 & 164 & 59.8 & 70.4 & 17.4 & 17.2 & 11.6 & 11.1 & 5.8 \\
\hline $\mathrm{La}$ & 325 & 558 & 1290 & 75 & 121 & 33.4 & 34.2 & 23.1 & 21.2 & 11.6 \\
\hline $\mathrm{Ce}$ & 357 & 728 & 1070 & 141 & 110 & 136 & 74.2 & 28.1 & 25.8 & 13.5 \\
\hline $\operatorname{Pr}$ & 66.9 & 137.0 & 255.0 & 18.2 & 28.2 & 7.74 & 8.41 & 4.16 & 3.80 & 1.91 \\
\hline $\mathrm{Nd}$ & 195.0 & 394.0 & 764.0 & 58.8 & 84.3 & 22.5 & 24.2 & 11.3 & 11.5 & 5.05 \\
\hline $\mathrm{Sm}$ & 33.6 & 68.3 & 113.0 & 12.0 & 16.7 & 4.29 & 4.64 & 1.93 & 2.07 & 0.85 \\
\hline $\mathrm{Eu}$ & 9.39 & 17.7 & 29.7 & 2.01 & 2.67 & 0.599 & 0.571 & 0.416 & 0.395 & 0.149 \\
\hline $\mathrm{Gd}$ & 26.1 & 43.9 & 71.3 & 11.5 & 15.9 & 3.33 & 3.60 & 1.78 & 1.89 & 0.81 \\
\hline $\mathrm{Tb}$ & 3.43 & 5.73 & 7.64 & 1.93 & 2.25 & 0.58 & 0.65 & 0.31 & 0.29 & 0.14 \\
\hline Dy & 16.8 & 27.9 & 33.0 & 9.79 & 11.4 & 3.14 & 3.45 & 1.84 & 1.82 & 0.84 \\
\hline Но & 2.87 & 4.45 & 5.20 & 1.82 & 2.10 & 0.61 & 0.66 & 0.40 & 0.39 & 0.19 \\
\hline $\mathrm{Er}$ & 7.88 & 11.6 & 13.2 & 5.27 & 6.09 & 1.91 & 2.15 & 1.34 & 1.36 & 0.66 \\
\hline $\mathrm{Tm}$ & 1.05 & 1.48 & 1.63 & 0.769 & 0.890 & 0.314 & 0.365 & 0.233 & 0.226 & 0.120 \\
\hline $\mathrm{Yb}$ & 6.08 & 8.70 & 9.42 & 4.66 & 5.40 & 2.01 & 2.50 & 1.68 & 1.68 & 0.91 \\
\hline $\mathrm{Lu}$ & 0.818 & 1.09 & 1.21 & 0.678 & 0.761 & 0.306 & 0.379 & 0.294 & 0.293 & 0.163 \\
\hline$\Sigma$ LREE & 986.9 & 1903.0 & 3521.7 & 307.0 & 362.9 & 204.5 & 146.2 & 69.0 & 64.8 & 33.1 \\
\hline$\Sigma$ HREE & 65.0 & 104.9 & 142.6 & 36.4 & 44.8 & 12.2 & 13.8 & 7.9 & 7.9 & 3.8 \\
\hline$\Sigma \mathrm{REE}$ & 1051.9 & 2007.9 & 3664.3 & 343.4 & 407.7 & 216.7 & 160.0 & 76.9 & 72.7 & 36.9 \\
\hline$\Sigma \mathrm{REE}+\mathrm{Y}$ & 1156.9 & 2157.9 & 3828.3 & 403.2 & 478.1 & 234.1 & 177.2 & 88.5 & 83.8 & 42.7 \\
\hline LREE/HREE & 15.2 & 18.1 & 24.7 & 8.4 & 8.1 & 16.8 & 10.6 & 8.8 & 8.1 & 8.6 \\
\hline HREE/REE & 0.06 & 0.05 & 0.04 & 0.11 & 0.11 & 0.06 & 0.09 & 0.10 & 0.11 & 0.10 \\
\hline $\mathrm{Ce} / \mathrm{Ce} *$ & 0.59 & 0.65 & 0.46 & 0.94 & 0.46 & 2.07 & 1.07 & 0.70 & 0.70 & 0.70 \\
\hline $\mathrm{Eu} / \mathrm{Eu}^{*}$ & 0.97 & 0.99 & 1.01 & 0.52 & 0.50 & 0.48 & 0.43 & 0.69 & 0.61 & 0.55 \\
\hline $\mathrm{La}_{N} / \mathrm{Yb}_{\mathrm{N}}$ & 38.3 & 46.0 & 98.2 & 11.5 & 16.1 & 11.9 & 9.8 & 9.9 & 9.1 & 9.1 \\
\hline
\end{tabular}


Appendix 1 Continued.

\begin{tabular}{|c|c|c|c|c|c|c|c|c|c|c|}
\hline Sequential \# & 91 & 92 & 93 & 94 & 95 & 96 & 97 & 98 & 99 & 100 \\
\hline Sample \# & $70403 B$ & 70404B & P719CL1 & P719CL2 & P719CL3 & P788CL & P798CL & P799CL & $62804 \mathrm{CL}$ & $62806 \mathrm{CL}$ \\
\hline District & Xaisom. & Xaisom. & Attapu & Attapu & Attapu & Attapu & Boneng & Boneng & Boneng & Boneng \\
\hline Rock type & W Gr & W Gr & Kln-rich & Kln-rich & Kln-rich & Kln-rich & Kln-rich & Kln-rich & Kln-rich & Kln-rich \\
\hline Latitude & $18^{\circ} 58.480^{\prime}$ & $18^{\circ} 52.091^{\prime}$ & $14^{\circ} 42.297^{\prime}$ & $14^{\circ} 42.297^{\prime}$ & $14^{\circ} 42.297^{\prime}$ & $14^{\circ} 47.868^{\prime}$ & $17^{\circ} 53.049^{\prime}$ & $17^{\circ} 53.059^{\prime}$ & $17^{\circ} 58.730^{\prime}$ & $17^{\circ} 58.730^{\prime}$ \\
\hline Longitude & $103^{\circ} 19.385^{\prime}$ & $102^{\circ} 54.454^{\prime}$ & $107^{\circ} 32.964^{\prime}$ & $107^{\circ} 32.964^{\prime}$ & $107^{\circ} 32.964^{\prime}$ & $107^{\circ} 29.359^{\prime}$ & $104^{\circ} 36.243^{\prime}$ & $104^{\circ} 36.254^{\prime}$ & $104^{\circ} 18.5^{\prime}$ & $104^{\circ} 18.5^{\prime}$ \\
\hline $\mathrm{SiO}_{2}(\mathrm{wt} \%)$ & 73.54 & 87.78 & 74.97 & 72.20 & 72.30 & 57.47 & 34.92 & 38.31 & 51.93 & 55.25 \\
\hline $\mathrm{TiO}_{2}$ & 0.21 & 0.08 & 0.04 & 0.26 & 0.24 & 0.68 & 0.94 & 0.83 & 0.23 & 0.27 \\
\hline $\mathrm{Al}_{2} \mathrm{O}_{3}$ & 14.17 & 5.99 & 16.71 & 17.97 & 17.20 & 22.96 & 26.27 & 31.25 & 25.80 & 24.93 \\
\hline $\mathrm{Fe}_{2} \mathrm{O}_{3} *$ & 1.92 & 0.85 & 0.43 & 1.89 & 1.73 & 5.22 & 22.94 & 12.99 & 3.09 & 3.35 \\
\hline $\mathrm{MnO}$ & 0.012 & 0.004 & 0.038 & 0.002 & 0.006 & 0.011 & 0.040 & 0.087 & 0.011 & 0.007 \\
\hline $\mathrm{MgO}$ & 0.20 & 0.17 & 0.37 & 0.17 & 0.29 & 0.61 & 0.62 & 0.88 & 0.26 & 0.27 \\
\hline $\mathrm{CaO}$ & 0.01 & 0.01 & $<0.01$ & 0.03 & 0.01 & 0.03 & 0.04 & 0.07 & 0.02 & 0.04 \\
\hline $\mathrm{Na}_{2} \mathrm{O}$ & 0.08 & 0.04 & 0.05 & 0.07 & 0.03 & 0.16 & 0.04 & 0.08 & 0.03 & 0.05 \\
\hline $\mathrm{K}_{2} \mathrm{O}$ & 0.62 & 0.97 & 2.74 & 0.18 & 0.23 & 5.24 & 1.56 & 7.26 & 1.44 & 1.53 \\
\hline $\mathrm{P}_{2} \mathrm{O}_{5}$ & $<0.01$ & 0.02 & $<0.01$ & 0.02 & 0.02 & 0.09 & 0.12 & 0.19 & 0.03 & 0.04 \\
\hline LOI & 8.06 & 2.40 & 4.83 & 7.49 & 8.03 & 7.76 & 12.55 & 8.47 & 14.63 & 13.75 \\
\hline Total & 98.80 & 98.29 & 100.18 & 100.30 & 100.09 & 100.23 & 100.04 & 100.41 & 97.44 & 99.47 \\
\hline $\mathrm{F}(\mathrm{wt} \%)$ & n.a. & n.a. & 0.08 & n.a. & 0.02 & 0.04 & 0.04 & 0.03 & n.a. & n.a. \\
\hline CIA (\%) & 94.5 & 84.1 & 84.5 & 98 & 98.2 & 79.3 & 93.5 & 79.4 & 94 & 93.2 \\
\hline $\mathrm{Rb}$ (ppm) & 47 & 56 & 386 & 32 & 36 & 192 & 92 & 360 & 105 & 105 \\
\hline $\mathrm{Sr}$ & 3 & 5 & $<2$ & $<2$ & $<2$ & 159 & 48 & 494 & 6 & 7 \\
\hline Cs & 2.8 & 2.8 & 20 & 3.4 & 3.8 & 2.1 & 6.6 & 16.7 & 4.3 & 4.2 \\
\hline $\mathrm{Ba}$ & 78 & 76 & 11 & $<3$ & 4 & 1430 & 72 & 390 & 239 & 268 \\
\hline $\mathrm{Sn}$ & 6 & 3 & 14 & 5 & 7 & 4 & 846 & 20 & 4 & 4 \\
\hline $\mathrm{Zr}$ & 118 & 53 & 52 & 104 & 131 & 511 & 155 & 114 & 171 & 200 \\
\hline $\mathrm{Hf}$ & 2.1 & 1.9 & 3.0 & 3.9 & 4.2 & 11.6 & 4.2 & 3.3 & 5.4 & 6.2 \\
\hline $\mathrm{Nb}$ & 10.8 & 2.2 & 31.3 & 18.0 & 23.6 & 19.2 & 15.8 & 15.5 & 11.8 & 13.3 \\
\hline $\mathrm{Ta}$ & 0.49 & 0.42 & 9.07 & 4.1 & 4.67 & 0.90 & 1.64 & 1.62 & 1.25 & 1.28 \\
\hline V & 15 & 22 & $<5$ & 16 & 22 & 40 & 205 & 153 & 22 & 23 \\
\hline Co & 71 & 90 & $<1$ & 1 & 2 & 4 & 7 & 4 & 51 & 49 \\
\hline $\mathrm{Zn}$ & 30 & $<30$ & $<30$ & $<30$ & $<30$ & 40 & 230 & 160 & 70 & 60 \\
\hline $\mathrm{Ga}$ & 17 & 7 & 26 & 15 & 20 & 28 & 37 & 31 & 27 & 28 \\
\hline $\mathrm{Ge}$ & 2 & 1 & 2 & $<1$ & 1 & 1 & 4 & 2 & 2 & 2 \\
\hline $\mathrm{Pb}$ & 5 & 12 & 73 & 18 & 19 & 27 & 378 & 127 & 54 & 50 \\
\hline Th & 4.61 & 5.98 & 14.0 & 23.9 & 26.4 & 31.2 & 27.9 & 24.6 & 25.6 & 26.3 \\
\hline $\mathrm{U}$ & 1.05 & 1.74 & 5.19 & 7.2 & 7.88 & 3.35 & 5.43 & 6.24 & 3.12 & 3.13 \\
\hline $\mathrm{Y}$ & 7.4 & 16.5 & 52.8 & 34 & 44.1 & 30.9 & 11.8 & 8.5 & 35.4 & 36.3 \\
\hline $\mathrm{La}$ & 10.7 & 9.87 & 14.5 & 24.1 & 29.2 & 107 & 51.2 & 12.2 & 79.8 & 74.6 \\
\hline $\mathrm{Ce}$ & 20.6 & 19.0 & 40.4 & 65.1 & 83.8 & 190 & 87.9 & 161 & 89.1 & 73.6 \\
\hline $\mathrm{Pr}$ & 2.87 & 2.61 & 4.08 & 5.83 & 7.15 & 20.0 & 8.02 & 2.19 & 17.6 & 16.7 \\
\hline $\mathrm{Nd}$ & 10.4 & 9.45 & 17.9 & 23.8 & 26.0 & 65.7 & 24.7 & 7.31 & 50.9 & 48.1 \\
\hline $\mathrm{Sm}$ & 2.09 & 2.18 & 5.25 & 6.1 & 6.76 & 11.1 & 3.85 & 1.56 & 8.7 & 8.36 \\
\hline $\mathrm{Eu}$ & 0.329 & 0.316 & 0.263 & 0.41 & 0.497 & 2.35 & 0.864 & 0.445 & 1.15 & 1.11 \\
\hline $\mathrm{Gd}$ & 2.15 & 2.31 & 6.07 & 5.1 & 6.62 & 7.54 & 2.27 & 2.40 & 7.89 & 7.66 \\
\hline $\mathrm{Tb}$ & 0.41 & 0.42 & 1.27 & 1.0 & 1.22 & 1.23 & 0.43 & 0.29 & 1.14 & 1.11 \\
\hline Dy & 2.60 & 2.58 & 8.14 & 6.3 & 7.48 & 6.28 & 2.61 & 1.82 & 6.04 & 5.97 \\
\hline Ho & 0.52 & 0.54 & 1.61 & 1.4 & 1.45 & 1.12 & 0.49 & 0.38 & 1.15 & 1.13 \\
\hline $\mathrm{Er}$ & 1.58 & 1.62 & 4.97 & 4.1 & 4.60 & 3.01 & 1.43 & 1.29 & 3.52 & 3.53 \\
\hline $\mathrm{Tm}$ & 0.24 & 0.243 & 0.815 & 0.62 & 0.777 & 0.412 & 0.228 & 0.24 & 0.544 & 0.536 \\
\hline $\mathrm{Yb}$ & 1.57 & 1.53 & 5.32 & 4.10 & 5.03 & 2.55 & 1.55 & 1.80 & 3.42 & 3.36 \\
\hline $\mathrm{Lu}$ & 0.223 & 0.219 & 0.797 & 0.58 & 0.707 & 0.368 & 0.235 & 0.284 & 0.499 & 0.506 \\
\hline$\Sigma$ LREE & 47.0 & 43.4 & 82.4 & 125.3 & 153.4 & 396.2 & 176.5 & 184.7 & 247.3 & 222.5 \\
\hline$\Sigma$ HREE & 9.3 & 9.5 & 29.0 & 23.2 & 27.9 & 22.5 & 9.2 & 8.5 & 24.2 & 23.8 \\
\hline$\Sigma \mathrm{REE}$ & 56.3 & 52.9 & 111.4 & 148.5 & 181.3 & 418.7 & 185.8 & 193.2 & 271.5 & 246.3 \\
\hline$\Sigma \mathrm{REE}+\mathrm{Y}$ & 63.7 & 69.4 & 164.2 & 182.5 & 225.4 & 449.6 & 197.6 & 201.7 & 306.9 & 282.6 \\
\hline LREE/HREE & 5.1 & 4.6 & 2.8 & 5.4 & 5.5 & 17.6 & 19.1 & 21.7 & 10.2 & 9.3 \\
\hline HREE/REE & 0.17 & 0.18 & 0.26 & 0.16 & 0.15 & 0.05 & 0.05 & 0.04 & 0.09 & 0.10 \\
\hline $\mathrm{Ce} / \mathrm{Ce} *$ & 0.91 & 0.92 & 1.29 & 1.35 & 1.42 & 1.01 & 1.06 & 7.64 & 0.58 & 0.51 \\
\hline $\mathrm{Eu} / \mathrm{Eu}^{*}$ & 0.47 & 0.43 & 0.14 & 0.22 & 0.23 & 0.79 & 0.89 & 0.70 & 0.42 & 0.42 \\
\hline $\mathrm{La}_{N} / \mathrm{Yb}_{\mathrm{N}}$ & 4.9 & 4.6 & 2.0 & 4.2 & 4.2 & 30.1 & 23.7 & 4.9 & 16.7 & 15.9 \\
\hline
\end{tabular}


Appendix 1 Continued.

\begin{tabular}{|c|c|c|c|c|c|c|c|c|c|c|}
\hline $\begin{array}{l}\text { Sequential \# } \\
\text { Sample \# }\end{array}$ & $\begin{array}{c}101 \\
62811 \mathrm{~S}\end{array}$ & $\begin{array}{c}102 \\
62812 \mathrm{~S}\end{array}$ & $\begin{array}{c}103 \\
62813 \mathrm{~S}\end{array}$ & $\begin{array}{c}104 \\
62813 \mathrm{~S}\end{array}$ & $\begin{array}{c}105 \\
62813 \mathrm{~S}\end{array}$ & $\begin{array}{c}106 \\
62816 \mathrm{~S}\end{array}$ & $\begin{array}{c}107 \\
62817 \mathrm{~S}\end{array}$ & $\begin{array}{c}108 \\
62819 \mathrm{~S}\end{array}$ & $\begin{array}{c}109 \\
62902 \mathrm{~S}\end{array}$ & $\begin{array}{c}110 \\
70110 \mathrm{~S}\end{array}$ \\
\hline District & Boneng & Boneng & Boneng & Boneng & Boneng & Boneng & Boneng & Boneng & Nape & Nape \\
\hline Rock type & Sediment & Sediment & Sediment & Sediment & Sediment & Sediment & Sediment & Sediment & Sediment & Sediment \\
\hline Latitude & $18^{\circ} 0.057^{\prime}$ & $17^{\circ} 59.808^{\prime}$ & $17^{\circ} 58.994^{\prime}$ & $17^{\circ} 58.994^{\prime}$ & $17^{\circ} 58.994^{\prime}$ & $18^{\circ} 10.191^{\prime}$ & $18^{\circ} 10.239^{\prime}$ & $18^{\circ} 9$ & $18^{\circ} 09.560^{\prime}$ & $18^{\circ} 17.302^{\prime}$ \\
\hline Longitude & $104^{\circ} 17.972^{\prime}$ & $104^{\circ} 17.884^{\prime}$ & $104^{\circ} 18.808^{\prime}$ & $104^{\circ} 18.808^{\prime}$ & $104^{\circ} 18.808^{\prime}$ & $104^{\circ} 17.101^{\prime}$ & $104^{\circ} 17.118^{\prime}$ & $104^{\circ} 17^{\prime}$ & $105^{\circ} 10.150^{\prime}$ & $105^{\circ} 2.844^{\prime}$ \\
\hline $\mathrm{SiO}_{2}(\mathrm{wt} \%)$ & 74.09 & 66.73 & 63.58 & 67.83 & 33.27 & 67.42 & 70.05 & 87.04 & 73.92 & 57.48 \\
\hline $\mathrm{TiO}_{2}$ & 0.52 & 1.11 & 0.86 & 0.79 & 0.61 & 0.69 & 0.51 & 1.43 & 0.34 & 0.86 \\
\hline $\mathrm{Al}_{2} \mathrm{O}_{3}$ & 12.71 & 15.62 & 15.12 & 12.78 & 15.52 & 12.62 & 12.60 & 4.55 & 11.77 & 18.06 \\
\hline $\mathrm{Fe}_{2} \mathrm{O}_{3}$ * & 2.34 & 3.41 & 5.92 & 4.49 & 34.85 & 4.82 & 3.38 & 2.14 & 2.72 & 6.43 \\
\hline $\mathrm{MnO}$ & 0.021 & 0.042 & 0.006 & 0.005 & 0.011 & 0.025 & 0.021 & 0.067 & 0.039 & 0.023 \\
\hline $\mathrm{MgO}$ & 0.22 & 0.11 & 0.57 & 0.46 & 0.53 & 0.28 & 0.18 & 0.36 & 0.65 & 0.23 \\
\hline $\mathrm{CaO}$ & 0.02 & 0.02 & 0.02 & 0.01 & 0.01 & 0.02 & 0.02 & 0.09 & 0.24 & 0.01 \\
\hline $\mathrm{Na}_{2} \mathrm{O}$ & 0.06 & 0.03 & 0.11 & 0.15 & 0.15 & 0.11 & 0.07 & 0.19 & 0.64 & 0.06 \\
\hline $\mathrm{K}_{2} \mathrm{O}$ & 0.87 & 0.47 & 3.20 & 2.79 & 3.39 & 1.12 & 0.71 & 0.28 & 4.13 & 0.80 \\
\hline $\mathrm{P}_{2} \mathrm{O}_{5}$ & 0.04 & 0.08 & 0.07 & 0.07 & 0.11 & 0.07 & 0.06 & 0.03 & 0.09 & 0.04 \\
\hline LOI & 7.22 & 10.61 & 8.54 & 9.39 & 11.04 & 10.88 & 8.91 & 1.57 & 3.98 & 14.40 \\
\hline Total & 98.09 & 98.20 & 97.98 & 98.75 & 99.49 & 98.05 & 96.50 & 97.73 & 98.50 & 98.39 \\
\hline$F(w t \%)$ & n.a. & n.a. & n.a. & n.a. & n.a. & n.a. & n.a. & n.a. & n.a. & n.a. \\
\hline CIA (\%) & 92.2 & 96.3 & 80.4 & 79.6 & 79.8 & 89.8 & 93.2 & 85.4 & 66.4 & 94.8 \\
\hline $\mathrm{Rb}$ (ppm) & 61 & 40 & 196 & 162 & 174 & 84 & 67 & 24 & 228 & 38 \\
\hline $\mathrm{Sr}$ & 9 & 12 & 55 & 49 & 48 & 15 & 21 & 13 & 68 & 15 \\
\hline Cs & 4.3 & 2.0 & 12.4 & 10.1 & 8.7 & 8.2 & 9.2 & 2.0 & 12.6 & 8.2 \\
\hline $\mathrm{Ba}$ & 98 & 104 & 279 & 284 & 350 & 225 & 115 & 49 & 568 & 213 \\
\hline $\mathrm{Sn}$ & 4 & 6 & 5 & 5 & 5 & 19 & 8 & 8 & 10 & 6 \\
\hline $\mathrm{Zr}$ & 493 & 568 & 345 & 295 & 160 & 383 & 410 & 713 & 222 & 339 \\
\hline $\mathrm{Hf}$ & 13.4 & 15.6 & 10.1 & 8.7 & 4.9 & 11.1 & 12.3 & 20.3 & 6.5 & 9.8 \\
\hline $\mathrm{Nb}$ & 14.1 & 21.6 & 17.3 & 13.9 & 11.8 & 13.9 & 14.0 & 21.8 & 11.4 & 16.5 \\
\hline $\mathrm{Ta}$ & 1.40 & 1.93 & 1.67 & 1.49 & 1.16 & 1.63 & 1.74 & 2.2 & 2.05 & 1.6 \\
\hline $\mathrm{V}$ & 48 & 53 & 107 & 81 & 104 & 77 & 41 & 33 & 36 & 119 \\
\hline Co & 42 & 42 & 29 & 39 & 24 & 64 & 80 & 156 & 90 & 46 \\
\hline $\mathrm{Zn}$ & 50 & 80 & 40 & 30 & 140 & 40 & 40 & 70 & 60 & 70 \\
\hline $\mathrm{Ga}$ & 21 & 20 & 23 & 19 & 22 & 21 & 21 & 11 & 16 & 25 \\
\hline $\mathrm{Ge}$ & 1 & 1 & 2 & 2 & 2 & 2 & 1 & 1 & 2 & 2 \\
\hline $\mathrm{Pb}$ & 26 & 32 & 31 & 28 & 47 & 33 & 25 & 164 & 32 & 17 \\
\hline $\mathrm{Th}$ & 13.7 & 16.8 & 20.9 & 17.2 & 18.8 & 20.0 & 21.8 & 10.6 & 14.6 & 22.6 \\
\hline U & 3.50 & 3.98 & 4.18 & 3.74 & 5.10 & 5.17 & 6.24 & 2.51 & 4.32 & 4.56 \\
\hline $\mathrm{Y}$ & 13.1 & 15.3 & 32.6 & 29.6 & 24.5 & 18.1 & 19.6 & 13.3 & 24.1 & 19.4 \\
\hline $\mathrm{La}$ & 22.7 & 36.3 & 50.2 & 41.1 & 42.9 & 25.5 & 40.0 & 24.2 & 33.9 & 17.1 \\
\hline $\mathrm{Ce}$ & 51.8 & 71.1 & 98.3 & 81.6 & 84.3 & 43.4 & 75.1 & 47.9 & 68.7 & 47.7 \\
\hline $\operatorname{Pr}$ & 4.92 & 7.49 & 11.7 & 9.59 & 10.0 & 5.53 & 8.85 & 5.52 & 8.22 & 3.74 \\
\hline $\mathrm{Nd}$ & 14.8 & 21.3 & 35.5 & 29.2 & 30.8 & 16.3 & 26.0 & 16.6 & 25.4 & 11.1 \\
\hline $\mathrm{Sm}$ & 2.75 & 3.79 & 6.40 & 5.44 & 5.50 & 3.03 & 4.76 & 2.78 & 4.94 & 2.25 \\
\hline $\mathrm{Eu}$ & 0.544 & 0.765 & 1.21 & 1.12 & 1.07 & 0.506 & 0.578 & 0.316 & 0.836 & 0.494 \\
\hline $\mathrm{Gd}$ & 2.13 & 3.17 & 5.51 & 4.88 & 4.45 & 2.80 & 4.14 & 2.43 & 4.45 & 2.55 \\
\hline $\mathrm{Tb}$ & 0.38 & 0.52 & 0.97 & 0.87 & 0.75 & 0.51 & 0.68 & 0.37 & 0.73 & 0.47 \\
\hline Dy & 2.17 & 2.81 & 5.43 & 4.90 & 4.17 & 3.03 & 3.61 & 2.06 & 3.90 & 2.89 \\
\hline Ho & 0.46 & 0.56 & 1.08 & 1.00 & 0.84 & 0.62 & 0.67 & 0.45 & 0.74 & 0.63 \\
\hline $\mathrm{Er}$ & 1.57 & 1.86 & 3.36 & 3.08 & 2.55 & 1.99 & 2.08 & 1.51 & 2.27 & 2.05 \\
\hline $\mathrm{Tm}$ & 0.271 & 0.314 & 0.516 & 0.469 & 0.392 & 0.335 & 0.334 & 0.269 & 0.351 & 0.335 \\
\hline $\mathrm{Yb}$ & 1.98 & 2.26 & 3.27 & 3.00 & 2.49 & 2.25 & 2.22 & 1.89 & 2.22 & 2.24 \\
\hline $\mathrm{Lu}$ & 0.340 & 0.384 & 0.505 & 0.442 & 0.360 & 0.352 & 0.346 & 0.326 & 0.324 & 0.367 \\
\hline$\Sigma$ LREE & 97.5 & 140.7 & 203.3 & 168.1 & 174.6 & 94.3 & 155.3 & 97.3 & 142.0 & 82.4 \\
\hline$\Sigma$ HREE & 9.3 & 11.9 & 20.6 & 18.6 & 16.0 & 11.9 & 14.1 & 9.3 & 15.0 & 11.5 \\
\hline$\Sigma$ REE & 106.8 & 152.6 & 224.0 & 186.7 & 190.6 & 106.2 & 169.4 & 106.6 & 157.0 & 93.9 \\
\hline$\Sigma \mathrm{REE}+\mathrm{Y}$ & 119.9 & 167.9 & 256.6 & 216.3 & 215.1 & 124.3 & 189.0 & 119.9 & 181.1 & 113.3 \\
\hline LREE/HREE & 10.5 & 11.8 & 9.8 & 9.0 & 10.9 & 7.9 & 11.0 & 10.5 & 9.5 & 7.1 \\
\hline HREE/REE & 0.09 & 0.08 & 0.09 & 0.10 & 0.08 & 0.11 & 0.08 & 0.09 & 0.10 & 0.12 \\
\hline $\mathrm{Ce} / \mathrm{Ce} *$ & 1.20 & 1.06 & 0.99 & 1.01 & 1.00 & 0.90 & 0.98 & 1.02 & 1.01 & 1.46 \\
\hline $\mathrm{Eu} / \mathrm{Eu}^{*}$ & 0.69 & 0.67 & 0.62 & 0.66 & 0.66 & 0.53 & 0.40 & 0.37 & 0.55 & 0.63 \\
\hline $\mathrm{La}_{\mathrm{N}} / \mathrm{Yb}_{\mathrm{N}}$ & 8.2 & 11.5 & 11.0 & 9.8 & 12.4 & 8.1 & 12.9 & 9.2 & 11.0 & 5.5 \\
\hline
\end{tabular}


Appendix 1 Continued.

\begin{tabular}{|c|c|c|c|c|}
\hline Sequential \# & 111 & 112 & 113 & 114 \\
\hline Sample \# & P797OR1 & P797OR2 & P797CN1 & P797CN2 \\
\hline District & Boneng & Boneng & Boneng & Boneng \\
\hline Rock type & Sn ore & Sn ore & Sn Conc & Sn Conc \\
\hline Latitude & $17^{\circ} 53.027^{\prime}$ & $17^{\circ} 53.027^{\prime}$ & $17^{\circ} 53.027^{\prime}$ & $17^{\circ} 53.027^{\prime}$ \\
\hline Longitude & $104^{\circ} 36.432^{\prime}$ & $104^{\circ} 36.432^{\prime}$ & $104^{\circ} 36.432^{\prime}$ & $104^{\circ} 36.432^{\prime}$ \\
\hline $\mathrm{SiO}_{2}(\mathrm{wt} \%)$ & 75.29 & 86.83 & 9.74 & 16.71 \\
\hline $\mathrm{TiO}_{2}$ & 0.67 & 0.34 & 1.73 & 0.40 \\
\hline $\mathrm{Al}_{2} \mathrm{O}_{3}$ & 10.89 & 5.52 & 2.85 & 4.38 \\
\hline $\mathrm{Fe}_{2} \mathrm{O}_{3}$ * & 4.80 & 3.94 & 36.28 & 60.15 \\
\hline $\mathrm{MnO}$ & 0.009 & 0.006 & 0.542 & 0.671 \\
\hline $\mathrm{MgO}$ & 0.41 & 0.19 & 0.16 & 0.21 \\
\hline $\mathrm{CaO}$ & 0.04 & 0.04 & 0.10 & 0.06 \\
\hline $\mathrm{Na}_{2} \mathrm{O}$ & 0.07 & 0.03 & 0.09 & 0.20 \\
\hline $\mathrm{K}_{2} \mathrm{O}$ & 1.51 & 0.55 & 0.21 & 0.42 \\
\hline $\mathrm{P}_{2} \mathrm{O}_{5}$ & 0.08 & 0.04 & 0.25 & 0.62 \\
\hline LOI & 6.32 & 2.88 & 7.78 & 10.35 \\
\hline Total & 100.09 & 100.37 & 59.73 & 94.17 \\
\hline $\mathrm{F}(\mathrm{wt} \%)$ & 0.03 & 0.03 & 0.01 & 0.02 \\
\hline CIA (\%) & 85.7 & 88.5 & 83.6 & 83.1 \\
\hline $\mathrm{Rb}$ (ppm) & 102 & 33 & 12 & 16 \\
\hline $\mathrm{Sr}$ & 19 & 5 & 20 & 20 \\
\hline Cs & 13.8 & 2.9 & 1.5 & 1.9 \\
\hline $\mathrm{Ba}$ & 196 & 59 & 205 & 284 \\
\hline $\mathrm{Sn}$ & 130 & 164 & $>1000$ & $>1000$ \\
\hline $\mathrm{Zr}$ & 383 & 223 & $>10000$ & 1020 \\
\hline $\mathrm{Hf}$ & 10.0 & 5.7 & 706 & 28.0 \\
\hline $\mathrm{Nb}$ & 11.6 & 5.4 & 50.1 & 7.5 \\
\hline $\mathrm{Ta}$ & 1.22 & 0.67 & 4.42 & 0.75 \\
\hline $\mathrm{V}$ & 75 & 33 & 224 & 179 \\
\hline Co & $<1$ & $<1$ & 35 & 36 \\
\hline $\mathrm{Zn}$ & 70 & 80 & 1080 & 1210 \\
\hline $\mathrm{Ga}$ & 15 & 6 & 14 & 12 \\
\hline $\mathrm{Ge}$ & 1 & 1 & 1 & 1 \\
\hline $\mathrm{Pb}$ & 75 & 40 & 1030 & 1020 \\
\hline Th & 16.8 & 8.9 & 51.2 & 11.6 \\
\hline $\mathrm{U}$ & 2.81 & 1.64 & 45.1 & 5.88 \\
\hline $\mathrm{Y}$ & 14.1 & 5.5 & 244 & 42.9 \\
\hline $\mathrm{La}$ & 44.4 & 13.1 & 96.5 & 25.5 \\
\hline $\mathrm{Ce}$ & 85.9 & 22.8 & 177 & 46.8 \\
\hline $\operatorname{Pr}$ & 8.69 & 2.16 & 19.1 & 5.76 \\
\hline $\mathrm{Nd}$ & 29.8 & 7.19 & 68.8 & 22.3 \\
\hline $\mathrm{Sm}$ & 4.93 & 1.17 & 13.8 & 5.08 \\
\hline $\mathrm{Eu}$ & 1.04 & 0.25 & 2.77 & 1.31 \\
\hline$\overline{\mathrm{Gd}}$ & 3.58 & 0.88 & 17.7 & 5.55 \\
\hline $\mathrm{Tb}$ & 0.56 & 0.16 & 4.17 & 1.12 \\
\hline Dy & 2.95 & 1.03 & 29.8 & 7.14 \\
\hline Ho & 0.53 & 0.22 & 7.09 & 1.49 \\
\hline Er & 1.57 & 0.68 & 26.6 & 4.65 \\
\hline $\mathrm{Tm}$ & 0.243 & 0.122 & 5.03 & 0.752 \\
\hline $\mathrm{Yb}$ & 1.75 & 0.89 & 38.9 & 5.13 \\
\hline$\underline{\mathrm{Lu}}$ & 0.315 & 0.156 & 7.50 & 0.812 \\
\hline$\Sigma$ LREE & 174.8 & 46.7 & 378.0 & 106.8 \\
\hline$\Sigma$ HREE & 11.5 & 4.1 & 136.8 & 26.6 \\
\hline$\Sigma$ REE & 186.3 & 50.8 & 514.8 & 133.4 \\
\hline$\Sigma \mathrm{REE}+\mathrm{Y}$ & 200.4 & 56.3 & 758.8 & 176.3 \\
\hline LREE/HREE & 15.2 & 11.3 & 2.8 & 4.0 \\
\hline HREE/REE & 0.06 & 0.08 & 0.27 & 0.20 \\
\hline $\mathrm{Ce} / \mathrm{Ce}^{*}$ & 1.07 & 1.05 & 1.01 & 0.95 \\
\hline $\mathrm{Eu} / \mathrm{Eu}^{*}$ & 0.76 & 0.75 & 0.54 & 0.75 \\
\hline $\mathrm{La}_{\mathrm{N}} / \mathrm{Yb}_{\mathrm{N}}$ & 18.2 & 10.6 & 1.8 & 3.6 \\
\hline
\end{tabular}




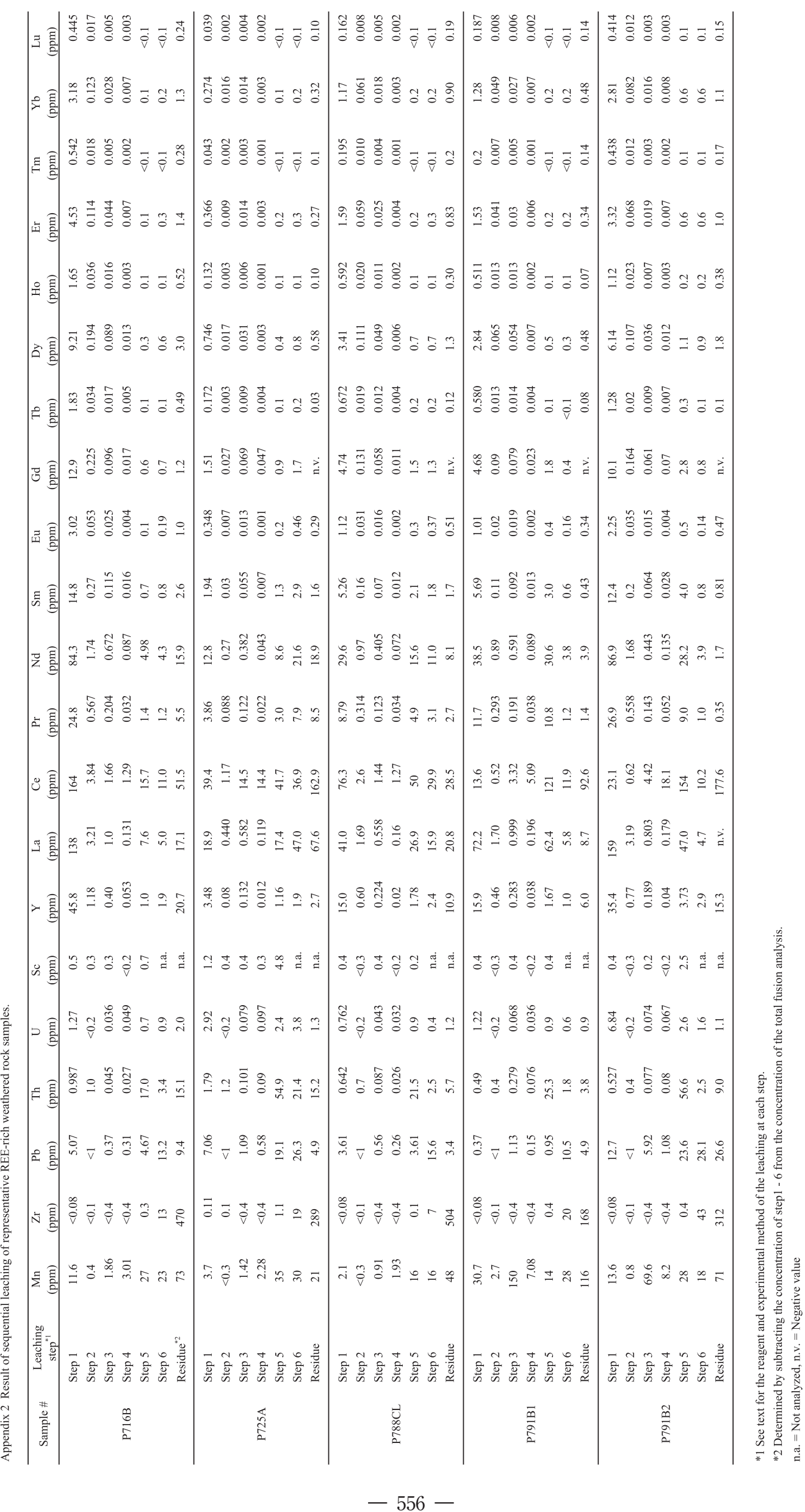




\begin{tabular}{|c|c|c|c|c|c|}
\hline 1 & $3: \frac{\infty}{0}$ & 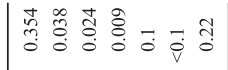 & 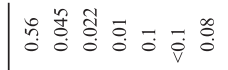 & 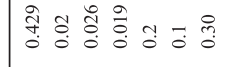 & 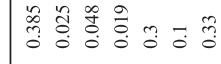 \\
\hline & 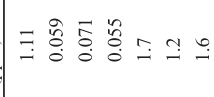 & 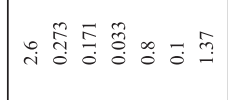 & 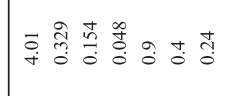 & 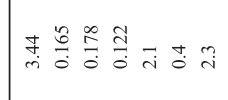 & 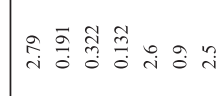 \\
\hline & 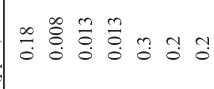 & 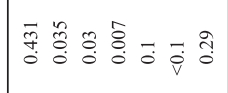 & 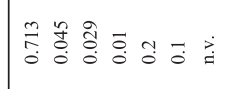 & 药 & 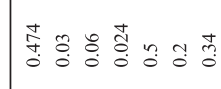 \\
\hline & 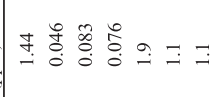 & 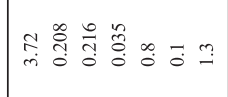 & 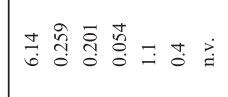 & 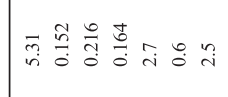 & 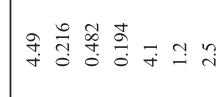 \\
\hline & 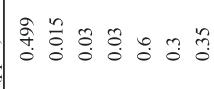 & 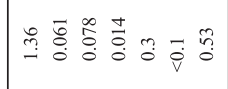 & 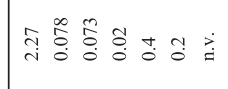 & 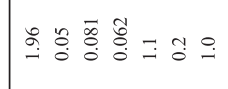 & 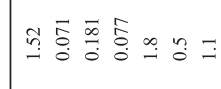 \\
\hline & 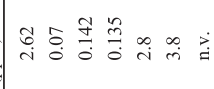 & 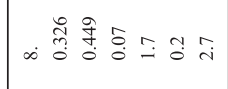 & 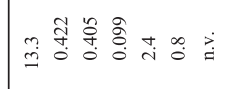 & 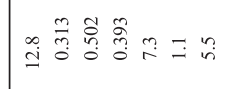 & 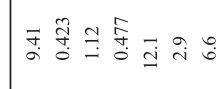 \\
\hline & 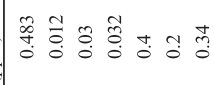 & 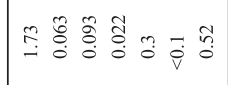 & 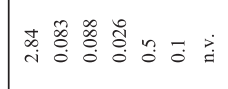 & 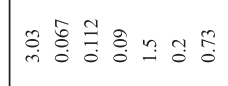 & 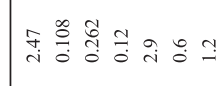 \\
\hline & 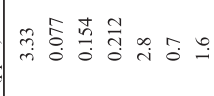 & 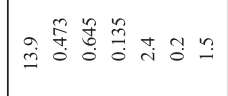 & 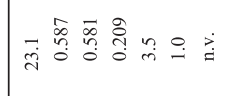 & 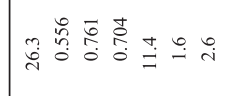 & 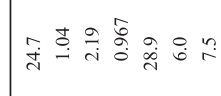 \\
\hline & 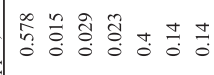 & 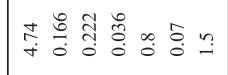 & 윰 & 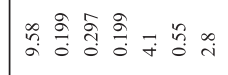 & 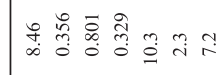 \\
\hline & $\bar{\sigma}$ & 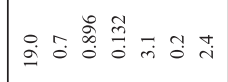 & 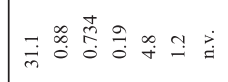 & 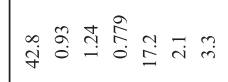 & 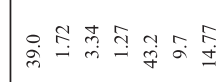 \\
\hline $\bar{z}$ & 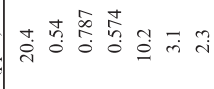 & 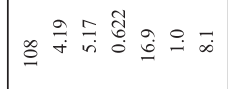 & 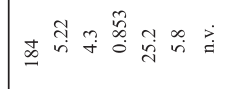 & 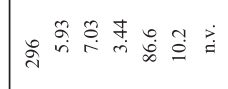 & 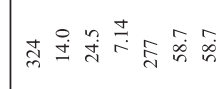 \\
\hline . & 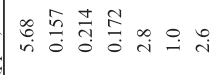 & 先 & 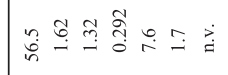 & 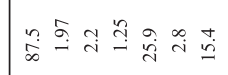 & 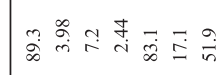 \\
\hline 8 & 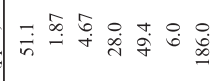 & तु & 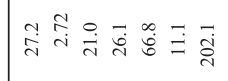 & 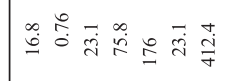 & 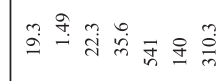 \\
\hline I & $\frac{1}{3} \stackrel{0}{\circ}$ & 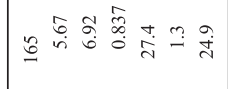 & 启 & 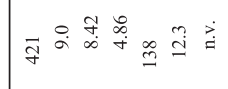 & 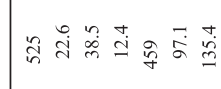 \\
\hline 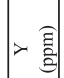 & 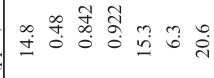 & 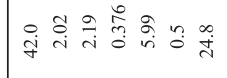 & 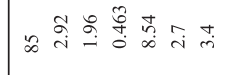 & 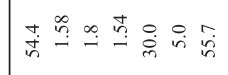 & 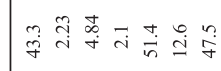 \\
\hline$\because$ & 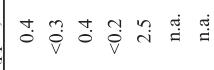 & 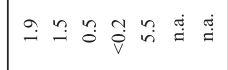 & 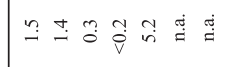 & 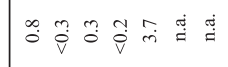 & 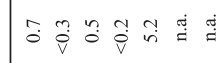 \\
\hline & 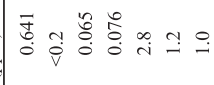 & 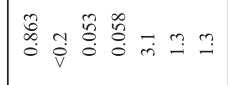 & 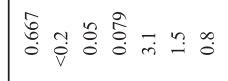 & 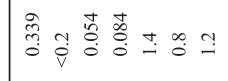 & 空 \\
\hline & $\underset{0}{\infty}$ & 考。 & 勇 & 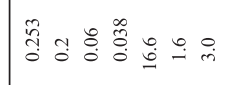 & 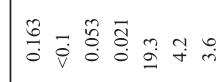 \\
\hline$\approx$ : & 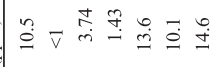 & 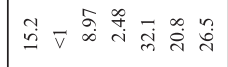 & 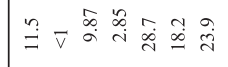 & 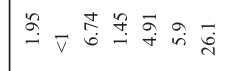 & 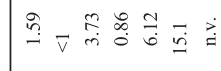 \\
\hline & 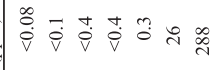 & 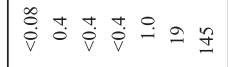 & 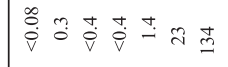 & 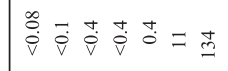 & 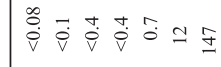 \\
\hline 兵 害 & 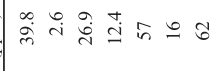 & 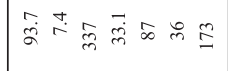 & 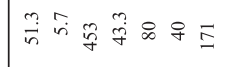 & 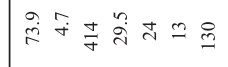 & 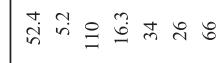 \\
\hline 总 & 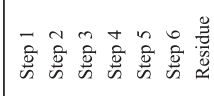 & 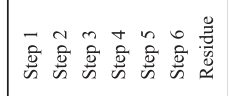 & 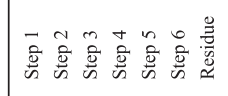 & 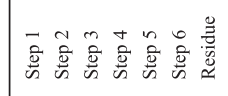 & 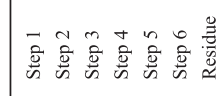 \\
\hline 帮 & 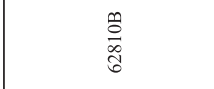 & $\overleftrightarrow{5}$ & $\vec{\nabla}$ & 愛 & 蒿 \\
\hline
\end{tabular}




\title{
ラオス中南部における花崗岩類とその風化殼中の希土類元素の濃集 \\ 実松健造 ${ }^{1}$ 村上浩康 ${ }^{1} \cdot$ 渡辺 寧 $^{1} \cdot$ Sixomxeun Duangsurigna $\cdot$ Siphandone Vilayhack ${ }^{2}$ \\ 要 旨
}

\begin{abstract}
イオン吸着型希土類鉱化作用の資源ポテンシャルを評価することを目的として、ラオス中南部における花崗岩類とそ の風化殼の地球化学的特徵を本稿に打いて報告する。調査地域の花崗岩類は主に黒雲母土普通角閃石花崗閃緑岩打よび 花崗岩であり、総希土類含有量は低ないし中程度 (36-339 ppm) である。これらの花崗岩類は中国南部や西南日本の重 希土類に富む花崗岩に比べると軽希土類に富み重希土類に乏しい。この重希土類の濃集における違いは花崗岩としてマ グマの分化が十分でなかったことに起因すると考えられる。花崗岩類の風化殼は全体的に発達しており、カオリンやイ ライトに富む。風化殼は上部から下部に向かって $\mathrm{A} 、 \mathrm{~B} 、 \mathrm{C}$ 層に分類され、 $\mathrm{B}$ 層は原岩に比べて希土類に富むが、 $\mathrm{A}$ 層 と C 層は一般に希土類含有量が減少するかわずかに増加する程度である。比較的高い希土類含有量を示す風化殼はア タプー地区とサイソンブーン地区において確認される。地球化学データと段階溶出実験結果は、これらの風化款に抏い て希土類の濃集がイオン交換性粘土鉱物や希土類りン酸塩に起因すること、風化によって軽希土類に比べ重希土類が選 択的に粘土鉱物に吸着されていることを示唆する。
\end{abstract}

\footnotetext{
${ }^{1}$ 産業技術総合研究所地圈資源環境研究部門

こラオス人民民主共和国エネルギー鉱山省
} 